\title{
C-H Bond Activation Reactions in Ketones and Aldehydes Promoted by POP-Pincer Osmium and Ruthenium Complexes
}

\author{
Joaquín Alós, Miguel A. Esteruelas,* Montserrat Oliván, Enrique Oñate, and Pim Puylaert \\ Departamento de Química Inorgánica, Instituto de Síntesis Química y Catálisis Homogénea (ISQCH), Centro de Innovación \\ en Química Avanzada (ORFEO-CINQA), Universidad de Zaragoza - CSIC, 50009 Zaragoza, Spain \\ Supporting Information Placeholder
}

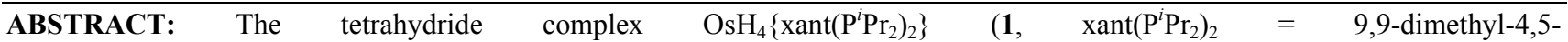
bis(diisopropylphosphino)xanthene) activates an ortho-C-H bond of benzophenone and acetophenone to give the osmaisobenzofuran derivatives $\mathrm{OsH}\left\{\kappa^{2}-\mathrm{C}, \mathrm{O}-\left[\mathrm{C}_{6} \mathrm{H}_{4} \mathrm{C}(\mathrm{R}) \mathrm{O}\right]\right\}\left\{\operatorname{xant}\left(\mathrm{P}^{i} \mathrm{Pr}_{2}\right)_{2}\right\}\left(\mathrm{R}=\mathrm{Ph}(\mathbf{2}), \mathrm{CH}_{3}(\mathbf{3})\right)$. The reaction of 1 with perdeuterated benzophenone leads to 2 partially protiated. The deuterium distribution in the latter suggests that the carbonyl group of the ketone traps the ortho-C-H addition product, which is the most disfavored from a kinetic point of view. The ruthenium counterpart $\mathrm{RuH}_{2}\left(\eta^{2}-\right.$ $\left.\mathrm{H}_{2}\right)\left\{\operatorname{xant}\left(\mathrm{P}^{i} \mathrm{Pr}_{2}\right)_{2}\right\}$, generated in situ from the tetrahydrideborate $\mathrm{RuH}\left(\eta^{2}-\mathrm{H}_{2} \mathrm{BH}_{2}\right)\left\{\operatorname{xant}\left(\mathrm{P}^{i} \mathrm{Pr}_{2}\right)_{2}\right\}$ (4) and 2-propanol, also activates benzophenone and acetophenone to afford the ruthenaisobenzofurans $\mathrm{RuH}\left\{\kappa^{2}-\mathrm{C}, \mathrm{O}-\left[\mathrm{C}_{6} \mathrm{H}_{4} \mathrm{C}(\mathrm{R}) \mathrm{O}\right]\right\}\left\{\operatorname{xant}\left(\mathrm{P}^{i} \mathrm{Pr}_{2}\right)_{2}\right\}\left(\mathrm{R}=\mathrm{Ph}_{(\mathbf{5}), \mathrm{CH}}\right.$ (6)). Both precursors favor the $\mathrm{C}-\mathrm{H}$ bond activation over the $\mathrm{C}-\mathrm{F}$ bond cleavage in fluorinated aromatic ketones. Thus, the fluorinated metalaisobenzofuran derivatives $\mathrm{OsH}\left\{\kappa^{2}-\mathrm{C}, \mathrm{O}-\left[\mathrm{C}_{6} \mathrm{H}_{3} \mathrm{FC}(\mathrm{Me}) \mathrm{O}\right]\right\}\left\{\mathrm{xant}\left(\mathrm{P}^{i} \mathrm{Pr}_{2}\right)_{2}\right\} \quad(7), \quad \mathrm{OsH}\left\{\kappa^{2}-\mathrm{C}, \mathrm{O}-\right.$ $\left.\left[\mathrm{C}_{6} \mathrm{H}_{4} \mathrm{C}\left(\mathrm{C}_{6} \mathrm{H}_{3} \mathrm{~F}_{2}\right) \mathrm{O}\right]\right\}\left\{\operatorname{xant}\left(\mathrm{P}^{i} \mathrm{Pr}_{2}\right)_{2}\right\}(8)$, and $\mathrm{RuH}\left\{\kappa^{2}-\mathrm{C}, \mathrm{O}-\left[\mathrm{C}_{6} \mathrm{H}_{3} \mathrm{FC}(\mathrm{Me}) \mathrm{O}\right]\right\}\left\{\operatorname{xant}\left(\mathrm{P}^{i} \mathrm{Pr}_{2}\right)_{2}\right\}$ (9) have been obtained from the ortho-C$\mathrm{H}$ bond activation of the corresponding substrates. Complex 1 also promotes the $\mathrm{C}_{\beta}-\mathrm{H}$ bond activation of benzylidenacetone and methyl vinyl ketone to afford the osmafurans $\mathrm{OsH}\left\{\kappa^{2}-\mathrm{C}, \mathrm{O}-[\mathrm{C}(\mathrm{R}) \mathrm{CHC}(\mathrm{Me}) \mathrm{O}]\right\}\left\{\operatorname{xant}\left(\mathrm{P}^{i} \mathrm{Pr}_{2}\right)_{2}\right\}(\mathrm{R}=\mathrm{Ph}(\mathbf{1 0}), \mathrm{H}(\mathbf{1 1}))$. The ruthenafuran counterparts $\mathrm{RuH}\left\{\kappa^{2}-\mathrm{C}, \mathrm{O}-[\mathrm{C}(\mathrm{R}) \mathrm{CHC}(\mathrm{Me}) \mathrm{O}]\right\}\left\{\operatorname{xant}\left(\mathrm{P}^{i} \mathrm{Pr}_{2}\right)_{2}\right\}(\mathrm{R}=\mathrm{Ph}(\mathbf{1 2}), \mathrm{H}(\mathbf{1 3}))$ were similarly generated by using 4 in the presence of 2-propanol. The analogous reactions with benzylidenacetophenone yield mixtures of OsH $\left\{\kappa^{2}-\mathrm{C}, \mathrm{O}-\right.$ $\left.\left[\mathrm{C}_{6} \mathrm{H}_{4} \mathrm{C}(\mathrm{CH}=\mathrm{CHPh}) \mathrm{O}\right]\right\}\left\{\operatorname{xant}\left(\mathrm{P}^{i} \mathrm{Pr}_{2}\right)_{2}\right\} \quad(\mathbf{1 4}) \quad$ and $\mathrm{OsH}\left\{\kappa^{2}-\mathrm{C}, \mathrm{O}-[\mathrm{C}(\mathrm{Ph}) \mathrm{CHC}(\mathrm{Ph}) \mathrm{O}]\right\}\left\{\mathrm{xant}\left(\mathrm{P}^{i} \mathrm{Pr}_{2}\right)_{2}\right\} \quad(\mathbf{1 5}), \quad$ and $\quad \mathrm{RuH}\left\{\kappa^{2}-\mathrm{C}, \mathrm{O}-\right.$ $\left.\left[\mathrm{C}_{6} \mathrm{H}_{4} \mathrm{C}(\mathrm{CH}=\mathrm{CHPh}) \mathrm{O}\right]\right\}\left\{\operatorname{xant}\left(\mathrm{P}^{i} \mathrm{Pr}_{2}\right)_{2}\right\}(\mathbf{1 6})$ and $\mathrm{RuH}\left\{\kappa^{2}-\mathrm{C}, \mathrm{O}-[\mathrm{C}(\mathrm{Ph}) \mathrm{CHC}(\mathrm{Ph}) \mathrm{O}]\right\}\left\{\operatorname{xant}\left(\mathrm{P}^{i} \mathrm{Pr}_{2}\right)_{2}\right\}$ (17). While the formation of the osmaisobenzofuran $\mathbf{1 4}$ is slightly favored with regard to that of $\mathbf{1 5}$, no preference is observed for ruthenium. In contrast, both precursors favor $\mathrm{OC}-\mathrm{H}$ activation over the cleavage of an ortho-C-H bond in aromatic aldehydes. Thus, their reactions with benzaldehyde yield $\mathrm{MH}(\mathrm{Ph})(\mathrm{CO})\left\{\operatorname{xant}\left(\mathrm{P}^{i} \mathrm{Pr}_{2}\right)_{2}\right\} \quad(\mathrm{M}=\mathrm{Os}(\mathbf{1 8}), \mathrm{Ru}(\mathbf{1 9}))$. The decarbonylation of the substrate is also observed with $\alpha, \beta$ unsaturated aldehydes. Thus, the reaction of 1 with 1-cyclohexene-1-carboxaldehyde gives $\mathrm{OsH}\left(\mathrm{C}_{6} \mathrm{H}_{9}\right)(\mathrm{CO})\left\{\operatorname{xant}\left(\mathrm{P}^{i} \mathrm{Pr}_{2}\right)_{2}\right\}(\mathbf{2 0})$. Decarbonylation and dehydrogenation of the aldehyde to form the trans-dihydride $\mathrm{OsH}_{2}(\mathrm{CO})\left\{\operatorname{xant}\left(\mathrm{P}^{i} \operatorname{Pr}_{2}\right)_{2}\right\}(\mathbf{2 1})$ take place with cyclohexane carboxaldehyde.
\end{abstract}

\section{INTRODUCTION}

The $\mathrm{C}-\mathrm{H}$ bond activation reactions promoted by transition metal complexes, which are omnipresent in organometallics, ${ }^{1}$ have a broad value in the current chemistry due to their connection with the functionalization of inert $\mathrm{C}-\mathrm{H}$ bonds ${ }^{2}$ and as an intermediate steps in the preparation of new materials. ${ }^{3} \mathrm{~A}$ major goal is to control the selectivity of the process when C$\mathrm{H}$ bonds of similar dissociation energies are present in the same substrate. One strategy is using a pre-existing functional group, which being well positioned in the molecule, facilitates the desired $\mathrm{C}-\mathrm{H}$ bond cleavage. ${ }^{4}$ From a catalytic point of view, carbonyl groups have advantages over pyridines, oxazolines, sulphides, or phosphines, among others. ${ }^{5}$ The weakly coordinating power of the carbonyl group reduces the stability of the resulting cyclometalated products, decreasing the activation energy of subsequent reactions. Thus, for instance, reactions involving ketones such as the additions of ortho-C-H bonds to olefins, alkynes, $\mathrm{CO} /$ olefins $^{6}$ and the ortho-arylations with arylbromides and arylboronates have received great attention. ${ }^{7}$

Also, we have been actively interested in the $\mathrm{C}-\mathrm{H}$ bond activation of ketones and aldehydes for a long time. Thus, as a part of our work in $\mathrm{C}-\mathrm{H}$ bond activation chemistry, ${ }^{8}$ we have reported on $\mathrm{C}-\mathrm{H}$ bond activation of cycloalkyl, aromatic, and $\alpha, \beta$-unsaturated ketones, ${ }^{9}$ and aldehydes ${ }^{10}$ promoted by osmium-polyhydride complexes containing the monodentate triisopropylphosphine ligand, including the saturated $\mathrm{d}^{2}$ hexahydride $\mathrm{OsH}_{6}\left(\mathrm{P}^{i} \mathrm{Pr}_{3}\right)_{2}$ (Scheme 1). The thermal activation of the latter involves the release of molecular hydrogen. The resulting $\mathrm{OsH}_{4}\left(\mathrm{P}^{i} \mathrm{Pr}_{3}\right)_{2}$ species has been trapped with pyridines and characterized as the corresponding tetrahydride compounds $\mathrm{OsH}_{4}($ pyridine- $\mathrm{R})\left(\mathrm{P}^{i} \mathrm{Pr}_{3}\right)_{2}$. ${ }^{11}$ The $\mathrm{C}-\mathrm{H}$ bond cleavage has in general high activation energy and therefore requires high temperatures and long times. In the search for more robust metal precursors, and at the same time more rigid, than those based on trans-M( $\left(\mathrm{P}^{i} \mathrm{Pr}_{3}\right)_{2}$ metal fragments, five years ago, we initiated a research program centered on pincer moieties-M(POP) $\quad(\mathrm{M}=\mathrm{Ru}, \quad \mathrm{Os}, \quad \mathrm{Rh}, \quad \mathrm{Ir} ; \quad \mathrm{POP}=4,6-$ 
bis(diisopropylphosphino)dibenzofuran $\quad\left(\mathrm{dbf}\left(\mathrm{P}^{i} \operatorname{Pr}_{2}\right)_{2}\right), \quad 9,9-$ dimethyl-4,5-bis(diisopropylphosphino)xanthene

(xant $\left.\left.\left(\mathrm{P}^{i} \mathrm{Pr}_{2}\right)_{2}\right)\right) .{ }^{12}$ Recently, we have described the preparation of the tetrahydride derivative $\mathrm{OsH}_{4}\left\{\operatorname{xant}\left(\mathrm{P}^{i} \mathrm{Pr}_{2}\right)_{2}\right\},{ }^{12 \mathrm{~d}}$ as a part of the results of this program, which is a rigid counterpart of the previous species $\mathrm{OsH}_{4}($ pyridine- $\mathrm{R})\left(\mathrm{P}^{i} \mathrm{Pr}_{3}\right)_{2}$. In spite of its saturated character, the hemilabile properties of the central oxygen atom of the diphosphine ${ }^{13}$ prompted us to study the ability of $\mathrm{OsH}_{4}\left\{\operatorname{xant}\left(\mathrm{P}^{i} \mathrm{Pr}_{2}\right)_{2}\right\}$ for promoting $\mathrm{C}-\mathrm{H}$ bond activation of aromatic, fluorinated aromatic, and $\alpha, \beta$-unsaturated ketones, and aldehydes. Because there are marked differences between the chemistries of osmium and ruthenium, ${ }^{14}$ including those of the M(POP) fragments, ${ }^{12 \mathrm{f}}$ the ability of the counterpart pincer ruthenium compound $\mathrm{RuH}_{2}\left(\eta^{2}-\mathrm{H}_{2}\right)\left\{\operatorname{xant}\left(\mathrm{P}^{i} \mathrm{Pr}_{2}\right)_{2}\right\}$ is also studied in parallel, for comparative purposes.

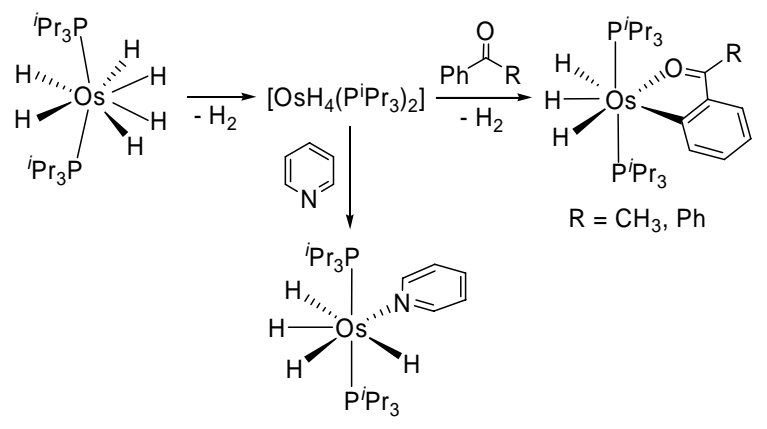

Scheme 1

The chemistry of the pincer osmium complexes has received scarce attention ${ }^{15}$ in comparison with that of the rest of platinum group metals. As a consequence, only a few systems have proved to promote the $\mathrm{C}-\mathrm{H}$ cleavage, ${ }^{16}$ although interesting stoichiometric and catalytic transformations involving the activation of $\mathrm{C}-\mathrm{H}$ bonds have been performed with other pincer transition metal compounds. ${ }^{17}$ In this paper, we report the first study on the $\mathrm{C}-\mathrm{H}$ bond activation of ketones and aldehydes promoted by a pincer osmium complex and the systematic comparison of each reaction with that performed using the ruthenium counterpart.

\section{RESULTS AND DISCUSSION}

1. Aromatic Ketones. Treatment of toluene solutions of the tetrahydride-osmium(IV) complex $\mathrm{OsH}_{4}\left\{\operatorname{xant}\left(\mathrm{P}^{i} \mathrm{Pr}_{2}\right)_{2}\right\} \quad$ (1) with 1.0 equiv of benzophenone and acetophenone, under reflux, for $12 \mathrm{~h}$ leads to the osmium(II) derivatives $\mathrm{OsH}\left\{\kappa^{2}-\right.$ $\left.\mathrm{C}, \mathrm{O}-\left[\mathrm{C}_{6} \mathrm{H}_{4} \mathrm{C}(\mathrm{R}) \mathrm{O}\right]\right\}\left\{\operatorname{xant}\left(\mathrm{P}^{i} \mathrm{Pr}_{2}\right)_{2}\right\}\left(\mathrm{R}=\mathrm{Ph}(\mathbf{2}), \mathrm{CH}_{3}(3)\right)$, as a result of the release of two hydrogen molecules and the selective ortho-C-H bond activation of the ketones. These compounds were isolated as purple (2) and dark red (3) solids in $73 \%$ and $69 \%$ yield, respectively, according to eq 1 .

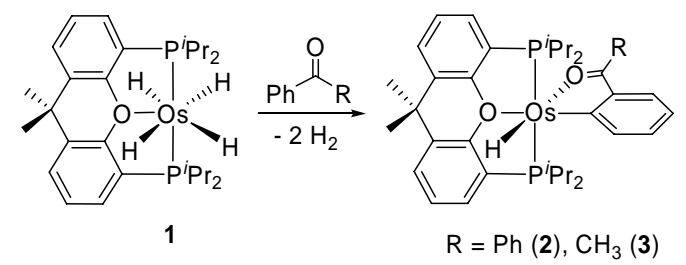

Complex 2 was characterized by X-ray diffraction analysis. The structure (Figure 1) proves the cleavage of the ortho-C-H bond of the substrate. As expected for the mer-coordination of the pincer, the Os $\left\{\operatorname{xant}\left(\mathrm{P}^{i} \mathrm{Pr}_{2}\right)_{2}\right\}$ skeleton is T-shaped with the osmium atom situated in the common vertex and $\mathrm{P}(1)$-Os-
$\mathrm{P}(2), \mathrm{P}(1)-\mathrm{Os}-\mathrm{O}(2)$, and $\mathrm{P}(2)-\mathrm{Os}-\mathrm{O}(2)$ angles of $153.28(5)^{\circ}$, $79.84(9)^{\circ}$ and $80.24(9)^{\circ}$, respectively. Thus, the coordination geometry around the metal center can be described as a distorted octahedron with the orthometalated ketone, which acts with a bite angle of $77.33(19)^{\circ}$, placed in the perpendicular plane to the P-Os-P direction along with the hydride ligand trans to the carbonyl oxygen atom $(\mathrm{O}(1)-\mathrm{Os}-\mathrm{H}(01)=$ $\left.167.8(19)^{\circ}\right)$ and the oxygen atom of the diphosphine trans to the metalated carbon atom $\left(\mathrm{O}(2)-\mathrm{Os}-\mathrm{C}(1)=173.69(18)^{\circ}\right)$. The Os-O(1) and Os-C(1) bond lengths of 2.190(4) and 1.975(5) $\AA$, respectively, compare well with the distances found in other five-membered osmacycles resulting from related $\mathrm{C}-\mathrm{H}$ bond activations. ${ }^{9}$

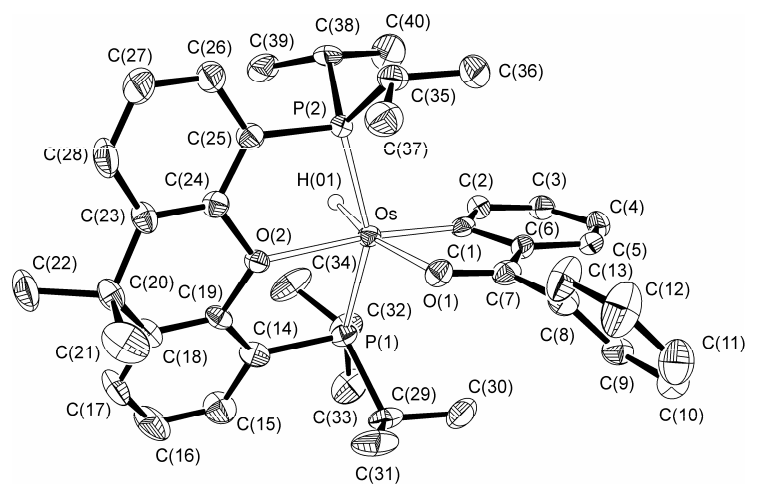

Figure 1. ORTEP diagram of complex 2 (50\% probability ellipsoids). Hydrogen atoms (except the hydride) are omitted for clarity. Selected bond lengths $(\AA)$ and angles $\left({ }^{\circ}\right)$ : Os-P $(1)=$ $2.2745(14)$, Os- $\mathrm{P}(2)=2.2821(14)$, Os-O $(1)=2.190(4)$, Os-O $(2)=$ $2.328(4)$, Os- $\mathrm{C}(1)=1.975(5), \mathrm{Os}-\mathrm{H}(01)=1.584(10), \mathrm{O}(1)-\mathrm{C}(7)=$ $1.275(6), \mathrm{C}(1)-\mathrm{C}(6)=1.429(8), \mathrm{C}(6)-\mathrm{C}(7)=1.435(8) ; \mathrm{P}(1)$-Os$\mathrm{P}(2)=153.28(5), \mathrm{P}(1)-\mathrm{Os}-\mathrm{O}(2)=79.84(9), \mathrm{P}(2)-\mathrm{Os}-\mathrm{O}(2)=$ 80.24(9), O(1)-Os-C(1) = 77.33(19), O(2)-Os-C(1) = 173.69(18), $\mathrm{O}(1)-\mathrm{Os}-\mathrm{H}(01)=167.8(19)$.

The ${ }^{1} \mathrm{H},{ }^{13} \mathrm{C}\left\{{ }^{1} \mathrm{H}\right\}$, and ${ }^{31} \mathrm{P}\left\{{ }^{1} \mathrm{H}\right\}$ NMR spectra of $\mathbf{2}$ and $\mathbf{3}$, in benzene- $d_{6}$, at room temperature are consistent with the structure shown in Figure 1. In agreement with the presence of a hydride ligand in the compounds, their ${ }^{1} \mathrm{H}$ NMR spectra contain a triplet, with a H-P coupling constant of about $23 \mathrm{~Hz}$, at $17.03 \mathrm{ppm}$ for $\mathbf{2}$ and at $-18.01 \mathrm{ppm}$ for $\mathbf{3}$. In the ${ }^{13} \mathrm{C}\left\{{ }^{1} \mathrm{H}\right\} \mathrm{NMR}$ spectra, the most noticeable feature is the resonance corresponding to the metalated carbon atom, which is observed at 187.4 ppm for $\mathbf{2}$ and at $184.3 \mathrm{ppm}$ for $\mathbf{3}$ as a triplet with a C-P coupling constant of about $4 \mathrm{~Hz}$. The ${ }^{31} \mathrm{P}\left\{{ }^{1} \mathrm{H}\right\}$ NMR spectra show a singlet at $47.0 \mathrm{ppm}$ for $\mathbf{2}$ and at $46.3 \mathrm{ppm}$ for $\mathbf{3}$, as expected for equivalent $\mathrm{P}^{i} \mathrm{Pr}_{2}$ groups.

Matsubara and Morokuma have proposed on the basis of DFT calculations using $\mathrm{PH}_{3}$ and benzaldehyde as models of phosphine and substrate, respectively, that the ortho-C-H bond activation of aromatic ketones promoted by Murai's catalyst involves the initial formyl coordination to the metal center followed by the cleavage of the closest ortho-C-H bond. ${ }^{18}$ In contrast to this proposal, Goldman has demonstrated that the coordinating group does not direct the $\mathrm{C}-\mathrm{H}$ bond addition to $\operatorname{Ir}(\mathrm{PCP})$ skeletons. To the contrary, the functional group is found to actually prevent the $\mathrm{C}-\mathrm{H}$ addition from a kinetic point of view. However, after the $\mathrm{C}-\mathrm{H}$ bond cleavage, the coordinating group acts to trap the ortho-C-H addition product afford- 
ing orthometalated compounds. ${ }^{17 a}$ To gain insight into the origin of the selectivity of the ortho-C-H bond activation in our case, we carried out the reaction of 1 with perdeuterated benzophenone. Under the same conditions at those employed with the protiated substrate, the reaction led to the compound with the orthometalated ketone almost completely protiated in positions distal to the carbonyl group, whereas it keeps about 0.4 deuterium atoms at each one of the ortho positions to the carbonyl group and about 0.2 deuterium atoms at the ortho position to the metal center. This result reveals that the $\mathrm{C}-\mathrm{H}$ bond activation of the reaction solvent, toluene, is kinetically favored with regard to that of the ketone, fully agrees with Goldman's observations, and demonstrates that the selectivity of the ortho-C-H bond activation of aromatic ketones is thermodynamic in origin while the activations of the $\mathrm{C}-\mathrm{H}$ bonds in meta and para positions are kinetically preferred.

Complex $\mathbf{1}$ is relatively stable under the reaction conditions in the absence of substrate. Thus, it is recovered after $24 \mathrm{~h}$ under reflux whereas under hydrogen atmosphere it is in equilibrium with the previously described hexahydride $\mathrm{OsH}_{6}\left\{\operatorname{xant}\left(\mathrm{P}^{i} \mathrm{Pr}_{2}\right)_{2}\right\}$, containing a bidentate $\kappa^{2}$-PP diphosphine. 12d This is consistent with the behavior of complexes $\mathrm{OsH}_{4}($ pyridine- $\mathrm{R})\left(\mathrm{P}^{i} \mathrm{Pr}_{3}\right)_{2}$, which in the presence of added pyridine exchange the coordinated heterocycle by the free one. $^{11}$ These experimental observations suggest that the $\mathrm{C}-\mathrm{H}$ bond activation takes place through Os(IV) species, including $\mathrm{OsH}_{5}$-intermediates, related to those formed in the $\mathrm{OsH}_{6}\left(\mathrm{P}^{\mathrm{i}} \mathrm{Pr}_{3}\right)_{2}$-mediated $\mathrm{C}-\mathrm{H}$ bond activation of imidazolium salts. ${ }^{19}$ These (POP)OsH $\mathrm{O}_{5}$ intermediates are transformed into POP-counterparts of complexes $\mathrm{OsH}_{3}\left\{\kappa^{2}-\mathrm{C}, \mathrm{O}-\right.$ $\left.\left[\mathrm{C}_{6} \mathrm{H}_{4} \mathrm{C}(\mathrm{R}) \mathrm{O}\right]\right\}\left(\mathrm{P}^{i} \mathrm{Pr}_{3}\right)_{2}$ shown in Scheme 1 .

Osmium is more reducing than ruthenium. As a consequence, the $\mathrm{Ru}\left\{\operatorname{xant}\left(\mathrm{P}^{i} \mathrm{Pr}_{2}\right)_{2}\right\}$ metal fragment avoids the oxidation state four. Thus, osmium $d^{4}$-polyhydrides are $d^{6}$ dihydrogen species in the ruthenium chemistry, which require different synthetic procedures from those of osmium for their preparation. ${ }^{12}$ The ruthenium counterpart of $\mathbf{1}$ is the $\mathrm{d}^{6}$ dihydride-dihydrogen derivative $\mathrm{RuH}_{2}\left(\eta^{2}-\mathrm{H}_{2}\right)\left\{\operatorname{xant}\left(\mathrm{P}^{i} \mathrm{Pr}_{2}\right)_{2}\right\}$ (A, in Scheme 2), which rapidly loses the coordinated hydrogen molecule under an argon atmosphere to afford the dihydride $\mathrm{RuH}_{2}\left\{\operatorname{xant}\left(\mathrm{P}^{i} \mathrm{Pr}_{2}\right)_{2}\right\}$ (B). Both $\mathbf{A}$ and $\mathbf{B}$ are not handy compounds from an experimental point of view. However, they can be generated in situ by treatment of the hydridetetrahydrideborate complex $\mathrm{RuH}\left(\eta^{2}-\mathrm{H}_{2} \mathrm{BH}_{2}\right)\left\{\operatorname{xant}\left(\mathrm{P}^{i} \mathrm{Pr}_{2}\right)_{2}\right\}$ (4) with 2-propanol. So, in order to compare the Os $\left\{\operatorname{xant}\left(\mathrm{P}^{i} \mathrm{Pr}_{2}\right)_{2}\right\}$ and $\mathrm{Ru}\left\{\operatorname{xant}\left(\mathrm{P}^{i} \mathrm{Pr}_{2}\right)_{2}\right\}$ metal fragments, we performed reactions analogous to those shown in eq 1 starting from 4 and 2propanol. Because the dihydride $\mathbf{B}$ reduces ketones, 2 equiv of substrate were used. Thus, treatment of toluene solutions of $\mathbf{4}$ with 2 equiv of benzophenone and acetophenone, in the presence of 1.0 equiv of 2 -propanol, at $80^{\circ} \mathrm{C}$, for $6 \mathrm{~h}$ gives rise to 1.0 equiv of the corresponding alcohol and to the complexes $\mathrm{RuH}\left\{\kappa^{2}-\mathrm{C}, \mathrm{O}-\left[\mathrm{C}_{6} \mathrm{H}_{4} \mathrm{C}(\mathrm{R}) \mathrm{O}\right]\right\}\left\{\operatorname{xant}\left(\mathrm{P}^{i} \mathrm{Pr}_{2}\right)_{2}\right\} \quad\left(\mathrm{R}=\mathrm{Ph}(\mathbf{5}), \mathrm{CH}_{3}\right.$ (6)), which were isolated as purple (5) and dark red (6) solids in $61 \%$ and $52 \%$ yield, respectively.

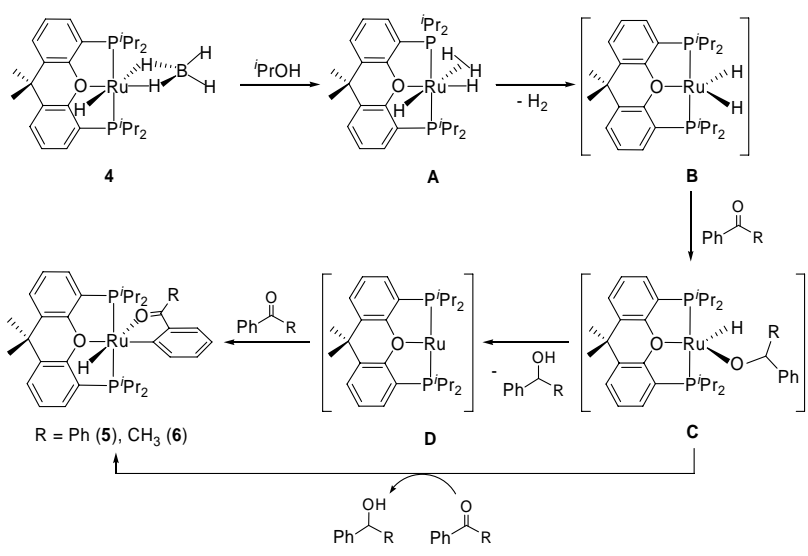

Scheme 2

The ${ }^{1} \mathrm{H},{ }^{13} \mathrm{C}\left\{{ }^{1} \mathrm{H}\right\}$, and ${ }^{31} \mathrm{P}\left\{{ }^{1} \mathrm{H}\right\}$ NMR spectra of 5 and $\mathbf{6}$, in benzene- $d_{6}$, at room temperature agree well with those of 2 and $\mathbf{3}$ and strongly support the structures shown in Scheme 2. In the ${ }^{1} \mathrm{H}$ NMR spectra, the hydride resonance appears at $15.42 \mathrm{ppm}$ for $\mathbf{5}$ and at $-16.36 \mathrm{ppm}$ for $\mathbf{6}$, as a triplet with a $\mathrm{H}$ $\mathrm{P}$ coupling constant between 26 and $27 \mathrm{~Hz}$. In the ${ }^{13} \mathrm{C}\left\{{ }^{1} \mathrm{H}\right\}$ NMR spectra, the metalated carbon atom displays a triplet, with a C-P coupling constant of about $8 \mathrm{~Hz}$, at $212.4 \mathrm{ppm}$ for 5 and at $209.0 \mathrm{ppm}$ for $\mathbf{6}$. It should be pointed out that these resonances are shifted about $25 \mathrm{ppm}$ to lower field with regard to those of the osmium counterparts, suggesting that the metalaisobenzofuran character of the fused rings is higher for ruthenium than for osmium. A singlet at about $62 \mathrm{ppm}$ in the ${ }^{31} \mathrm{P}\left\{{ }^{1} \mathrm{H}\right\}$ NMR spectra is also a characteristic feature of these compounds.

The reduction of the ketone during the reaction could occur via intermediate $\mathbf{C}$, resulting from the insertion of the $\mathrm{C}=\mathrm{O}$ double bond into one of Ru-H bonds of $\mathbf{B}$ (Scheme 2). Thus, the elimination of alcohol should afford the 14 electrons valence ruthenium(0) intermediate $\operatorname{Ru}\left\{\operatorname{xant}\left(\mathrm{P}^{i} \mathrm{Pr}_{2}\right)_{2}\right\}$ (D), which could undergo the ortho- $\mathrm{C}-\mathrm{H}$ bond oxidative addition of a second molecule of ketone to yield $\mathbf{5}$ and $\mathbf{6}$. An alternative pathway would involve the direct heterolytic $\mathrm{C}-\mathrm{H}$ bond activation of the second ketone molecule promoted by $\mathbf{C}$, which uses the alkoxide ligand as a base. The participation of both mechanisms is consistent with the presence of about 0.5 deuterium atoms at the hydride position of the product resulting from the reaction of $\mathbf{4}$ with perdeuterated benzophenone. Furthermore, although the metalated ketone is mainly deuterated, it contains 0.6 hydrogen atoms at the ortho-position with regard to the metal center (meta with regard to the carbonyl group) and about 0.2 hydrogen atoms at each ortho-position with regard to the carbonyl group. This indicates that the activation of the meta-C-H bond of the ketone is kinetically favored over the ortho-C-H bond, and suggests that the ortho$\mathrm{CH}$ bond cleavage is not chelated assisted.

2. Fluorinated Aromatic Ketones. The activations of $\mathrm{C}-\mathrm{H}$ and $\mathrm{C}-\mathrm{F}$ bonds are competitive processes, when both bonds coexist in the same molecule. In general, the $\mathrm{C}-\mathrm{H}$ bond activation is a stronger competitor in a kinetic sense, ${ }^{20}$ whereas the $\mathrm{C}$-F cleavage is thermodynamically more favored, in particular when $\mathrm{HF}$ is formed. ${ }^{21}$ We have previously observed that the hexahydride complex $\mathrm{OsH}_{6}\left(\mathrm{P}^{i} \mathrm{Pr}_{3}\right)_{2}$ activates not only ortho-C$\mathrm{H}$ bonds of aromatic ketones but also C-F bonds. ${ }^{9 \mathrm{a}}$ The ortho$\mathrm{C}-\mathrm{H}$ bond activation is preferred over the ortho-C-F bond activation in ketones containing only one aromatic ring. How- 
ever, the ortho-C-F bond activation is preferred over the ortho-C-H bond activation for ketones with both diorthofluorinated and diortho-protiated aromatic groups. In contrast to $\mathrm{Os}\left(\mathrm{P}^{i} \mathrm{Pr}_{3}\right)_{2}$, the $\mathrm{Os}\left\{\operatorname{xant}\left(\mathrm{P}^{i} \mathrm{Pr}_{2}\right)_{2}\right\}$-mediated $\mathrm{C}-\mathrm{H}$ bond activation is preferred in both cases (Scheme 3). Treatment of toluene solutions of 1 with 1.0 equiv of 2-fluoroacetophenone and 2,6-difluorobenzophenone, under reflux, for $14 \mathrm{~h}$ selectively leads to the corresponding $\mathrm{C}-\mathrm{H}$ bond activation products $\mathrm{OsH}\left\{\kappa^{2}-\mathrm{C}, \mathrm{O}-\left[\mathrm{C}_{6} \mathrm{H}_{3} \mathrm{FC}(\mathrm{Me}) \mathrm{O}\right]\right\}\left\{\operatorname{xant}\left(\mathrm{P}^{i} \mathrm{Pr}_{2}\right)_{2}\right\}$ (7) and $\mathrm{OsH}\left\{\kappa^{2}-\right.$ $\left.\mathrm{C}, \mathrm{O}-\left[\mathrm{C}_{6} \mathrm{H}_{4} \mathrm{C}\left(\mathrm{C}_{6} \mathrm{H}_{3} \mathrm{~F}_{2}\right) \mathrm{O}\right]\right\}\left\{\operatorname{xant}\left(\mathrm{P}^{i} \mathrm{Pr}_{2}\right)_{2}\right\} \quad(\mathbf{8})$, which were isolated as dark red and purple solids in $30 \%$ and $72 \%$ yield, respectively. Although the $\mathrm{M}-\mathrm{C}$ bond energies increase with the ortho-fluorine substitution, ${ }^{22}$ products resulting from the cleavage of a $\mathrm{C}-\mathrm{H}$ bond ortho to the fluorine substituents were also not observed. The behavior of $\mathbf{1}$ is as that of the trihydride-stannyl osmium(IV) complex $\mathrm{OsH}_{3}\left(\mathrm{SnPh}_{2} \mathrm{Cl}\right)\left\{\kappa^{3}-\mathrm{P}, \mathrm{C}, \mathrm{C}-\right.$ $\left.\left[{ }^{i} \mathrm{Pr}_{2} \mathrm{PC}(\mathrm{Me})=\mathrm{CH}_{2}\right]\right\}\left(\mathrm{P}^{i} \mathrm{Pr}_{3}\right)$, which reacts with 2fluoroacetophenone and 2,3,4,5,6-pentafluorobenzophenone to afford the respective ortho-C-H bond activation products. ${ }^{9 \mathrm{c}}$

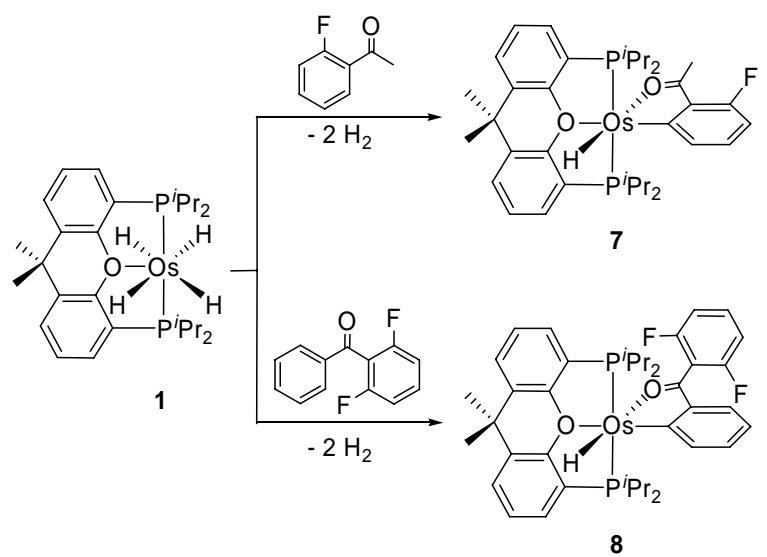

Scheme 3

The $\mathrm{C}-\mathrm{H}$ bond activation of the substrates is strongly supported by the ${ }^{1} \mathrm{H},{ }^{19} \mathrm{~F}\left\{{ }^{1} \mathrm{H}\right\},{ }^{13} \mathrm{C}\left\{{ }^{1} \mathrm{H}\right\}$, and ${ }^{31} \mathrm{P}\left\{{ }^{1} \mathrm{H}\right\}$ NMR spectra of the obtained solids, in benzene- $d_{6}$, at room temperature. In agreement with the presence of a hydride ligand in the reaction products, the ${ }^{1} \mathrm{H}$ NMR spectra show at -17.83 ppm for 7 and at $-17.33 \mathrm{ppm}$ for 8 a triplet with a H-P coupling constant between 22 and $24 \mathrm{~Hz}$, whereas the ${ }^{19} \mathrm{~F}\left\{{ }^{1} \mathrm{H}\right\}$ NMR spectra contain a singlet at $-113.4 \mathrm{ppm}$ for 7 and at $-109.2 \mathrm{ppm}$ for $\mathbf{8}$. In the ${ }^{13} \mathrm{C}\left\{{ }^{1} \mathrm{H}\right\}$ NMR spectrum of 7 , the metalated carbon atom displays at $188.5 \mathrm{ppm}$ a double triplet with C-F and C-P coupling constants of about $4 \mathrm{~Hz}$, whereas the related resonance of $\mathbf{8}$ is observed at $188.1 \mathrm{ppm}$ as a triplet with a C-P coupling constant of $3.7 \mathrm{~Hz}$. The ${ }^{31} \mathrm{P}\left\{{ }^{1} \mathrm{H}\right\}$ NMR spectra show a singlet at $46.2 \mathrm{ppm}$ for $\mathbf{7}$ and at $48.5 \mathrm{ppm}$ for $\mathbf{8}$.

The $\mathrm{Ru}\left\{\operatorname{xant}\left(\mathrm{P}^{i} \mathrm{Pr}_{2}\right)_{2}\right\}$ fragment also favors the $\mathrm{C}-\mathrm{H}$ bond activation over the $\mathrm{C}-\mathrm{F}$ bond cleavage. Treatment of toluene solutions of 4 with 2.0 equiv of 2 -fluoroacetophenone, in the presence of 1.0 equiv of 2-propanol, at $80^{\circ} \mathrm{C}$, for $6 \mathrm{~h}$ leads to the $\mathrm{C}-\mathrm{H}$ bond activation product $\mathrm{RuH}\left\{\kappa^{2}-\mathrm{C}, \mathrm{O}-\right.$ $\left.\left[\mathrm{C}_{6} \mathrm{H}_{3} \mathrm{FC}(\mathrm{Me}) \mathrm{O}\right]\right\}\left\{\operatorname{xant}\left(\mathrm{P}^{i} \mathrm{Pr}_{2}\right)_{2}\right\}$ (9), which was isolated as a red solid in $38 \%$ yield, according to eq 2 .

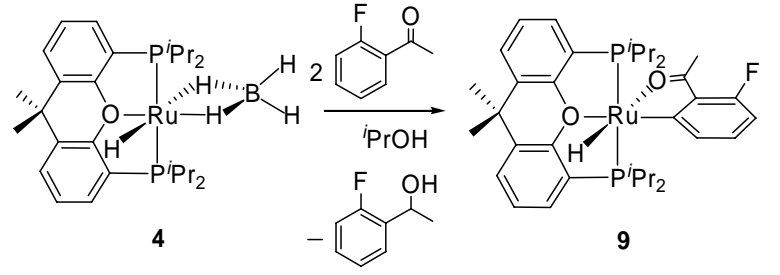

The ${ }^{1} \mathrm{H},{ }^{13} \mathrm{C}\left\{{ }^{1} \mathrm{H}\right\},{ }^{19} \mathrm{~F}\left\{{ }^{1} \mathrm{H}\right\}$, and ${ }^{31} \mathrm{P}\left\{{ }^{1} \mathrm{H}\right\}$ NMR spectra of 9 , in benzene- $d_{6}$, at room temperature agree well with those of the osmium counterpart 7 . In the ${ }^{1} \mathrm{H}$ NMR spectrum, the hydride resonance appears at $-16.11 \mathrm{ppm}$, as a triplet with a H-P coupling constant of $25.6 \mathrm{~Hz}$. In the ${ }^{13} \mathrm{C}\left\{{ }^{1} \mathrm{H}\right\}$ NMR spectrum, the metalated carbon atom displays a double triplet with $\mathrm{C}-\mathrm{F}$ and C-P coupling constants of 6.0 and $8.3 \mathrm{~Hz}$, respectively, at $213.7 \mathrm{ppm}$, i.e., shifted about $25 \mathrm{ppm}$ to lower field with regard to the metalated resonance of 7, in agreement with $\mathbf{5}$ and 6. Singlets at $-109.1 \mathrm{ppm}$ and $62.1 \mathrm{ppm}$ in the ${ }^{19} \mathrm{~F}\left\{{ }^{1} \mathrm{H}\right\}$ and ${ }^{31} \mathrm{P}\left\{{ }^{1} \mathrm{H}\right\}$ NMR spectra, respectively, are also characteristic features of this compound.

The behavior of $\mathbf{1}$ and $\mathbf{4}$ in these competitive reactions is in contrast to that observed by Zhang and Li for the iron complex $\mathrm{Fe}\left(\mathrm{PMe}_{3}\right)_{4}$ which reacts with 2,6-difluorobenzophenone to give an iron(II) derivative resulting from the C-F bond activation of two substrate molecules. ${ }^{23}$ Similarly, the cobalt precursor $\mathrm{CoMe}\left(\mathrm{PMe}_{3}\right)_{4}$ promotes the cleavage of a C-F bond of the same substrate. ${ }^{24}$

3. $\boldsymbol{\alpha}, \boldsymbol{\beta}$-Unsaturated Ketones. The insertion of alkenes into metal-hydride bonds to afford alkyl derivatives is one of the most typical reactions of transition-metal-hydride complexes and constitutes the key step for the catalytic hydrogenation of olefins. This reaction frequently competes with the addition of vinylic $\mathrm{C}-\mathrm{H}$ bonds to the metal center when the hydride complex is an unsaturated species. $\alpha, \beta$-Unsaturated ketones are organic molecules that could undergo both processes. ${ }^{25}$ Thus, in order to investigate the competition between them, for the reactions mediated by $\mathrm{Os}\left\{\operatorname{xant}\left(\mathrm{P}^{i} \mathrm{Pr}_{2}\right)_{2}\right\}$ and $\mathrm{Ru}\left\{\operatorname{xant}\left(\mathrm{P}^{i} \mathrm{Pr}_{2}\right)_{2}\right\}$ systems, we have extended the study on carbonyl derivatives to these substrates.

Treatment of toluene solutions of $\mathbf{1}$ with 1.0 equiv of benzylidenacetone and methyl vinyl ketone, under reflux, overnight leads to the hydride-osmafuran derivatives $\mathrm{OsH}\left\{\kappa^{2}-\mathrm{C}, \mathrm{O}-\right.$ $[\mathrm{C}(\mathrm{R}) \mathrm{CHC}(\mathrm{Me}) \mathrm{O}]\}\left\{\operatorname{xant}\left(\mathrm{P}^{i} \mathrm{Pr}_{2}\right)_{2}\right\}(\mathrm{R}=\mathrm{Ph}(\mathbf{1 0}), \mathrm{H}(\mathbf{1 1}))$, as a result of the $\mathrm{C}-\mathrm{H}$ bond activation of the substrates. Insertion products of the $\mathrm{C}-\mathrm{C}$ double bond into a Os-H bond were not detected during the reactions. Complexes 10 and 11 were isolated as dark green solids in 90\% (10) and 64\% (11) yield, according to eq 3 .

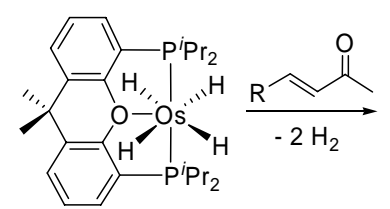

1

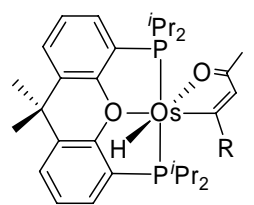

$\mathrm{R}=\mathrm{Ph}(\mathbf{1 0}), \mathrm{H}(11)$
Complex 10 was characterized by X-ray diffraction analysis. The structure, which proves the activation of the $\mathrm{C}_{\beta}-\mathrm{H}$ bond of the substrate, has two chemically equivalent but crystallographically independent molecules in the asymmetric unit. Figure 2 shows a drawing of one of them. In agreement with $\mathbf{2}$, the Os $\left\{\operatorname{xant}\left(\mathrm{P}^{i} \mathrm{Pr}_{2}\right)_{2}\right\}$ skeleton displays a mer coordination with 
$\mathrm{P}(1)-\mathrm{Os}(1)-\mathrm{P}(2), \mathrm{P}(1)-\mathrm{Os}(1)-\mathrm{O}(2)$, and $\mathrm{P}(2)-\mathrm{Os}(1)-\mathrm{O}(2)$ angles of $154.58(9)^{\circ}$ and $156.38(9)^{\circ}, 80.58(15)^{\circ}$ and $80.14(16)^{\circ}$, and $80.24(15)^{\circ}$ and $80.12(16)^{\circ}$, respectively. Thus, the coordination polyhedron around the osmium atom can be rationalized as a distorted octahedron with the oxygen atom of the diphosphine trans to the metalated carbon atom of the activated ketone $\left(\mathrm{O}(2)-\mathrm{Os}(1)-\mathrm{C}(1)=171.3(3)^{\circ}\right.$ and $\left.168.6(3)^{\circ}\right)$ and the hydride ligand trans to the oxygen atom $(\mathrm{O}(1)-\mathrm{Os}(1)-\mathrm{H}(01)=$ $175(3)^{\circ}$ and $\left.177(3)^{\circ}\right)$. The activated substrate certainly forms with the metal center an osmafuran ring. The Os(1)-C(1) bond lengths of 1.970(9) and 1.953(9) $\AA$ agree well with those expected for a derivative of this type where the resonance forms shown in Chart 1 should be taken into account to describe the bonding situation in the heterometalacycle. ${ }^{9 d-f, 25 b, 26}$ In accordance with this, the $\mathrm{C}(1)-\mathrm{C}(8)$ and $\mathrm{C}(8)-\mathrm{C}(9)$ distances of 1.419(14) and 1.444(14) $\AA$, and 1.377(14) and 1.380(14) $\AA$, respectively, are between those expected for single and double carbon-carbon bonds and indicate a very important contribution of the resonance form $\mathbf{b}$. The $\mathrm{Os}(1)-\mathrm{O}(1)$ and $\mathrm{O}(1)-\mathrm{C}(9)$ bond lengths of 2.164(7) and 2.152(7) $\AA$, and 1.282(11) and 1.281(12) $\AA$, respectively, also support the metalafuran character. $^{27}$

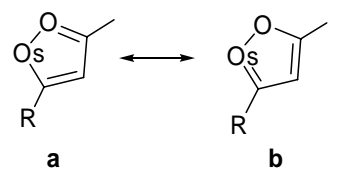

Chart 1

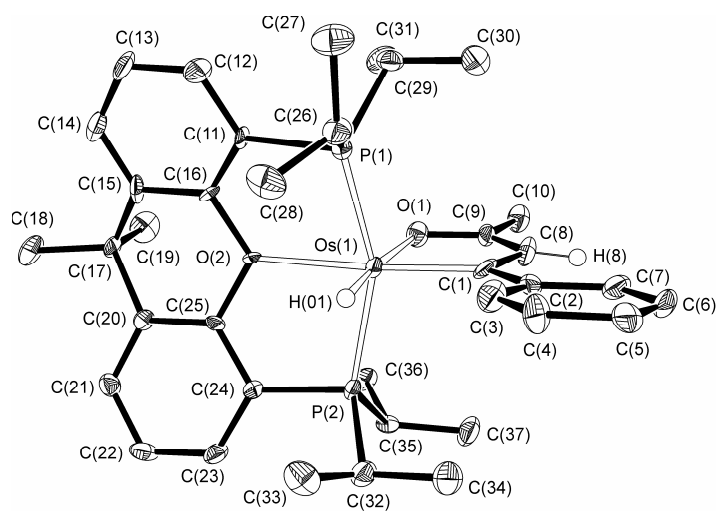

Figure 2. ORTEP diagram of complex 10 (50\% probability ellipsoids). Hydrogen atoms (except the hydride and $\mathrm{H}(8)$ ) are omitted for clarity. Selected bond lengths $(\AA)$ and angles $\left({ }^{\circ}\right)$ : Os(1)-P(1)= $2.286(2), 2.276(3), \mathrm{Os}(1)-\mathrm{P}(2)=2.287(2), 2.303(2), \mathrm{Os}(1)-\mathrm{O}(1)=$ $2.164(7), 2.152(7), \mathrm{Os}(1)-\mathrm{O}(2)=2.336(6), 2.312(6), \mathrm{Os}(1)-\mathrm{C}(1)=$ $1.970(9), 1.953(9), \mathrm{Os}(1)-\mathrm{H}(01)=1.583(10), 1.594(10), \mathrm{C}(1)-$ $\mathrm{C}(8)=1.419(14), 1.444(14), \mathrm{C}(8)-\mathrm{C}(9)=1.377(14), 1.380(14)$, $\mathrm{O}(1)-\mathrm{C}(9)=1.282(11), 1.281(12) ; \mathrm{P}(1)-\mathrm{Os}(1)-\mathrm{P}(2)=154.58(9)$, 156.38(9), $\mathrm{P}(1)-\mathrm{Os}(1)-\mathrm{O}(2)=80.58(15), 80.14(16), \mathrm{P}(2)-\mathrm{Os}(1)-$ $\mathrm{O}(2)=80.24(15), 80.12(16), \mathrm{O}(1)-\mathrm{Os}(1)-\mathrm{H}(01)=175(3), 177(3)$, $\mathrm{O}(2)-\mathrm{Os}(1)-\mathrm{C}(1)=171.3(3), 168.6(3), \mathrm{O}(1)-\mathrm{Os}(1)-\mathrm{C}(1)=79.3(3)$, $79.9(3)$.

The ${ }^{1} \mathrm{H},{ }^{13} \mathrm{C}\left\{{ }^{1} \mathrm{H}\right\}$, and ${ }^{31} \mathrm{P}\left\{{ }^{1} \mathrm{H}\right\}$ NMR spectra of $\mathbf{1 0}$ and $\mathbf{1 1}$, in benzene- $d_{6}$, at room temperature are consistent with the structure shown in Figure 2. As expected for the presence of a hydride ligand in the compounds, the ${ }^{1} \mathrm{H}$ NMR spectra show a high field resonance at $-17.11 \mathrm{ppm}$ for $\mathbf{1 0}$ and at $-17.81 \mathrm{ppm}$ for 11, which appears as a triplet with a H-P coupling constant of about $23 \mathrm{~Hz}$. The ${ }^{13} \mathrm{C}\left\{{ }^{1} \mathrm{H}\right\}$ NMR spectra also reveal a main contribution of the resonance form $\mathbf{b}$. Thus, in agreement with other compounds of this type, ${ }^{9 \mathrm{~d}-\mathrm{f}, 25 \mathrm{~b}, 26,27}$ they contain a low field resonance at $224.7 \mathrm{ppm}$ for $\mathbf{1 0}$ and at $213.8 \mathrm{ppm}$ for $\mathbf{1 1}$, which is observed as a triplet with a C-P coupling constant of about $3 \mathrm{~Hz}$. According to equivalent $\mathrm{P}^{i} \mathrm{Pr}_{2}$ groups, the ${ }^{31} \mathrm{P}\left\{{ }^{1} \mathrm{H}\right\}$ NMR spectra show a singlet at $46.8 \mathrm{ppm}$ for $\mathbf{1 0}$ and at 57.7 ppm for 11.

The ruthenium dihydride $\mathbf{B}$ also reduces the $\mathrm{C}-\mathrm{C}$ double bond of $\alpha, \beta$-unsaturated ketones. The resulting ruthenium( $(0)$ species $\mathbf{D}$ adds a vinylic $\mathrm{C}_{\beta}$ - $\mathrm{H}$ bond of a second molecule of substrate to yield the corresponding hydride-ruthenafuran derivatives. Thus, treatment of toluene solutions of $\mathbf{4}$ with 2.0 equiv of benzylidenacetone and methyl vinyl ketone, in the presence of 1.0 equiv of 2-propanol, under reflux, for $6 \mathrm{~h}$ leads to $\mathrm{RuH}\left\{\kappa^{2}-\mathrm{C}, \mathrm{O}-[\mathrm{C}(\mathrm{R}) \mathrm{CHC}(\mathrm{Me}) \mathrm{O}]\right\}\left\{\operatorname{xant}\left(\mathrm{P}^{i} \mathrm{Pr}_{2}\right)_{2}\right\} \quad(\mathrm{R}=\mathrm{Ph}$ (12), $\mathrm{H}(\mathbf{1 3}))$, the ruthenium counterparts of $\mathbf{1 0}$ and 11, which were isolated as dark green (12) and dark yellow (13) solids in $75 \%$ and $52 \%$ yield, respectively, according to eq 4 .

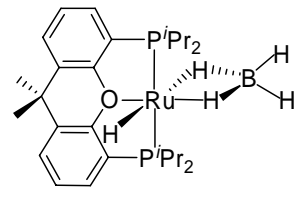

4

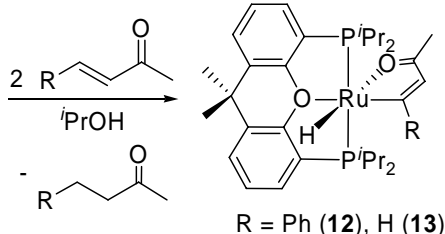

$\mathrm{R}=\mathrm{Ph}(12), \mathrm{H}(13)$
Complex 13 was characterized by X-ray diffraction analysis. Its structure, as that of $\mathbf{1 0}$, has two chemically equivalent but crystallographically independent molecules in the asymmetric unit. Figure 3 shows a drawing of one of them. As expected, the $\mathrm{Ru}\left\{\mathrm{xant}\left(\mathrm{P}^{i} \mathrm{Pr}_{2}\right)_{2}\right\}$ skeleton is mer-coordinated, in this case with angles $\mathrm{P}(1)-\mathrm{Ru}(1)-\mathrm{P}(2), \mathrm{P}(1)-\mathrm{Ru}(1)-\mathrm{O}(2)$, and $\mathrm{P}(2)-\mathrm{Ru}(1)-\mathrm{O}(2)$ of $153.25(9)^{\circ}$ and $153.50(9)^{\circ}, 80.77(15)^{\circ}$ and $81.23(15)^{\circ}$, and $80.45(15)^{\circ}$ and $80.69(16)^{\circ}$, respectively, in a distorted octahedral geometry. The bond lengths in the sequence $\mathrm{Ru}(1)-\mathrm{C}(4)-\mathrm{C}(3)-\mathrm{C}(1)-\mathrm{O}(1)-\mathrm{Ru}(1)$ of $1.946(11)$ and $1.933(10) \AA, 1.386(16)$ and 1.373(15) $\AA, 1.369(15)$ and 1.414(14) $\AA, 1.287(12)$ and 1.257(12) $\AA$, and 2.196(6) and 2.187(6) $\AA$, respectively, agree well with the related parameters of $\mathbf{1 0}$ and support the ruthenafuran formulation.

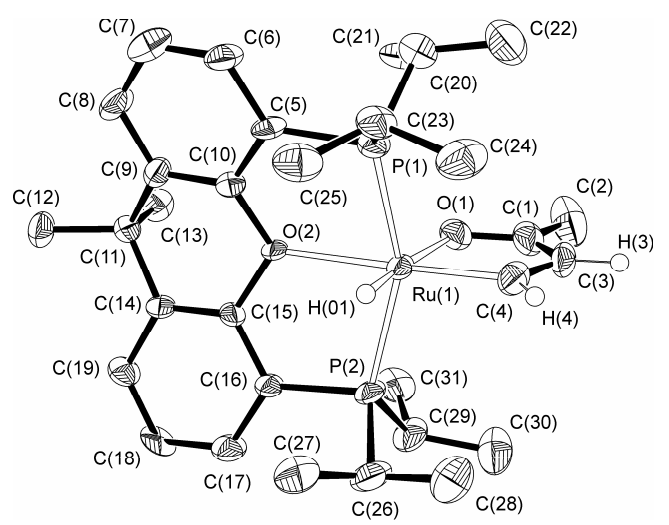

Figure 3. ORTEP diagram of complex 13 (50\% probability ellipsoids). Hydrogen atoms (except hydride, $\mathrm{H}(3)$ and $\mathrm{H}(4)$ ) are omitted for clarity. Selected bond lengths $(\AA)$ and angles $\left({ }^{\circ}\right)$ : $\mathrm{Ru}(1)-\mathrm{P}(1)=2.267(3), 2.265(2), \mathrm{Ru}(1)-\mathrm{P}(2)=2.264(2), 2.274(2)$, $\mathrm{Ru}(1)-\mathrm{O}(1)=2.196(6), 2.187(6), \quad \mathrm{Ru}(1)-\mathrm{O}(2)=2.318(6)$, 2.317(6), $\mathrm{Ru}(1)-\mathrm{C}(4)=1.946(11), 1.933(10), \mathrm{Ru}(1)-\mathrm{H}(01)=$ $1.582(10), 1.581(10), \mathrm{O}(1)-\mathrm{C}(1)=1.287(12), 1.257(12), \mathrm{C}(4)-$ 
$\mathrm{C}(3)=1.386(16), 1.373(15), \mathrm{C}(3)-\mathrm{C}(1)=1.369(15), 1.414(14) \AA ;$ $\mathrm{P}(1)-\mathrm{Ru}(1)-\mathrm{P}(2)=153.25(9), \quad 153.50(9), \quad \mathrm{P}(1)-\mathrm{Ru}(1)-\mathrm{O}(2)=$ 80.77(15), 81.23(15), $\mathrm{P}(2)-\mathrm{Ru}(1)-\mathrm{O}(2)=80.45(15), 80.69(16)$, $\mathrm{O}(1)-\mathrm{Ru}(1)-\mathrm{H}(01)=174(4), 167(3), \mathrm{O}(2)-\mathrm{Ru}(1)-\mathrm{C}(4)=174.2(4)$, 172.1(4), $\mathrm{O}(1)-\mathrm{Ru}(1)-\mathrm{C}(4)=77.7(4), 76.9(4)$.

The ${ }^{1} \mathrm{H},{ }^{13} \mathrm{C}\left\{{ }^{1} \mathrm{H}\right\}$ and ${ }^{31} \mathrm{P}\left\{{ }^{1} \mathrm{H}\right\}$ NMR spectra of $\mathbf{1 2}$ and $\mathbf{1 3}$, in benzene- $d_{6}$, at room temperature are consistent with the structure shown in Figure 3 and with those of their osmium counterparts. In the ${ }^{1} \mathrm{H}$ NMR spectra, the most noticeable feature is the hydride resonance, which appears at -15.35 ppm for $\mathbf{1 2}$ and at $-15.96 \mathrm{ppm}$ for $\mathbf{1 3}$ as a triplet with a H-P coupling constant of about $26 \mathrm{~Hz}$. The ${ }^{13} \mathrm{C}\left\{{ }^{1} \mathrm{H}\right\}$ NMR spectra reveal that the metalafuran character is more marked for ruthenium than for osmium. Thus, the metalated resonance of the activated ketone is observed at $255.0 \mathrm{ppm}$ for $\mathbf{1 2}$ and at $245.6 \mathrm{ppm}$ for $\mathbf{1 3}$, shifted about $30 \mathrm{ppm}$ towards lower field with regard to those of $\mathbf{1 0}$ and 11. These signals are observed as triplets with C-P coupling constants of about $7 \mathrm{~Hz}$. The ${ }^{31} \mathrm{P}\left\{{ }^{1} \mathrm{H}\right\}$ NMR spectra contain a singlet at $63.2 \mathrm{ppm}$ for $\mathbf{1 2}$ and at $71.5 \mathrm{ppm}$ for $\mathbf{1 3}$.

The osmium complex $\mathbf{1}$ and the ruthenium derivative $\mathbf{4}$ activate an ortho-C-H bond of aromatic ketones and a vinylic $\mathrm{C}_{\beta}$ $\mathrm{H}$ bond of $\alpha, \beta$-unsaturated ketones. To study the preference between these processes, we have also investigated their reactions with benzylidenacetophenone (Scheme 4), a substrate containing both functions bonded to the carbonyl unit.

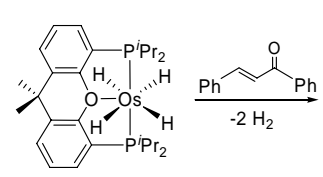

1

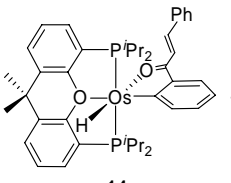

14

$2: 1$

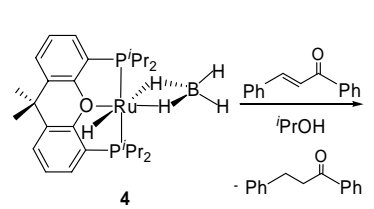

4

$1: 1$

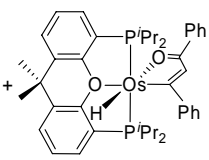

15

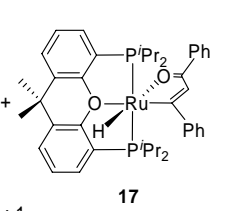

\section{Scheme 4}

Treatment of toluene solutions of 1 with 1.0 equiv of this substrate, under reflux, overnight gives rise to a 2:1 mixture of the osmaisobenzofuran derivative $\mathrm{OsH}\left\{\kappa^{2}-\mathrm{C}, \mathrm{O}-\right.$ $\left.\left[\mathrm{C}_{6} \mathrm{H}_{4} \mathrm{C}(\mathrm{CH}=\mathrm{CHPh}) \mathrm{O}\right]\right\}\left\{\operatorname{xant}\left(\mathrm{P}^{i} \mathrm{Pr}_{2}\right)_{2}\right\}(\mathbf{1 4})$ and the osmafuran compound $\mathrm{OsH}\left\{\kappa^{2}-\mathrm{C}, \mathrm{O}-[\mathrm{C}(\mathrm{Ph}) \mathrm{CHC}(\mathrm{Ph}) \mathrm{O}]\right\}\left\{\operatorname{xant}\left(\mathrm{P}^{i} \mathrm{Pr}_{2}\right)_{2}\right\}$ (15). The ${ }^{1} \mathrm{H},{ }^{13} \mathrm{C}\left\{{ }^{1} \mathrm{H}\right\}$, and ${ }^{31} \mathrm{P}\left\{{ }^{1} \mathrm{H}\right\}$ NMR spectra of the mixture, in benzene- $d_{6}$, at room temperature strongly support the formation of both species. In agreement with $\mathbf{2 , 3 , 7}$, and $\mathbf{8}$, the ${ }^{1} \mathrm{H}$ NMR spectrum of $\mathbf{1 4}$ contains a hydride resonance at $18.09 \mathrm{ppm}$, which is observed as a triplet with a H-P coupling constant of $23.0 \mathrm{~Hz}$. The metalated aryl carbon atom displays at $185.4 \mathrm{ppm}$ a triplet with a C-P coupling constant of $4.3 \mathrm{~Hz}$, in the ${ }^{13} \mathrm{C}\left\{{ }^{1} \mathrm{H}\right\}$ NMR spectrum. The ${ }^{31} \mathrm{P}\left\{{ }^{1} \mathrm{H}\right\}$ NMR spectrum shows at $47.0 \mathrm{ppm}$ a singlet. Characteristic features of $\mathbf{1 5}$ are a triplet $\left(J_{\mathrm{H}-\mathrm{P}}=23.7 \mathrm{~Hz}\right)$ at $-16.37 \mathrm{ppm}$ in the ${ }^{1} \mathrm{H}$ NMR spectrum, a triplet $\left(J_{\mathrm{C}-\mathrm{P}}=2.8 \mathrm{~Hz}\right)$ at $223.3 \mathrm{ppm}$ in the ${ }^{13} \mathrm{C}\left\{{ }^{1} \mathrm{H}\right\}$ NMR spectrum, and a singlet at $47.5 \mathrm{ppm}$ in the ${ }^{31} \mathrm{P}\left\{{ }^{1} \mathrm{H}\right\} \mathrm{NMR}$ spectrum, corresponding to the hydride ligand, the metalated carbon atom of the activated substrate, and the equivalent $\mathrm{P}^{i} \mathrm{Pr}_{2}$ groups, respectively. These spectroscopic data agree well with those of $\mathbf{1 0}$ and $\mathbf{1 1 .}$

The ortho-C-H bond activation is the favored process for the $\mathrm{Os}\left\{\operatorname{xant}\left(\mathrm{P}^{i} \mathrm{Pr}_{2}\right)_{2}\right\}$ skeleton, according to the molar ratio of

the obtained mixture. On the other hand, the $\mathrm{Ru}\left\{\operatorname{xant}\left(\mathrm{P}^{i} \mathrm{Pr}_{2}\right)_{2}\right\}$ moiety does not show any preference. Thus, in contrast to the osmium case, the treatment of toluene solutions of $\mathbf{4}$ with 2.0 equiv of benzylidenacetophenone in the presence of 1.0 equiv of 2-propanol, under reflux overnight, yields a 1:1 mixture of the ruthenaisobenzofuran complex $\mathrm{RuH}\left\{\kappa^{2}-\mathrm{C}, \mathrm{O}-\right.$ $\left.\left[\mathrm{C}_{6} \mathrm{H}_{4} \mathrm{C}(\mathrm{CH}=\mathrm{CHPh}) \mathrm{O}\right]\right\}\left\{\operatorname{xant}\left(\mathrm{P}^{i} \mathrm{Pr}_{2}\right)_{2}\right\} \quad(\mathbf{1 6})$ and the ruthenafuran derivative $\mathrm{RuH}\left\{\kappa^{2}-\mathrm{C}, \mathrm{O}-[\mathrm{C}(\mathrm{Ph}) \mathrm{CHC}(\mathrm{Ph}) \mathrm{O}]\right\}\left\{\operatorname{xant}\left(\mathrm{P}^{i} \mathrm{Pr}_{2}\right)_{2}\right\}$ (17), in addition to 1.0 equiv of saturated ketone. The ${ }^{1} \mathrm{H}$, ${ }^{13} \mathrm{C}\left\{{ }^{1} \mathrm{H}\right\}$ and ${ }^{31} \mathrm{P}\left\{{ }^{1} \mathrm{H}\right\}$ NMR spectra of $\mathbf{1 6}$ in benzene- $d_{6}$, at room temperature, agree well with those of the ruthenaisobenzofuran compounds 5, 6, and $\mathbf{9}$ whereas the spectra of $\mathbf{1 7}$ are in accordance with those of the ruthenafuran derivatives $\mathbf{1 2}$ and 13. Characteristic features of $\mathbf{1 6}$ are: a triplet $\left(J_{\mathrm{H}-\mathrm{P}}=24.0\right.$ $\mathrm{Hz})$ at $-16.30 \mathrm{ppm}$ in the ${ }^{1} \mathrm{H}$ NMR spectrum, a triplet $\left(J_{\mathrm{C}-\mathrm{P}}=\right.$ $9.1 \mathrm{~Hz})$ at $209.9 \mathrm{ppm}$ in the ${ }^{13} \mathrm{C}\left\{{ }^{1} \mathrm{H}\right\}$ NMR spectrum, and a singlet at $62.4 \mathrm{ppm}$ in the ${ }^{31} \mathrm{P}\left\{{ }^{1} \mathrm{H}\right\}$ NMR spectrum, whereas the related parameters of $\mathbf{1 7}$ are: a triplet $\left(J_{\mathrm{H}-\mathrm{P}}=26.1 \mathrm{~Hz}\right)$ at $14.46 \mathrm{ppm}$ in the ${ }^{1} \mathrm{H}$ NMR spectrum, a triplet $\left(J_{\mathrm{C}-\mathrm{P}}=6.7 \mathrm{~Hz}\right)$ at $255.0 \mathrm{ppm}$ in the ${ }^{13} \mathrm{C}\left\{{ }^{1} \mathrm{H}\right\}$ NMR spectrum, and a singlet at 64.1 ppm in the ${ }^{31} \mathrm{P}\left\{{ }^{1} \mathrm{H}\right\}$ NMR spectrum.

4. Aldehydes. Aldehydes are ketone counterparts with the carbonyl group bonded to a hydrogen atom. The activation of this bond is of great relevance in connection with the catalytic decarbonylation of these substrates ${ }^{28}$ and by its importance in organometallic $^{29}$ and organic synthesis. ${ }^{30}$ The OC-H bond is about $23 \mathrm{kcal} \cdot \mathrm{mol}^{-1}$ weaker than the $\mathrm{C}-\mathrm{H}$ bond of a phenyl group. As a consequence, the OC-H cleavage and the ortho-C$\mathrm{H}$ bond activation in aromatic aldehydes are competitive processes. Thus, depending upon the metal precursor, products of both types of reactions have been isolated and characterized. ${ }^{31}$ Being nterested in knowing the capacity of the Os $\left\{\operatorname{xant}\left(\mathrm{P}^{i} \operatorname{Pr}_{2}\right)_{2}\right\}$ and $\operatorname{Ru}\left\{\operatorname{xant}\left(\mathrm{P}^{i} \operatorname{Pr}_{2}\right)_{2}\right\}$ skeletons for discerning between both types of bonds, we have also studied the reactions of precursors 1 and $\mathbf{4}$ with benzaldehyde.

Treatment of toluene solutions of $\mathbf{1}$ with 1.2 equiv of benzaldehyde, under reflux, for $15 \mathrm{~h}$ leads to the aryl-hydridecarbonyl derivative $\mathrm{OsH}(\mathrm{Ph})(\mathrm{CO})\left\{\operatorname{xant}\left(\mathrm{P}^{i} \mathrm{Pr}_{2}\right)_{2}\right\} \quad$ (18), which was isolated as a white solid in $71 \%$ yield. Its formation involves the activation of the OC-H bond to afford an unsaturated hydride-acyl intermediate $\mathbf{E}$, which evolves by deinsertion of the phenyl group (Scheme 5). The presence of the hydride ligand in $\mathbf{1 8}$ is revealed by a triplet $\left(J_{\mathrm{H}-\mathrm{P}}=21.3 \mathrm{~Hz}\right)$ at $-6.96 \mathrm{ppm}$ in the ${ }^{1} \mathrm{H}$ NMR spectrum, which agrees well with those of $\mathrm{OsH}(\mathrm{Ph})(\mathrm{CO})_{2}\left(\mathrm{P}^{i} \mathrm{Pr}_{3}\right)_{2} \quad(\delta \quad-6.59)^{31}$ and $\mathrm{OsH}(\mathrm{Ph})(\mathrm{CO})\left\{\mathrm{dbf}\left(\mathrm{P}^{i} \mathrm{Pr}_{2}\right)_{2}\right\}(\delta-8.07),{ }^{12 \mathrm{~b}}$ where the hydride and carbonyl ligands are also disposed trans. In the ${ }^{13} \mathrm{C}\left\{{ }^{1} \mathrm{H}\right\}$ NMR spectrum, the carbonyl and metalated aryl resonances appear at $186.9\left(\mathrm{t}, J_{\mathrm{C}-\mathrm{P}}=7.6 \mathrm{~Hz}\right)$ and $156.2 \mathrm{ppm}\left(\mathrm{t}, J_{\mathrm{C}-\mathrm{P}}=8.0 \mathrm{~Hz}\right)$, respectively. In agreement with the ${ }^{13} \mathrm{C}\left\{{ }^{1} \mathrm{H}\right\}$ NMR spectrum, the IR shows a $v(\mathrm{CO})$ band at $1871 \mathrm{~cm}^{-1}$. The ${ }^{31} \mathrm{P}\left\{{ }^{1} \mathrm{H}\right\}$ NMR spectrum contains at $53.0 \mathrm{ppm}$ a singlet.

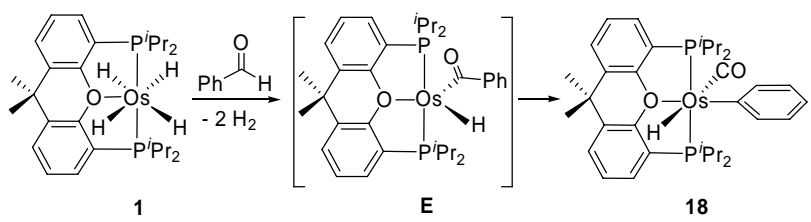

Scheme 5 
The ruthenium skeleton $\mathrm{Ru}\left\{\operatorname{xant}\left(\mathrm{P}^{i} \mathrm{Pr}_{2}\right)_{2}\right\}$ also favors the $\mathrm{OC}-\mathrm{H}$ bond activation over the cleavage of an ortho-C-H bond of the phenyl substituent. Treatment of toluene solutions of $\mathbf{4}$ with 2.0 equiv of benzaldehyde, in the presence of 1.0 equiv of 2-propanol, at $80^{\circ} \mathrm{C}$, for $14 \mathrm{~h}$ gives rise to the ruthenium counterpart $\mathrm{RuH}(\mathrm{Ph})(\mathrm{CO})\left\{\operatorname{xant}\left(\mathrm{P}^{i} \mathrm{Pr}_{2}\right)_{2}\right\}$ (19), via the unsaturated hydride-acyl intermediate F (Scheme 6). Complex 19 was isolated as a pale brown solid in $69 \%$ yield. Characteristic spectroscopic features of $\mathbf{1 9}$ are a triplet $\left(J_{\mathrm{H}-\mathrm{P}}=19.2 \mathrm{~Hz}\right)$ at $13.71 \mathrm{ppm}$, in the ${ }^{1} \mathrm{H}$ NMR spectrum, due to the hydride ligand; triplets at $208.5\left(J_{\mathrm{C}-\mathrm{P}}=6.5 \mathrm{~Hz}\right)$ and $156.0 \mathrm{ppm}\left(J_{\mathrm{C}-\mathrm{P}}=\right.$ $8.1 \mathrm{~Hz})$, in the ${ }^{13} \mathrm{C}\left\{{ }^{1} \mathrm{H}\right\}$ NMR spectrum, assigned to the carbonyl group and the metalated carbon atom, respectively; a singlet at $69.5 \mathrm{ppm}$, in the ${ }^{31} \mathrm{P}\left\{{ }^{1} \mathrm{H}\right\}$ NMR spectrum, corresponding to the equivalent $\mathrm{P}^{i} \mathrm{Pr}_{2}$ groups of the diphosphine; and a $v(\mathrm{CO})$ band at $1926 \mathrm{~cm}^{-1}$ in the IR.

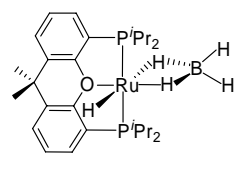

4
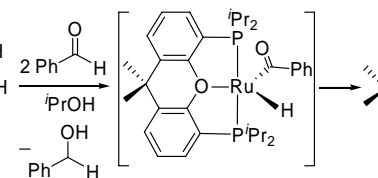

$\mathrm{F}$

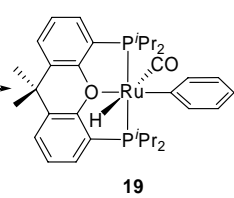

19
Scheme 6

The OC-H bond activation is also preferred over the vinylic $\mathrm{C}$ - $\mathrm{H}$ bond activation in $\alpha, \beta$-unsaturated aldehydes. Thus, similarly to benzaldehyde, treatment of toluene solutions of 1 with 1.2 equiv of 1-cyclohexene-1-carboxaldehyde, under reflux, for $14 \mathrm{~h}$ leads to $\mathrm{OsH}\left(\mathrm{C}_{6} \mathrm{H}_{9}\right)(\mathrm{CO})\left\{\operatorname{xant}\left(\mathrm{P}^{i} \mathrm{Pr}_{2}\right)_{2}\right\} \quad$ (20), the cyclohexenyl counterpart of $\mathbf{1 8}$, although in this case, the OC$\mathrm{H}$ activation-deinsertion product is contaminated with the dihydride-carbonyl derivative $\mathrm{OsH}_{2}(\mathrm{CO})\left\{\operatorname{xant}\left(\mathrm{P}^{i} \mathrm{Pr}_{2}\right)_{2}\right\} \quad$ (21), which is generated as a consequence of the release of 1,3cyclohexadiene from 20 (Scheme 7). In agreement with 18, the ${ }^{1} \mathrm{H}$ NMR spectrum of $\mathbf{2 0}$, in benzene- $d_{6}$, at room temperature shows the hydride resonance at $-7.23 \mathrm{ppm}$ as a triplet with a H-P coupling constant of $21.2 \mathrm{~Hz}$, whereas the carbonyl and metalated alkenyl resonances are observed at 187.3 and 157.4 ppm, respectively, in the ${ }^{13} \mathrm{C}\left\{{ }^{1} \mathrm{H}\right\}$ NMR spectrum. A singlet at $52.1 \mathrm{ppm}$, in the ${ }^{31} \mathrm{P}\left\{{ }^{1} \mathrm{H}\right\}$ NMR spectrum, and a $v(\mathrm{CO})$ band at $1872 \mathrm{~cm}^{-1}$ in the IR are also characteristic features of this compound.
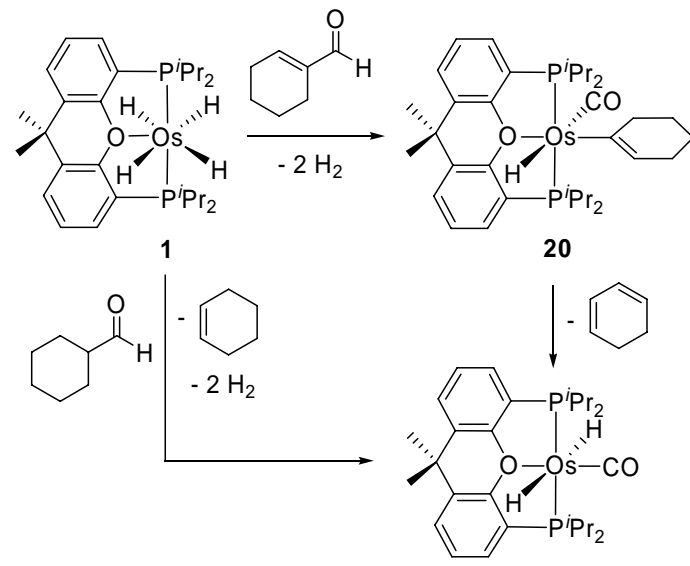

21

Scheme 7

The dehydrogenation of the substituent of the aldehyde is favored for alkyl with regard to alkenyl. Thus, the dihydride complex 21 was obtained as a pure organometallic species, along with cyclohexene, from the reaction of $\mathbf{1}$ with cyclohexane carboxaldehyde, in toluene, under reflux. This dihydride derivative was isolated as yellow crystals in $72 \%$ yield and characterized by X-ray diffraction analysis. Its structure (Figure 4) proves the dehydrogenative decarbonylation of the substrate. In agreement with $\mathbf{2}, \mathbf{1 0}$, and $\mathbf{1 3}$ the $\mathrm{Os}\left\{\operatorname{xant}\left(\mathrm{P}^{i} \mathrm{Pr}_{2}\right)_{2}\right\}$ skeleton is mer-coordinated with $\mathrm{P}(1)-\mathrm{Os}-\mathrm{P}(2), \mathrm{P}(1)-\mathrm{Os}-\mathrm{O}(1)$, and $\mathrm{P}(2)-\mathrm{Os}-\mathrm{O}(1)$ angles of $162.14(5)^{\circ}, 81.56(8)^{\circ}$, and $81.03(9)^{\circ}$, respectively. Thus, the coordination geometry around the osmium atom can be rationalized as a distorted octahedron with trans hydrides $\left(\mathrm{H}(01)-\mathrm{Os}-\mathrm{H}(02)=178(2)^{\circ}\right)$ and the carbonyl group trans to the oxygen atom of the diphosphine $\left(\mathrm{O}(1)\right.$-Os- $\left.\mathrm{C}(28)=178.0(2)^{\circ}\right)$. According to the trans-dihydride and carbonyl nature of the compound, its IR contains $v(\mathrm{Os}-\mathrm{H})$ and $v(\mathrm{CO})$ bands at 1688 and $1878 \mathrm{~cm}^{-1}$, respectively. As expected for equivalent hydrides, the ${ }^{1} \mathrm{H}$ NMR spectrum, in benzene- $d_{6}$, at room temperature contains only one hydride resonance, which is observed at $-4.08 \mathrm{ppm}$ as a triplet with a H-P coupling constant of $17.7 \mathrm{~Hz}$. In the ${ }^{13} \mathrm{C}\left\{{ }^{1} \mathrm{H}\right\}$ NMR spectrum, the most noticeable feature is the signal due to the carbonyl ligand, which appears at $186.0 \mathrm{ppm}$ as a triplet with a C-P coupling constant of $7.8 \mathrm{~Hz}$. The ${ }^{31} \mathrm{P}\left\{{ }^{1} \mathrm{H}\right\}$ NMR spectrum shows a singlet at $70.8 \mathrm{ppm}$.

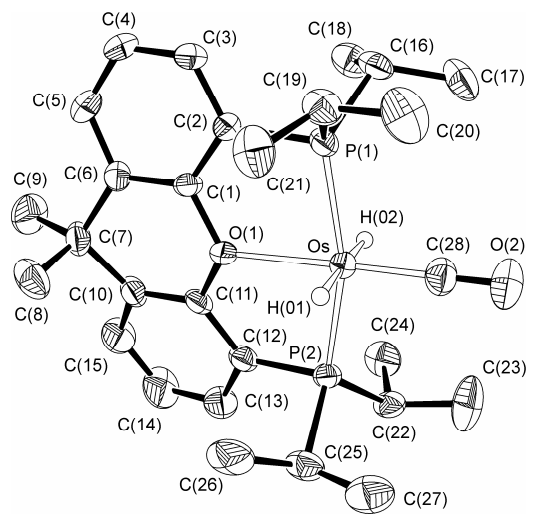

Figure 4. ORTEP diagram of complex 21 (50\% probability ellipsoids). Hydrogen atoms (except hydrides) are omitted for clarity. Selected bond lengths $(\AA)$ and angles $\left({ }^{\circ}\right)$ : Os-P $(1)=2.2854(13)$, Os- $\mathrm{P}(2)=2.2918(13)$, Os-O $(1)=2.253(3)$, Os-C $(28)=1.798(6)$, Os-H(01) $=1.586(10)$, Os-H(02) = 1.592(10); P(1)-Os-P(2) = 162.14(5), $\mathrm{P}(1)-\mathrm{Os}-\mathrm{O}(1)=81.56(8), \mathrm{P}(2)-\mathrm{Os}-\mathrm{O}(1)=81.03(9)$, $\mathrm{O}(1)-\mathrm{Os}-\mathrm{C}(28)=178.0(2), \mathrm{H}(01)-\mathrm{Os}-\mathrm{H}(02)=178(2)$.

\section{CONCLUDING REMARKS}

This study has revealed that the tetrahydride osmium complex $\mathrm{OsH}_{4}\left\{\operatorname{xant}\left(\mathrm{P}^{i} \mathrm{Pr}_{2}\right)_{2}\right\}$ and its ruthenium counterpart $\mathrm{RuH}\left(\eta^{2}-\mathrm{H}_{2} \mathrm{BH}_{2}\right)\left\{\operatorname{xant}\left(\mathrm{P}^{i} \mathrm{Pr}_{2}\right)_{2}\right\}$ promote the ortho-C-H bond activation of aromatic and fluorinated aromatic ketones, the $\mathrm{C}_{\beta}-\mathrm{H}$ bond activation of $\alpha, \beta$-unsaturated ketones, and the OC$\mathrm{H}$ bond activation of aldehydes to afford metalaisobenzofuran, metalafuran, hydride-phenyl-carbonyl, hydride-alkenylcarbonyl and dihydride-carbonyl derivatives depending upon the nature of the substrates. Because the ruthenium precursor reduces $\mathrm{C}-\mathrm{O}$ and $\mathrm{C}-\mathrm{C}$ double bonds, 1.0 equiv of sacrificial substrate is necessary for the activation in this case.

Isotope labeling results suggest that the origin of the selectivity of the ortho-C-H bond activation of aromatic ketones is only thermodynamic, since the activations of the $\mathrm{C}-\mathrm{H}$ bonds in 
meta and para positions are kinetically preferred. In aromatic $\alpha, \beta$-unsaturated ketones, the ortho- $\mathrm{C}-\mathrm{H}$ bond activation is slightly favored over the $\mathrm{C}_{\beta}-\mathrm{H}$ bond activation, from a thermodynamic point of view, for osmium whereas ruthenium does not show any preference. In contrast, both osmium and ruthenium favor the $\mathrm{OC}-\mathrm{H}$ bond activation over the cleavage of an ortho-C-H bond in aromatic aldehydes. In this case, the $\mathrm{C}-\mathrm{H}$ bond activation is the initial step for the decarbonylation of the substrate. Alkyl aldehydes undergo dehydrogenation of the substituent in addition to the decarbonylation process.

In conclusion, the $\mathrm{M}\left\{\mathrm{xant}\left(\mathrm{P}^{i} \mathrm{Pr}_{2}\right)_{2}\right\}(\mathrm{M}=\mathrm{Os}, \mathrm{Ru})$ fragments allow to generate species able of activating $\mathrm{C}-\mathrm{H}$ bonds of carbonyl derivatives and to stabilize metalaisobenzofuran and metalafuran derivatives, among other interesting organometallic compounds.

\section{EXPERIMENTAL SECTION}

All reactions were carried out with rigorous exclusion of air using Schlenk-tube techniques. Methanol was dried and distilled under argon. Other solvents were obtained oxygen- and water-free from an MBraun solvent purification apparatus. NMR spectra were recorded on a Varian Gemini 2000, a Bruker ARX $300 \mathrm{MHz}$, a Bruker Avance $300 \mathrm{MHz}$, or a Bruker Avance $400 \mathrm{MHz}$ instrument. Chemical shifts (expressed in parts per million) are referenced to residual solvent peaks $\left({ }^{1} \mathrm{H},{ }^{1} \mathrm{H}\left\{{ }^{31} \mathrm{P}\right\},{ }^{13} \mathrm{C}\left\{{ }^{1} \mathrm{H}\right\}\right)$ or external standard $\left({ }^{31} \mathrm{P}\left\{{ }^{1} \mathrm{H}\right\}\right.$ to $85 \%$ $\mathrm{H}_{3} \mathrm{PO}_{4}$ and ${ }^{19} \mathrm{~F}$ to $\left.\mathrm{CFCl}_{3}\right)$. Coupling constants $J$ and $N(N=J(\mathrm{PH})+$ $J\left(\mathrm{P}^{\prime} \mathrm{H}\right)$ for ${ }^{1} \mathrm{H}$ and $N=J(\mathrm{PC})+J\left(\mathrm{P}^{\prime} \mathrm{C}\right)$ for $\left.{ }^{13} \mathrm{C}\left\{{ }^{1} \mathrm{H}\right\}\right)$ are given in hertz. ${ }^{13} \mathrm{C}\left\{{ }^{1} \mathrm{H}\right\}$ NMR assignments were made with HSQC and HMBC spectra. Attenuated total reflection infrared spectra (ATR-IR) of solid samples were run on a Perkin-Elmer Spectrum 100 FT-IR spectrometer. Elemental analyses were carried out in a Perkin-Elmer 2400 $\mathrm{CHNS/O}$ analyzer. High-resolution electrospray mass spectra (HRMS) were acquired using a MicroTOF-Q hybrid quadrupole timeof-flight spectrometer (Bruker Daltonics, Bremen, Germany). All reagents were purchased from commercial sources and used as received. $\mathrm{OsH}_{4}\left\{\operatorname{xant}\left(\mathrm{P}^{i} \mathrm{Pr}_{2}\right)_{2}\right\} \quad(\mathbf{1}),{ }^{12 \mathrm{~d}} \operatorname{RuH}\left(\eta^{2}-\mathrm{H}_{2} \mathrm{BH}_{2}\right)\left\{\operatorname{xant}\left(\mathrm{P}^{i} \mathrm{Pr}_{2}\right)_{2}\right\}$ (4) $)^{12 \mathrm{f}}$ and 9,9-dimethyl-4,5-bis(diisopropylphosphino)xanthene $\left(\operatorname{xant}\left(\mathrm{P}^{i} \operatorname{Pr}_{2}\right)_{2}\right)^{12 \mathrm{a}}$ were prepared according to the published methods.

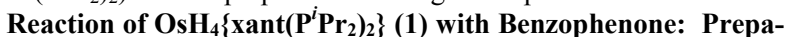
ration of OsH $\left\{\kappa^{2}-\mathrm{C}, \mathrm{O}-\left[\mathrm{C}_{6} \mathrm{H}_{4} \mathrm{C}(\mathrm{Ph}) \mathrm{O}\right]\right\}\left\{\operatorname{xant}\left(\mathrm{P}^{i} \mathbf{P r}_{2}\right)_{2}\right\}$ (2). A solution of $1(63 \mathrm{mg}, 0.099 \mathrm{mmol})$ in toluene $(6 \mathrm{~mL})$ was treated with the stoichiometric amount of benzophenone $(18 \mathrm{mg}, 0.099 \mathrm{mmol})$ and the resulting mixture was heated to reflux overnight. During this time the color of the mixture changed from colorless to deep purple. After being cooled at room temperature, the solution was evaporated to afford a purple residue. Addition of methanol $(2 \mathrm{~mL})$ at $-78^{\circ} \mathrm{C}$ (dry ice/ ${ }^{\mathrm{P}} \mathrm{PrOH}$ bath) afforded a purple solid that was washed with methanol $(2 \times 2 \mathrm{~mL})$ and dried in vacuo. Yield: $60 \mathrm{mg}(73 \%)$. Anal. Calcd. for $\mathrm{C}_{40} \mathrm{H}_{50} \mathrm{O}_{2} \mathrm{OsP}_{2}$ : C, 58.95; H, 6.18. Found: C, 59.32; H, 6.02. HRMS (electrospray, $m / z$ ): calcd. for $\mathrm{C}_{40} \mathrm{H}_{49} \mathrm{O}_{2} \mathrm{OsP}_{2}[\mathrm{M}-\mathrm{H}]^{+}$: 815.2820, found: 815.2838. IR $\left(\mathrm{cm}^{-1}\right)$ : v(Os-H) 2047 (s). ${ }^{1} \mathrm{H}$ NMR $\left(300 \mathrm{MHz}, \mathrm{C}_{6} \mathrm{D}_{6}, 298 \mathrm{~K}\right): \delta 8.56\left(\mathrm{~d}, J_{\mathrm{H}-\mathrm{H}}=8.0,1 \mathrm{H}, \mathrm{CH}_{\text {arom }}\right), 8.11(\mathrm{~d}$, $\left.J_{\mathrm{H}-\mathrm{H}}=8.1,1 \mathrm{H}, \mathrm{CH}_{\text {arom }}\right), 7.98\left(\mathrm{~d}, J_{\mathrm{H}-\mathrm{H}}=7.0,2 \mathrm{H}, \mathrm{CH}_{\text {arom }}\right), 7.21-7.09(\mathrm{~m}$, $5 \mathrm{H}, \mathrm{CH}_{\text {arom- }}$-xant $\left(\mathrm{P}^{i} \mathrm{Pr}_{2}\right)_{2}$ and $\left.\mathrm{CH}_{\text {arom }}\right), 6.97\left(\mathrm{dd}, J_{\mathrm{H}-\mathrm{H}}=7.5, J_{\mathrm{H}-\mathrm{H}}=1.2\right.$, $\left.2 \mathrm{H}, \mathrm{CH}_{\text {arom }}-\operatorname{xant}\left(\mathrm{P}^{i} \mathrm{Pr}_{2}\right)_{2}\right), 6.87\left(\mathrm{t}, J_{\mathrm{H}-\mathrm{H}}=7.5,2 \mathrm{H}, \mathrm{CH}_{\text {arom }}-\mathrm{Xant}\left(\mathrm{P}^{i} \operatorname{Pr}_{2}\right)_{2}\right)$, $6.76\left(\mathrm{t}, J_{\mathrm{H}-\mathrm{H}}=6.9,1 \mathrm{H}, \mathrm{CH}_{\text {arom }}\right), 6.66\left(\mathrm{t}, J_{\mathrm{H}-\mathrm{H}}=8.1,1 \mathrm{H}, \mathrm{CH}_{\text {arom }}\right), 2.41$ $\left(\mathrm{m}, 2 \mathrm{H}, \mathrm{PCH}\left(\mathrm{CH}_{3}\right)_{2}\right), 2.23\left(\mathrm{~m}, 2 \mathrm{H}, \mathrm{PCH}\left(\mathrm{CH}_{3}\right)_{2}\right), 1.36\left(\mathrm{~s}, 3 \mathrm{H}, \mathrm{CH}_{3}\right)$, $1.34\left(\mathrm{dvt}, J_{\mathrm{H}-\mathrm{H}}=6.7, N=16.6,6 \mathrm{H}, \mathrm{PCH}\left(\mathrm{CH}_{3}\right)_{2}\right), 1.18\left(\mathrm{dvt}, J_{\mathrm{H}-\mathrm{H}}=7.0\right.$, $\left.N=14.5,6 \mathrm{H}, \mathrm{PCH}\left(\mathrm{CH}_{3}\right)_{2}\right), 1.11\left(\mathrm{~s}, 3 \mathrm{H}, \mathrm{CH}_{3}\right), 0.89\left(\mathrm{dvt}, J_{\mathrm{H}-\mathrm{H}}=6.9, N\right.$ $\left.=14.1,6 \mathrm{H}, \mathrm{PCH}\left(\mathrm{CH}_{3}\right)_{2}\right), 0.72\left(\mathrm{dvt}, J_{\mathrm{H}-\mathrm{H}}=6.9, N=15.6,6 \mathrm{H}\right.$, $\left.\mathrm{PCH}\left(\mathrm{CH}_{3}\right)_{2}\right),-17.03\left(\mathrm{t}, J_{\mathrm{H}-\mathrm{P}}=23.6,1 \mathrm{H}, \mathrm{OsH}\right) .{ }^{13} \mathrm{C}\left\{{ }^{1} \mathrm{H}\right\} \mathrm{NMR}(75.47$ $\left.\mathrm{MHz}, \mathrm{C}_{6} \mathrm{D}_{6}, 298 \mathrm{~K}\right): \delta 205.3\left(\mathrm{t}, J_{\mathrm{C}-\mathrm{P}}=2.2, \mathrm{CO}\right), 187.4\left(\mathrm{t}, J_{\mathrm{C}-\mathrm{P}}=4.3\right.$, OsC), 159.3 (vt, $\left.N=12.8, \mathrm{C}_{\text {arom }}-\operatorname{xant}\left(\mathrm{P}^{i} \operatorname{Pr}_{2}\right)_{2}\right), 149.8\left(\mathrm{~s}, \mathrm{CH}_{\text {arom }}\right)$, 140.6, 140.2 (both s, $\mathrm{C}_{\text {arom}}$ ), 133.8 (s, $\mathrm{CH}_{\text {arom }}$ ), 132.6 (vt, $N=5.3$, $\left.\mathrm{C}_{\text {arom-Xant }}\left(\mathrm{P}^{i} \mathrm{Pr}_{2}\right)_{2}\right), 129.8,129.5,129.3\left(\right.$ all s, $\left.\mathrm{CH}_{\text {arom }}\right), 129.1\left(\mathrm{~s}, \mathrm{CH}_{\mathrm{a}-}\right.$ rom-Xant $\left.\left(\mathrm{P}^{i} \mathrm{Pr}_{2}\right)_{2}\right), 128.8\left(\mathrm{vt}, N=28.7, \mathrm{C}_{\text {ipso }}-\operatorname{Xant}\left(\mathrm{P}^{i} \mathrm{Pr}_{2}\right)_{2}\right), 128.1(\mathrm{~s}$, $\left.\mathrm{CH}_{\text {arom }}\right), 125.8$ (s, $\left.\mathrm{CH}_{\text {arom }}-\operatorname{Xant}\left(\mathrm{P}^{i} \operatorname{Pr}_{2}\right)_{2}\right), 124.8\left(\mathrm{vt}, N=4.4, \mathrm{CH}_{\text {arom }}{ }^{-}\right.$ xant $\left.\left(\mathrm{P}^{i} \mathrm{Pr}_{2}\right)_{2}\right), 115.2\left(\mathrm{~s}, \mathrm{CH}_{\text {arom }}\right), 34.8\left(\mathrm{~s}, \mathrm{C}\left(\mathrm{CH}_{3}\right)_{2}\right), 34.6\left(\mathrm{~s}, \mathrm{C}\left(\mathrm{CH}_{3}\right)_{2}\right)$,
30.1 (vt, $\left.N=18.1, \mathrm{PCH}\left(\mathrm{CH}_{3}\right)_{2}\right), 29.4$ (vt, $\left.N=33.9, \mathrm{PCH}\left(\mathrm{CH}_{3}\right)_{2}\right), 25.9$ (s, $\left.\mathrm{C}\left(\mathrm{CH}_{3}\right)_{2}\right), 20.1$ (vt, $\left.N=6.8, \operatorname{PCH}\left(\mathrm{CH}_{3}\right)_{2}\right), 20.1\left(\mathrm{~s}, \operatorname{PCH}\left(\mathrm{CH}_{3}\right)_{2}\right)$, 18.7 (vt, $\left.N=7.5, \operatorname{PCH}\left(C_{3}\right)_{2}\right), 18.7\left(\mathrm{~s}, \mathrm{PCH}\left(\mathrm{CH}_{3}\right)_{2}\right) .{ }^{31} \mathrm{P}\left\{{ }^{1} \mathrm{H}\right\} \mathrm{NMR}$ $\left(121.43 \mathrm{MHz}, \mathrm{C}_{6} \mathrm{D}_{6}, 298 \mathrm{~K}\right): \delta 47.0$ (s).

Reaction of $\mathrm{OsH}_{4}\left\{\operatorname{xant}\left(\mathbf{P}^{i} \mathbf{P r}_{2}\right)_{2}\right\}$ (1) with Perdeuterated Benzophenone. This reaction was carried out analogously as described for 2, starting from 1 ( $75 \mathrm{mg}, 0.118 \mathrm{mmol}$ ) and perdeuterated benzophenone $(22.6 \mathrm{mg}, 0.118 \mathrm{mmol})$. Purple solid. Yield: $65 \mathrm{mg} .{ }^{1} \mathrm{H}$ NMR $\left(300 \mathrm{MHz}, \mathrm{C}_{6} \mathrm{D}_{6}, 298 \mathrm{~K}\right.$, aromatic region, integrals with respect to one of the $\mathrm{PCH}\left(\mathrm{CH}_{3}\right)_{2}$ signals $\left.(2 \mathrm{H})\right): \delta 8.57\left(\mathrm{~d}, J_{\mathrm{H}-\mathrm{H}}=8.0,0.8 \mathrm{H}\right.$, $\left.\mathrm{CH}_{\text {arom }}\right), 8.12\left(\mathrm{~d}, J_{\mathrm{H}-\mathrm{H}}=8.1,0.6 \mathrm{H}, \mathrm{CH}_{\text {arom }}\right), 8.00\left(\mathrm{~d}, J_{\mathrm{H}-\mathrm{H}}=7.0,1.2 \mathrm{H}\right.$, $\left.\mathrm{CH}_{\text {arom}}\right)$.

Reaction of $\mathrm{OsH}_{4}\left\{\operatorname{xant}\left(\mathrm{P}^{i} \mathrm{Pr}_{2}\right)_{2}\right\}$ (1) with Acetophenone: Preparation of $\mathrm{OsH}\left\{\boldsymbol{\kappa}^{2}-\mathrm{C}, \mathrm{O}-\left[\mathrm{C}_{6} \mathrm{H}_{4} \mathbf{C}\left(\mathrm{CH}_{3}\right) \mathrm{O}\right]\right\}\left\{\operatorname{xant}\left(\mathrm{P}^{i} \mathbf{P r}_{2}\right)_{2}\right\} \quad(3)$. This complex was prepared analogously as described for $\mathbf{2}$ starting from $\mathbf{1}$ (75 mg, $0.118 \mathrm{mmol}$ ) and acetophenone $(15 \mu \mathrm{L}, 0.118 \mathrm{mmol})$. Dark red solid. Yield: $61 \mathrm{mg}(69 \%)$. Anal. Calcd. for $\mathrm{C}_{35} \mathrm{H}_{48} \mathrm{O}_{2} \mathrm{OsP}_{2}$ : C, 55.83; H, 6.43. Found: C, 55.44; H, 6.12. HRMS (electrospray, $\mathrm{m} / \mathrm{z}$ ): calcd. for $\mathrm{C}_{35} \mathrm{H}_{47} \mathrm{O}_{2} \mathrm{OsP}_{2}[\mathrm{M}-\mathrm{H}]^{+}$: 753.2662, found: 753.2959. IR $\left(\mathrm{cm}^{-1}\right): v(\mathrm{Os}-\mathrm{H}) 2047(\mathrm{~s}) .{ }^{1} \mathrm{H}$ NMR $\left(300 \mathrm{MHz}, \mathrm{C}_{6} \mathrm{D}_{6}, 298 \mathrm{~K}\right): \delta 8.58$ $\left(\mathrm{d}, J_{\mathrm{H}-\mathrm{H}}=7.8,1 \mathrm{H}, \mathrm{CH}_{\text {arom }}\right), 7.81\left(\mathrm{~d}, J_{\mathrm{H}-\mathrm{H}}=7.8,1 \mathrm{H}, \mathrm{CH}_{\text {arom }}\right), 7.32(\mathrm{~m}$, $2 \mathrm{H}, \mathrm{CH}_{\text {arom- }}$-Xant $\left.\left(\mathrm{P}^{i} \mathrm{Pr}_{2}\right)_{2}\right), 6.97\left(\mathrm{dd}, J_{\mathrm{H}-\mathrm{H}}=7.8, J_{\mathrm{H}-\mathrm{H}}=1.5,2 \mathrm{H}, \mathrm{CH}_{\text {arom- }}{ }^{-}\right.$ $\left.\operatorname{xant}\left(\mathrm{P}^{i} \mathrm{Pr}_{2}\right)_{2}\right), 6.87\left(\mathrm{t}, J_{\mathrm{H}-\mathrm{H}}=7.5,2 \mathrm{H}, \mathrm{CH}_{\text {arom }}-\mathrm{xant}\left(\mathrm{P}^{i} \mathrm{Pr}_{2}\right)_{2}\right), 6.91\left(\mathrm{t}, J_{\mathrm{H}-\mathrm{H}}\right.$ $\left.=7.8,1 \mathrm{H}, \mathrm{CH}_{\text {arom }}\right), 6.80\left(\mathrm{t}, J_{\mathrm{H}-\mathrm{H}}=7.8,1 \mathrm{H}, \mathrm{CH}_{\text {arom }}\right), 2.78(\mathrm{~s}, 3 \mathrm{H}$, $\left.\mathrm{COCH}_{3}\right), 2.52\left(\mathrm{~m}, 2 \mathrm{H}, \mathrm{PCH}\left(\mathrm{CH}_{3}\right)_{2}\right), 2.35\left(\mathrm{~m}, 2 \mathrm{H}, \mathrm{PCH}\left(\mathrm{CH}_{3}\right)_{2}\right), 1.48$ $\left(\mathrm{s}, 3 \mathrm{H}, \mathrm{CH}_{3}\right), 1.45$ (dvt, $\left.J_{\mathrm{H}-\mathrm{H}}=9.6, N=16.5,6 \mathrm{H}, \mathrm{PCH}\left(\mathrm{CH}_{3}\right)_{2}\right), 1.29$ $\left(\mathrm{dvt}, J_{\mathrm{H}-\mathrm{H}}=7.5, N=14.4,6 \mathrm{H}, \mathrm{PCH}\left(\mathrm{CH}_{3}\right)_{2}\right), 1.23\left(\mathrm{~s}, 3 \mathrm{H}, \mathrm{CH}_{3}\right), 1.05$ $\left(\mathrm{dvt}, J_{\mathrm{H}-\mathrm{H}}=6.6, N=13.5,6 \mathrm{H}, \mathrm{PCH}\left(\mathrm{CH}_{3}\right)_{2}\right), 0.85\left(\mathrm{dvt}, J_{\mathrm{H}-\mathrm{H}}=8.4, N=\right.$ $\left.15.3,6 \mathrm{H}, \mathrm{PCH}\left(\mathrm{CH}_{3}\right)_{2}\right),-18.01\left(\mathrm{t}, J_{\mathrm{H}-\mathrm{P}}=23.1,1 \mathrm{H}, \mathrm{OsH}\right) .{ }^{13} \mathrm{C}\left\{{ }^{1} \mathrm{H}\right\}$ NMR $\left(75.47 \mathrm{MHz}, \mathrm{C}_{6} \mathrm{D}_{6}, 298 \mathrm{~K}\right): \delta 206.9\left(\mathrm{t}, J_{\mathrm{C}-\mathrm{P}}=1.8, \mathrm{CO}\right), 184.3(\mathrm{t}$, $\left.J_{\mathrm{C}-\mathrm{P}}=4.4, \mathrm{OsC}\right), 159.1\left(\mathrm{vt}, N=13.5, \mathrm{C}_{\text {arom }}-\operatorname{Xant}\left(\mathrm{P}^{i} \mathrm{Pr}_{2}\right)_{2}\right), 149.3(\mathrm{~s}$, $\mathrm{CH}_{\text {arom }}$ ), 141.9 (s, $\left.\mathrm{C}_{\text {arom }}\right), 132.2$ (vt, $\left.N=5.5, \mathrm{C}_{\text {arom }}-\mathrm{xant}\left(\mathrm{P}^{i} \mathrm{Pr}_{2}\right)_{2}\right), 131.4$, 129.6 (both s, $\mathrm{CH}_{\text {arom }}$ ), 128.8 (vt, $\left.N=27.8, \mathrm{C}_{\text {ipso }}-\operatorname{xant}\left(\mathrm{P}^{i} \mathrm{Pr}_{2}\right)_{2}\right), 128.8$, 125.4 (both s, $\left.\mathrm{CH}_{\text {arom }}{ }^{-\mathrm{Xant}}\left(\mathrm{P}^{i} \mathrm{Pr}_{2}\right)_{2}\right), 124.5$ (vt, $N=4.8, \mathrm{CH}_{\text {arom }}{ }^{-}$ $\left.\operatorname{xant}\left(\mathrm{P}^{i} \mathrm{Pr}_{2}\right)_{2}\right), 114.1\left(\mathrm{~s}, \mathrm{CH}_{\text {arom }}\right), 34.6\left(\mathrm{~s}, \mathrm{C}\left(\mathrm{CH}_{3}\right)_{2}\right), 34.2\left(\mathrm{t}, J_{\mathrm{C}-\mathrm{P}}=0.8\right.$, $\left.C\left(\mathrm{CH}_{3}\right)_{2}\right), 29.5\left(\mathrm{vt}, N=17.9, \mathrm{PCH}\left(\mathrm{CH}_{3}\right)_{2}\right), 29.2(\mathrm{vt}, N=32.9$, $\left.\mathrm{PCH}\left(\mathrm{CH}_{3}\right)_{2}\right), 25.6\left(\mathrm{~s}, \mathrm{C}\left(\mathrm{CH}_{3}\right)_{2}\right), 22.5\left(\mathrm{t}, J_{\mathrm{C}-\mathrm{P}}=1.0, \mathrm{COCH}_{3}\right), 19.9$ (vt, $\left.N=6.9, \operatorname{PCH}\left(\mathrm{CH}_{3}\right)_{2}\right), 19.8\left(\mathrm{~s}, \operatorname{PCH}\left(\mathrm{CH}_{3}\right)_{2}\right), 18.5(\mathrm{vt}, N=6.8$, $\left.\mathrm{PCH}\left(\mathrm{CH}_{3}\right)_{2}\right), 18.5\left(\mathrm{~s}, \operatorname{PCH}\left(\mathrm{CH}_{3}\right)_{2}\right) .{ }^{31} \mathrm{P}\left\{{ }^{1} \mathrm{H}\right\}$ NMR $(121.43 \mathrm{MHz}$, $\left.\mathrm{C}_{6} \mathrm{D}_{6}, 298 \mathrm{~K}\right): \delta 46.3$ (s).

Reaction of $\operatorname{RuH}\left(\eta^{2}-\mathrm{H}_{2} \mathrm{BH}_{2}\right)\left\{\operatorname{xant}\left(\mathrm{P}^{i} \mathrm{Pr}_{2}\right)_{2}\right\}$ (4) with Benzophenone: Preparation of $\mathrm{RuH}\left\{\kappa^{2}-\mathrm{C}, \mathrm{O}-\left[\mathrm{C}_{6} \mathrm{H}_{4} \mathrm{C}(\mathrm{Ph}) \mathrm{O}\right]\right\}\left\{\operatorname{xant}\left(\mathrm{P}^{i} \operatorname{Pr}_{2}\right)_{2}\right\}$ (5). A solution of $4(70 \mathrm{mg}, 0.125 \mathrm{mmol})$ in toluene $(10 \mathrm{~mL})$ was treated with benzophenone $(45 \mathrm{mg}, 0.250 \mathrm{mmol})$ and 2-propanol $(10 \mu \mathrm{L}, 0.125 \mathrm{mmol})$. The mixture was stirred at $80{ }^{\circ} \mathrm{C}$ for $6 \mathrm{~h}$, and the color of the mixture changed from yellow to purple. After this time the mixture was cooled to room temperature and the solvent was dried in vacuo and dissolved in diethyl ether. The resulting purple solution is filtered through an alumina column and the filtrate is evaporated to dryness. Methanol $(2 \mathrm{~mL})$ was added to afford a purple solid that was washed with methanol $(3 \times 2 \mathrm{~mL})$, and finally was dried in vacuo. Yield: $55 \mathrm{mg}(61 \%)$. ${ }^{1} \mathrm{H}$ NMR spectra of the crude reaction mixture showed the presence of diphenylmethanol. Anal. Calcd. for $\mathrm{C}_{40} \mathrm{H}_{50} \mathrm{O}_{2} \mathrm{P}_{2} \mathrm{Ru}$ : C, 66.19; H, 6.94. Found: C, 65.82; H, 7.10. IR ( $\left.\mathrm{cm}^{-1}\right)$ : v(Ru-H) 1944 (s). ${ }^{1} \mathrm{H}$ NMR (300 MHz, $\left.\mathrm{C}_{6} \mathrm{D}_{6}, 298 \mathrm{~K}\right)$ : $\delta 8.54\left(\mathrm{~d}, J_{\mathrm{H}-\mathrm{H}}=8.0,1 \mathrm{H}, \mathrm{CH}_{\text {arom }}\right), 8.00\left(\mathrm{~d}, J_{\mathrm{H}-\mathrm{H}}=8.0,1 \mathrm{H}, \mathrm{CH}_{\text {arom }}\right)$, $7.94\left(\mathrm{~d}, J_{\mathrm{H}-\mathrm{H}}=6.9,2 \mathrm{H}, \mathrm{CH}_{\text {arom }}\right), 7.28-6.88\left(\mathrm{~m}, 10 \mathrm{H}, \mathrm{CH}_{\text {arom }}\right.$ and $\left.\mathrm{CH}_{\text {arom-Xant }}\left(\mathrm{P}^{i} \mathrm{Pr}_{2}\right)_{2}\right), 6.69\left(\mathrm{t}, J_{\mathrm{H}-\mathrm{H}}=6.9,1 \mathrm{H}, \mathrm{CH}_{\text {arom }}\right), 2.42(\mathrm{~m}, 2 \mathrm{H}$, $\left.\mathrm{PCH}\left(\mathrm{CH}_{3}\right)_{2}\right), 2.10\left(\mathrm{~m}, 2 \mathrm{H}, \mathrm{PCH}\left(\mathrm{CH}_{3}\right)_{2}\right), 1.37\left(\mathrm{~s}, 3 \mathrm{H}, \mathrm{CH}_{3}\right), 1.36$ (dvt, $\left.J_{\mathrm{H}-\mathrm{H}}=6.8, N=16.4,6 \mathrm{H}, \mathrm{PCH}\left(\mathrm{CH}_{3}\right)_{2}\right), 1.23\left(\mathrm{dvt}, J_{\mathrm{H}-\mathrm{H}}=6.8, N=14.3\right.$, $\left.6 \mathrm{H}, \mathrm{PCH}\left(\mathrm{CH}_{3}\right)_{2}\right), 1.10\left(\mathrm{~s}, 3 \mathrm{H}, \mathrm{CH}_{3}\right), 0.92\left(\mathrm{dvt}, J_{\mathrm{H}-\mathrm{H}}=7.1, N=13.7\right.$, $\left.6 \mathrm{H}, \mathrm{PCH}\left(\mathrm{CH}_{3}\right)_{2}\right), 0.76\left(\mathrm{dvt}, J_{\mathrm{H}-\mathrm{H}}=6.9, \mathrm{~N}=15.3,6 \mathrm{H}, \mathrm{PCH}\left(\mathrm{CH}_{3}\right)_{2}\right)$, $15.42\left(\mathrm{t}, J_{\mathrm{H}-\mathrm{P}}=26.1,1 \mathrm{H}, \mathrm{RuH}\right) .{ }^{13} \mathrm{C}\left\{{ }^{1} \mathrm{H}\right\} \operatorname{NMR}\left(75.47 \mathrm{MHz}, \mathrm{C}_{6} \mathrm{D}_{6}\right.$, $298 \mathrm{~K}): \delta 212.4\left(\mathrm{t}, J_{\mathrm{C}-\mathrm{P}}=8.4, \mathrm{RuC}\right), 195.7(\mathrm{~s}, \mathrm{CO}), 158.0(\mathrm{vt}$, $\left.N=14.3, C_{\text {arom }}-\operatorname{xant}\left(\mathrm{P}^{i} \operatorname{Pr}_{2}\right)_{2}\right), 147.7\left(\mathrm{~s}, \mathrm{CH}_{\text {arom }}\right), 144.9,138.8$ (both s, $\left.C_{\text {arom }}\right), 133.8\left(\mathrm{~s}, \mathrm{CH}_{\text {arom }}\right), 132.7\left(\mathrm{vt}, N=4.4, C_{\text {arom }}-\operatorname{Xant}\left(\mathrm{P}^{i} \operatorname{Pr}_{2}\right)_{2}\right), 132.1$ (s, $\left.C \mathrm{H}_{\text {arom-xant }}\left(\mathrm{P}^{i} \mathrm{Pr}_{2}\right)_{2}\right), 129.4,129.3,128.7$ (all s, $\mathrm{CH}_{\text {arom }}$ ), 128.1 (this resonance is masked by the resonance of $\left.\mathrm{C}_{6} \mathrm{D}_{6}, C_{i p s o}-\mathrm{Xant}\left(\mathrm{P}^{i} \mathrm{Pr}_{2}\right)_{2}\right)$, 127.5 (s, $\left.C \mathrm{H}_{\text {arom }}-\mathrm{Xant}\left(\mathrm{P}^{i} \mathrm{Pr}_{2}\right)_{2}\right), 125.7$ (s, $\left.\mathrm{CH}_{\text {arom }}\right), 124.4$ (vt, $N=3.9$, $C \mathrm{H}_{\text {arom }}$-xant $\left.\left(\mathrm{P}^{i} \mathrm{Pr}_{2}\right)_{2}\right), 116.0$ (s, $\left.\mathrm{CH}_{\text {arom }}\right), 34.8\left(\mathrm{~s}, \mathrm{C}\left(\mathrm{CH}_{3}\right)_{2}\right), 34.6$ (s, $\left.\mathrm{C}\left(\mathrm{CH}_{3}\right)_{2}\right), 29.3$ (vt, $\left.N=12.8, \quad \mathrm{PCH}\left(\mathrm{CH}_{3}\right)_{2}\right), 28.9 \quad$ (vt, $N=27.9$, 
$\left.\mathrm{PCH}\left(\mathrm{CH}_{3}\right)_{2}\right), 25.6\left(\mathrm{~s}, \mathrm{C}\left(\mathrm{CH}_{3}\right)_{2}\right), 20.1,20.0$ (both s, $\left.\mathrm{PCH}\left(\mathrm{CH}_{3}\right)_{2}\right), 19.0$ (vt, $\left.N=9.2, \quad \operatorname{PCH}\left(\mathrm{CH}_{3}\right)_{2}\right), \quad 18.8 \quad$ (s, $\left.\quad \mathrm{PCH}\left(\mathrm{CH}_{3}\right)_{2}\right) .{ }^{31} \mathrm{P}\left\{{ }^{1} \mathrm{H}\right\} \mathrm{NMR}$ $\left(121.43 \mathrm{MHz}, \mathrm{C}_{6} \mathrm{D}_{6}, 298 \mathrm{~K}\right): \delta 62.8(\mathrm{~s})$

Reaction of $\operatorname{RuH}\left(\eta^{2}-\mathrm{H}_{2} \mathrm{BH}_{2}\right)\left\{\operatorname{xant}\left(\mathrm{P}^{i} \mathrm{Pr}_{2}\right)_{2}\right\}$ (4) with Perdeuterated Benzophenone. This reaction was carried out analogously as described for $\mathbf{5}$, starting from 4 (70 $\mathrm{mg}, 0.125 \mathrm{mmol})$ and perdeuterated benzophenone $(48.1 \mathrm{mg}, 0.250 \mathrm{mmol})$. Purple solid. Yield: 50 mg. ${ }^{1} \mathrm{H}$ NMR $\left(300 \mathrm{MHz}, \mathrm{C}_{6} \mathrm{D}_{6}, 298 \mathrm{~K}\right.$, aromatic and hydride region, integrals with respect to one of the $\mathrm{PCH}\left(\mathrm{CH}_{3}\right)_{2}$ signals $\left.(2 \mathrm{H})\right): \delta 8.54$ $\left(\mathrm{d}, J_{\mathrm{H}-\mathrm{H}}=8.0,0.6 \mathrm{H}, \mathrm{CH}_{\text {arom }}\right), 8.00\left(\mathrm{~d}, J_{\mathrm{H}-\mathrm{H}}=8.1,0.2 \mathrm{H}, \mathrm{CH}_{\text {arom }}\right), 7.95$ $\left(\mathrm{d}, J_{\mathrm{H}-\mathrm{H}}=7.0,0.4 \mathrm{H}, \mathrm{CH}_{\text {arom }}\right),-15.42\left(\mathrm{t}, J_{\mathrm{H}-\mathrm{P}}=26.1,0.5 \mathrm{H}, \mathrm{RuH}\right)$.

Reaction of $\operatorname{RuH}\left(\eta^{2}-\mathrm{H}_{2} \mathrm{BH}_{2}\right)\left\{\operatorname{xant}\left(\mathrm{P}^{i} \mathrm{Pr}_{2}\right)_{2}\right\}$ (4) with Acetophenone: Preparation of $\mathrm{RuH}\left\{\boldsymbol{\kappa}^{2}-\mathrm{C}, \mathrm{O}-\left[\mathrm{C}_{6} \mathrm{H}_{4} \mathrm{C}\left(\mathrm{CH}_{3}\right) \mathrm{O}\right]\right\}\left\{\operatorname{xant}\left(\mathrm{P}^{i} \mathrm{Pr}_{2}\right)_{2}\right\}$ (6). This complex was prepared analogously as described for $\mathbf{5}$ starting from 4 (75 mg, $0.134 \mathrm{mmol})$, acetophenone $(31 \mu \mathrm{L}, 0.268 \mathrm{mmol})$ and 2-propanol $(10 \mu \mathrm{L}, 0.134 \mathrm{mmol})$. Dark red solid. Yield: $46 \mathrm{mg}$ (52\%). ${ }^{1} \mathrm{H}$ NMR spectra of the crude reaction mixture showed the presence of 1-phenylethanol. Anal. Calcd. for $\mathrm{C}_{35} \mathrm{H}_{48} \mathrm{O}_{2} \mathrm{P}_{2} \mathrm{Ru}$ : C, 63.06; H, 6.35. Found: C, 62.75; H, 6.51. HRMS (electrospray, $\mathrm{m} / \mathrm{z}$ ): calcd. for $\mathrm{C}_{35} \mathrm{H}_{47} \mathrm{O}_{2} \mathrm{P} 2 \mathrm{Ru}[\mathrm{M}-\mathrm{H}]^{+}: 663.2099$, found: 663.2052. IR $\left(\mathrm{cm}^{-1}\right): v(\mathrm{Ru}-\mathrm{H}) 2030(\mathrm{~s}) .{ }^{1} \mathrm{H}$ NMR $\left(300 \mathrm{MHz}, \mathrm{C}_{6} \mathrm{D}_{6}, 298 \mathrm{~K}\right): \delta 8.43$ $\left(\mathrm{d}, J_{\mathrm{H}-\mathrm{H}}=8.1,1 \mathrm{H}, \mathrm{CH}_{\mathrm{arom}}\right), 7.75\left(\mathrm{~m}, 1 \mathrm{H}, \mathrm{CH}_{\text {arom }}\right), 7.66\left(\mathrm{~d}, J_{\mathrm{H}-\mathrm{H}}=8.1\right.$, $\left.1 \mathrm{H}, \mathrm{CH}_{\text {arom }}\right), 7.23\left(\mathrm{~m}, 2 \mathrm{H}, \mathrm{CH}_{\text {arom }}-\mathrm{xant}\left(\mathrm{P}^{i} \mathrm{Pr}_{2}\right)_{2}\right), 7.14-6.87(\mathrm{~m}, 4 \mathrm{H}$, $\mathrm{CH}_{\text {arom }}$-Xant $\left.\left(\mathrm{P}^{i} \mathrm{Pr}_{2}\right)_{2}\right), 6.71\left(\mathrm{t}, J_{\mathrm{H}-\mathrm{H}}=8.1,1 \mathrm{H}, \mathrm{CH}_{\text {arom }}\right), 2.50\left(\mathrm{t}, J_{\mathrm{H}-}\right.$ $\left.\mathrm{p}=1.5,3 \mathrm{H}, \mathrm{COCH}_{3}\right), 2.40\left(\mathrm{~m}, 2 \mathrm{H}, \mathrm{PCH}\left(\mathrm{CH}_{3}\right)_{2}\right), 1.91(\mathrm{~m}, 2 \mathrm{H}$, $\left.\mathrm{PCH}\left(\mathrm{CH}_{3}\right)_{2}\right), 1.37\left(\mathrm{~s}, 3 \mathrm{H}, \mathrm{CH}_{3}\right), 1.33\left(\mathrm{dvt}, J_{\mathrm{H}-\mathrm{H}}=6.9, N=16.2,6 \mathrm{H}\right.$, $\left.\mathrm{PCH}\left(\mathrm{CH}_{3}\right)_{2}\right), 1.20\left(\mathrm{dvt}, J_{\mathrm{H}-\mathrm{H}}=6.9, \mathrm{~N}=14.4,6 \mathrm{H}, \mathrm{PCH}\left(\mathrm{CH}_{3}\right)_{2}\right), 1.10$ (s, 3H, $\left.\mathrm{CH}_{3}\right), 0.95\left(\mathrm{dvt}, J_{\mathrm{H}-\mathrm{H}}=6.9, N=13.2,6 \mathrm{H}, \mathrm{PCH}\left(\mathrm{CH}_{3}\right)_{2}\right), 0.76$ $\left(\mathrm{dvt}, J_{\mathrm{H}-\mathrm{H}}=7.2, N=15.3,6 \mathrm{H}, \mathrm{PCH}\left(\mathrm{CH}_{3}\right)_{2}\right),-16.36\left(\mathrm{t}, J_{\mathrm{H}-\mathrm{P}}=27.0,1 \mathrm{H}\right.$, $\mathrm{RuH}) .{ }^{13} \mathrm{C}\left\{{ }^{1} \mathrm{H}\right\}$ NMR $\left(75.47 \mathrm{MHz}, \mathrm{C}_{6} \mathrm{D}_{6}, 298 \mathrm{~K}\right): \delta 209.0\left(\mathrm{t}, J_{\mathrm{C}-\mathrm{P}}\right.$ $=8.6, \mathrm{RuC}), 201.8\left(\mathrm{t}, J_{\mathrm{C}-\mathrm{P}}=2.1, \mathrm{CO}\right), 158.1$ (vt, $N=16.6, \mathrm{C}_{\text {arom }}{ }^{-}$ $\left.\operatorname{xant}\left(\mathrm{P}^{i} \mathrm{Pr}_{2}\right)_{2}\right), 147.6$ (s, $\left.\mathrm{CH}_{\text {arom }}\right), 142.9$ (s, $\left.\mathrm{C}_{\text {arom }}\right), 132.6$ (vt, $N=4.3$, $\mathrm{C}_{\text {arom- }}$-Xant $\left.\left(\mathrm{P}^{i} \mathrm{Pr}_{2}\right)_{2}\right), 131.2\left(\mathrm{~s}, \mathrm{CH}_{\text {arom }}\right), 129.1,128.7$ (both s, $\mathrm{CH}_{\text {arom }}{ }^{-}$ $\left.\operatorname{xant}\left(\mathrm{P}^{i} \mathrm{Pr}_{2}\right)_{2}\right), 128.2$ (this resonance is masked by the resonance of $\mathrm{C}_{6} \mathrm{D}_{6}, \quad \mathrm{C}_{i p s o}$-xant $\left.\left(\mathrm{P}^{i} \mathrm{Pr}_{2}\right)_{2}\right), 126.3 \quad\left(\mathrm{~s}, \quad \mathrm{CH}_{\text {arom }}\right), 124.3 \quad\left(\mathrm{~s}, \mathrm{CH}_{\text {arom- }}\right.$ xant $\left.\left(\mathrm{P}^{i} \mathrm{Pr}_{2}\right)_{2}\right), 115.5\left(\mathrm{~s}, \mathrm{CH}_{\text {arom }}\right), 34.7\left(\mathrm{~s}, \mathrm{C}\left(\mathrm{CH}_{3}\right)_{2}\right), 34.6\left(\mathrm{~s}, \mathrm{C}\left(\mathrm{CH}_{3}\right)_{2}\right)$, $30.5\left(\mathrm{~s}, \mathrm{COCH}_{3}\right), 29.2$ (vt, $\left.N=12.1, \mathrm{PCH}\left(\mathrm{CH}_{3}\right)_{2}\right), 28.9$ (vt, $N=27.9$, $\left.\mathrm{PCH}\left(\mathrm{CH}_{3}\right)_{2}\right), 26.1\left(\mathrm{~s}, \mathrm{C}\left(\mathrm{CH}_{3}\right)_{2}\right), 20.1$ (vt, $\left.N=7.5, \mathrm{PCH}\left(\mathrm{CH}_{3}\right)_{2}\right), 19.9$ (s, $\left.\mathrm{PCH}\left(\mathrm{CH}_{3}\right)_{2}\right), 19.1$ (vt, $\left.N=9.8, \operatorname{PCH}\left(\mathrm{CH}_{3}\right)_{2}\right), 18.8\left(\mathrm{~s}, \mathrm{PCH}\left(\mathrm{CH}_{3}\right)_{2}\right)$. ${ }^{31} \mathrm{P}\left\{{ }^{1} \mathrm{H}\right\}$ NMR (121.43 MHz, $\left.\mathrm{C}_{6} \mathrm{D}_{6}, 298 \mathrm{~K}\right): \delta 62.1$ (s).

Reaction of $\mathrm{OsH}_{4}\left\{\operatorname{xant}\left(\mathrm{P}^{i} \mathrm{Pr}_{2}\right)_{2}\right\}$ (1) with 2-Fluoroacetophenone: Preparation of $\mathrm{OsH}\left\{\boldsymbol{K}^{2}-\mathrm{C}, \mathrm{O}-\left[\mathrm{C}_{6} \mathrm{H}_{3} \mathrm{FC}(\mathrm{Me}) \mathrm{O}\right]\right\}\left\{\operatorname{xant}\left(\mathrm{P}^{i} \mathrm{Pr}_{2}\right)_{2}\right\} \quad(7)$. This complex was prepared analogously as described for $\mathbf{2}$ starting from $1(80 \mathrm{mg}, 0.126 \mathrm{mmol})$ and 2-fluoroacetophenone $(16 \mu \mathrm{L}, 0.126$ mmol). Dark red solid. Yield: $29 \mathrm{mg}$ (30\%). Anal. Calcd. for $\mathrm{C}_{35} \mathrm{H}_{47} \mathrm{FO}_{2} \mathrm{OsP}_{2}$ : C, 54.53; H, 6.14. Found: $\mathrm{C}, 54.32 ; \mathrm{H}, 6.38$. HRMS (electrospray, m/z): calcd. for $\mathrm{C}_{35} \mathrm{H}_{46} \mathrm{FO}_{3} \mathrm{OsP}_{2}[\mathrm{M}-\mathrm{H}+\mathrm{O}]^{+}$: 787.2517, found: 787.2638. IR $\left(\mathrm{cm}^{-1}\right): \mathrm{v}(\mathrm{Os}-\mathrm{H}) 2034$ (s). ${ }^{1} \mathrm{H}$ NMR $\left(400 \mathrm{MHz}, \mathrm{C}_{6} \mathrm{D}_{6}, 298 \mathrm{~K}\right): \delta 8.17\left(\mathrm{~d}, J_{\mathrm{H}-\mathrm{H}}=8.1,1 \mathrm{H}, \mathrm{CH}_{\text {arom }}\right), 7.16-6.96$ $\left(\mathrm{m}, \quad 4 \mathrm{H}, \quad \mathrm{CH}_{\text {arom }}-\mathrm{xant}\left(\mathrm{P}^{i} \mathrm{Pr}_{2}\right)_{2}\right), 6.88$ (t, $J_{\mathrm{H}-\mathrm{H}}=7.6,2 \mathrm{H}, \quad \mathrm{CH}_{\text {arom- }}{ }^{-}$ $\left.\operatorname{xant}\left(\mathrm{P}^{i} \mathrm{Pr}_{2}\right)_{2}\right), 6.61\left(\mathrm{dt}, J_{\mathrm{H}-\mathrm{H}}=6.8, J_{\mathrm{H}-\mathrm{F}}=7.6,1 \mathrm{H}, \mathrm{CH}_{\text {arom }}\right), 6.33\left(\mathrm{dd}, J_{\mathrm{H}-}\right.$ $\left.\mathrm{H}=7.6, J_{\mathrm{H}-\mathrm{F}}=12.4,1 \mathrm{H}, \mathrm{CH}_{\text {arom }}\right), 3.09\left(\mathrm{~d}, J_{\mathrm{H}-\mathrm{F}}=3.6,3 \mathrm{H}, \mathrm{COCH}_{3}\right)$, $2.40\left(\mathrm{~m}, 2 \mathrm{H}, \mathrm{PCH}\left(\mathrm{CH}_{3}\right)_{2}\right), 2.19\left(\mathrm{~m}, 2 \mathrm{H}, \mathrm{PCH}\left(\mathrm{CH}_{3}\right)_{2}\right), 1.36(\mathrm{~s}, 3 \mathrm{H}$, $\left.\mathrm{CH}_{3}\right), 1.29\left(\mathrm{dvt}, J_{\mathrm{H}-\mathrm{H}}=8.4, N=16.0,6 \mathrm{H}, \mathrm{PCH}\left(\mathrm{CH}_{3}\right)_{2}\right), 1.16\left(\mathrm{dvt}, J_{\mathrm{H}-\mathrm{H}}\right.$ $\left.=7.2, N=14.4,6 \mathrm{H}, \mathrm{PCH}\left(\mathrm{CH}_{3}\right)_{2}\right), 1.10\left(\mathrm{~s}, 3 \mathrm{H}, \mathrm{CH}_{3}\right), 0.91\left(\mathrm{dvt}, J_{\mathrm{H}-\mathrm{H}}=\right.$ $\left.6.8, N=13.6,6 \mathrm{H}, \mathrm{PCH}\left(\mathrm{CH}_{3}\right)_{2}\right), 0.74\left(\mathrm{dvt}, J_{\mathrm{H}-\mathrm{H}}=8.4, N=15.2,6 \mathrm{H}\right.$, $\left.\mathrm{PCH}\left(\mathrm{CH}_{3}\right)_{2}\right),-17.83\left(\mathrm{t}, J_{\mathrm{H}-\mathrm{P}}=22.8,1 \mathrm{H}, \mathrm{OsH}\right) .{ }^{13} \mathrm{C}\left\{{ }^{1} \mathrm{H}\right\}$ NMR $(100$ $\left.\mathrm{MHz}, \mathrm{C}_{6} \mathrm{D}_{6}, 298 \mathrm{~K}\right): \delta 205.5(\mathrm{~s}, \mathrm{CO}), 188.5\left(\mathrm{dt}, J_{\mathrm{C}-\mathrm{F}}=4.2, J_{\mathrm{C}-\mathrm{P}}=4.1\right.$, OsC), 166.5 (d, $\left.J_{\text {C-F }}=256.3, \mathrm{C}-\mathrm{F}\right), 159.3\left(\mathrm{vt}, N=13.1, \mathrm{C}_{\text {arom }}{ }^{-}\right.$ $\left.\operatorname{xant}\left(\mathrm{P}^{\mathrm{i}} \mathrm{Pr}_{2}\right)_{2}\right) 145.6\left(\mathrm{~d}, J_{\mathrm{C}-\mathrm{F}}=2.5, \mathrm{CH}_{\text {arom }}\right), 132.5\left(\mathrm{vt}, N=5.3, \mathrm{C}_{\text {arom- }}\right.$ $\left.\operatorname{xant}\left(\mathrm{P}^{i} \mathrm{Pr}_{2}\right)_{2}\right), 131.1\left(\mathrm{~d}, J_{\mathrm{C}-\mathrm{F}}=5.1, \mathrm{C}_{\text {arom }}\right), 130.8\left(\mathrm{~d}, J_{\mathrm{C}-\mathrm{F}}=9.6, \mathrm{CH}_{\text {arom }}\right)$, $129.1\left(\mathrm{~s}, \mathrm{CH}_{\text {arom }}\right.$-xant $\left.\left(\mathrm{P}^{i} \mathrm{Pr}_{2}\right)_{2}\right), 128.6\left(\mathrm{vt}, N=28.7, \mathrm{C}_{\text {ipso }}\right.$-xant $\left.\left(\mathrm{P}^{i} \mathrm{Pr}_{2}\right)_{2}\right)$, 125.8 (s, $\mathrm{CH}_{\text {arom }}$-Xant $\left.\left(\mathrm{P}^{i} \mathrm{Pr}_{2}\right)_{2}\right), 124.8$ (vt, $N=4.6, \mathrm{CH}_{\text {arom }}$-xant $\left.\left(\mathrm{P}^{i} \mathrm{Pr}_{2}\right)_{2}\right)$, $99.1\left(\mathrm{~d}, J_{\mathrm{C}-\mathrm{F}}=21.9, \mathrm{CH}_{\text {arom }}\right), 34.8\left(\mathrm{~s}, \mathrm{C}\left(\mathrm{CH}_{3}\right)_{2}\right), 34.5\left(\mathrm{~s}, \mathrm{C}\left(\mathrm{CH}_{3}\right)_{2}\right), 29.5$ (vt, $\left.N=18.7, \mathrm{PCH}\left(\mathrm{CH}_{3}\right)_{2}\right), 29.1$ (vt, $\left.N=33.3, \mathrm{PCH}\left(\mathrm{CH}_{3}\right)_{2}\right), 27.7$ (d, $\left.J_{\mathrm{C}-\mathrm{F}}=9.1, \mathrm{COCH}_{3}\right), 25.8\left(\mathrm{~s}, \mathrm{C}\left(\mathrm{CH}_{3}\right)_{2}\right), 19.9\left(\mathrm{~s}, \mathrm{PCH}\left(\mathrm{CH}_{3}\right)_{2}\right), 19.8$ (vt, $\left.N=6.4, \operatorname{PCH}\left(\mathrm{CH}_{3}\right)_{2}\right), 18.7\left(\mathrm{vt}, N=7.4, \operatorname{PCH}\left(\mathrm{CH}_{3}\right)_{2}\right), 18.5(\mathrm{~s}$, $\left.\mathrm{PCH}\left(\mathrm{CH}_{3}\right)_{2}\right) .{ }^{31} \mathrm{P}\left\{{ }^{1} \mathrm{H}\right\}$ NMR $\left(121.43 \mathrm{MHz}, \mathrm{C}_{6} \mathrm{D}_{6}, 298 \mathrm{~K}\right): \delta 46.2(\mathrm{~s})$. ${ }^{19} \mathrm{~F}\left\{{ }^{1} \mathrm{H}\right\}$ NMR (282.33 MHz, $\left.\mathrm{C}_{6} \mathrm{D}_{6}, 298 \mathrm{~K}\right): \delta-113.4(\mathrm{~s})$.
Reaction of $\mathrm{OsH}_{4}\left\{\operatorname{xant}\left(\mathrm{P}^{i} \mathrm{Pr}_{2}\right)_{2}\right\} \quad$ (1) with 2,6Difluorobenzophenone: Preparation of $\mathrm{OsH}\left\{\kappa^{2}-\mathrm{C}, \mathrm{O}-\right.$ $\left.\left\{\mathbf{C}_{6} \mathbf{H}_{4} \mathbf{C}\left(\mathbf{C}_{6} \mathbf{H}_{3} \mathbf{F}_{2}\right) \mathbf{O}\right]\right\}\left\{\operatorname{xant}\left(\mathbf{P}^{i} \mathbf{P r}_{2}\right)_{2}\right\}$ (8). This complex was prepared analogously as described for 2 starting from $1(60 \mathrm{mg}, 0.094 \mathrm{mmol})$ and 2,6-difluorobenzophenone (18 $\mu \mathrm{L}, 0.094 \mathrm{mmol})$. Purple solid. Yield: $58 \mathrm{mg}$ (72\%). Anal. Calcd. for $\mathrm{C}_{40} \mathrm{H}_{48} \mathrm{~F}_{2} \mathrm{O}_{2} \mathrm{OsP}_{2}$ : C, 56.42; $\mathrm{H}$, 5.69. Found: C, 56.12; H, 6.02. HRMS (electrospray, $\mathrm{m} / \mathrm{z}$ ): calcd. for $\mathrm{C}_{40} \mathrm{H}_{47} \mathrm{~F}_{2} \mathrm{O}_{2} \mathrm{OsP}_{2}[\mathrm{M}-\mathrm{H}]^{+}$: 851.2631, found: 851.2669. IR $\left(\mathrm{cm}^{-1}\right)$ : $v(\mathrm{Os}-\mathrm{H}) 2096(\mathrm{~m}) .{ }^{1} \mathrm{H}$ NMR $\left(300 \mathrm{MHz}, \mathrm{C}_{6} \mathrm{D}_{6}, 298 \mathrm{~K}\right): \delta 8.50\left(\mathrm{~d}, J_{\mathrm{H}-\mathrm{H}}\right.$ $\left.=7.5,1 \mathrm{H}, \mathrm{CH}_{\text {arom }}\right), 7.69\left(\mathrm{~d}, J_{\mathrm{H}-\mathrm{H}}=7.5,1 \mathrm{H}, \mathrm{CH}_{\text {arom }}\right), 7.18(\mathrm{~m}, 2 \mathrm{H}, 2$ $\mathrm{CH}_{\text {arom }}$-xant $\left.\left(\mathrm{P}^{i} \mathrm{Pr}_{2}\right)_{2}\right), 6.96\left(\mathrm{~d}, J_{\mathrm{H}-\mathrm{H}}=7.5,2 \mathrm{H}, \mathrm{CH}_{\text {arom }}\right.$-xant $\left.\left(\mathrm{P}^{i} \mathrm{Pr}_{2}\right)_{2}\right)$, $6.86\left(\mathrm{t}, J_{\mathrm{H}-\mathrm{H}}=7.5,2 \mathrm{H}, \mathrm{CH}_{\text {arom }}-\mathrm{Xant}\left(\mathrm{P}^{i} \mathrm{Pr}_{2}\right)_{2}\right), 6.71\left(\mathrm{t}, J_{\mathrm{H}-\mathrm{H}}=7.5,1 \mathrm{H}\right.$, $\left.\mathrm{CH}_{\text {arom }}\right), 6.57\left(\mathrm{~m}, 4 \mathrm{H}, \mathrm{CH}_{\text {arom }}\right), 2.47\left(\mathrm{~m}, 2 \mathrm{H}, \mathrm{PCH}\left(\mathrm{CH}_{3}\right)_{2}\right), 2.25(\mathrm{~m}$, $\left.2 \mathrm{H}, \mathrm{PC}\left(\mathrm{CH}_{3}\right)_{2}\right), 1.37\left(\mathrm{~s}, 3 \mathrm{H}, \mathrm{CH}_{3}\right), 1.29\left(\mathrm{dvt}, J_{\mathrm{H}-\mathrm{H}}=8.7, N=16.2\right.$, $\left.6 \mathrm{H}, \mathrm{PCH}\left(\mathrm{CH}_{3}\right)_{2}\right), 1.21\left(\mathrm{dvt}, J_{\mathrm{H}-\mathrm{H}}=7.5, N=14.7,6 \mathrm{H}, \mathrm{PCH}\left(\mathrm{CH}_{3}\right)_{2}\right)$, $1.06\left(\mathrm{~s}, 3 \mathrm{H}, \mathrm{CH}_{3}\right), 1.00\left(\mathrm{dvt}, J_{\mathrm{H}-\mathrm{H}}=6.6, N=13.4,6 \mathrm{H}, \mathrm{PCH}\left(\mathrm{CH}_{3}\right)_{2}\right)$, $0.88\left(\mathrm{dvt}, J_{\mathrm{H}-\mathrm{H}}=8.4, N=15.6,6 \mathrm{H}, \mathrm{PCH}\left(\mathrm{CH}_{3}\right)_{2}\right),-17.33\left(\mathrm{t}, J_{\mathrm{H}-\mathrm{P}}=23.9\right.$, $1 \mathrm{H}, \mathrm{OsH}) .{ }^{13} \mathrm{C}\left\{{ }^{1} \mathrm{H}\right\}$ NMR $\left(75.47 \mathrm{MHz}, \mathrm{C}_{6} \mathrm{D}_{6}, 298 \mathrm{~K}\right): \delta 194.5\left(\mathrm{t}, J_{\mathrm{C}-\mathrm{P}}\right.$ $=2.2, \mathrm{CO}), 188.1\left(\mathrm{t}, J_{\mathrm{C}-\mathrm{P}}=3.7, \mathrm{OsC}\right), 161.0\left(\mathrm{dd}, J_{\mathrm{C}-\mathrm{F}}=249.1, J_{\mathrm{C}-\mathrm{P}}=\right.$ 7.3, C-F), 160.0 ( $\mathrm{m}, \mathrm{C}_{\text {arom }}$ and $\mathrm{C}_{\text {arom }}$-Xant $\left.\left(\mathrm{P}^{i} \mathrm{Pr}_{2}\right)_{2}\right), 149.6\left(\mathrm{~s}, \mathrm{CH}_{\text {arom }}\right)$, $142.6\left(\mathrm{~s}, \mathrm{C}_{\text {arom }}\right), 133.2\left(\mathrm{~s}, \mathrm{CH}_{\text {arom }}\right), 133.1\left(\mathrm{~s}, \mathrm{C}_{\text {arom }}\right.$-Xant $\left.\left(\mathrm{P}^{i} \mathrm{Pr}_{2}\right)_{2}\right), 130.1$ $\left(\mathrm{t}, J_{\mathrm{C}-\mathrm{F}}=19.7, \mathrm{CH}_{\text {arom }}\right), 129.7\left(\mathrm{~s}, \mathrm{CH}_{\text {arom }}\right), 128.9\left(\mathrm{~s}, \mathrm{CH}_{\text {arom }}-\mathrm{xant}\left(\mathrm{P}^{i} \mathrm{Pr}_{2}\right)_{2}\right.$ 127.9 (this resonance is masked by the resonance of $\mathrm{C}_{6} \mathrm{D}_{6}, \mathrm{C}_{i p s 0^{-}}$ $\left.\operatorname{xant}\left(\mathrm{P}^{i} \mathrm{Pr}_{2}\right)_{2}\right), 125.3$ (s, $\left.\mathrm{CH}_{\text {arom }}-\operatorname{xant}\left(\mathrm{P}^{i} \mathrm{Pr}_{2}\right)_{2}\right), 124.9$ (vt, $N=4.6$, $\mathrm{CH}_{\text {arom }}$-xant $\left.\left(\mathrm{P}^{i} \mathrm{Pr}_{2}\right)_{2}\right), 115.4\left(\mathrm{~s}, \mathrm{CH}_{\text {arom }}\right), 111.5\left(\mathrm{~d}, J_{\mathrm{C}-\mathrm{F}}=25.4, \mathrm{CH}_{\text {arom }}\right)$, $34.8\left(\mathrm{~s}, \mathrm{C}\left(\mathrm{CH}_{3}\right)_{2}\right), 34.3\left(\mathrm{~s}, \mathrm{C}\left(\mathrm{CH}_{3}\right)_{2}\right), 28.7$ (vt, $\left.N=18.1, \mathrm{PCH}\left(\mathrm{CH}_{3}\right)_{2}\right)$, $28.5\left(\mathrm{vt}, N=29.5, \mathrm{PCH}\left(\mathrm{CH}_{3}\right)_{2}\right), 24.1\left(\mathrm{~s}, \mathrm{C}\left(\mathrm{CH}_{3}\right)_{2}\right), 20.0(\mathrm{~s}$, $\left.\operatorname{PCH}\left(\mathrm{CH}_{3}\right)_{2}\right), 19.6$ (vt, $\left.N=16.4, \operatorname{PCH}\left(\mathrm{CH}_{3}\right)_{2}\right), 18.8$ (vt, $N=8.6$, $\left.\mathrm{PCH}\left(\mathrm{CH}_{3}\right)_{2}\right), 18.2\left(\mathrm{~s}, \operatorname{PCH}\left(\mathrm{CH}_{3}\right)_{2}\right) .{ }^{31} \mathrm{P}\left\{{ }^{1} \mathrm{H}\right\}$ NMR $(121.43 \mathrm{MHz}$, $\left.\mathrm{C}_{6} \mathrm{D}_{6}, 298 \mathrm{~K}\right): \delta 48.5(\mathrm{~s}) .{ }^{19} \mathrm{~F}$ NMR $\left(282.33 \mathrm{MHz}, \mathrm{C}_{6} \mathrm{D}_{6}, 298 \mathrm{~K}\right): \delta-$ $109.2(\mathrm{~s})$.

Reaction of $\operatorname{RuH}\left(\eta^{2}-\mathrm{H}_{2} \mathrm{BH}_{2}\right)\left\{\operatorname{xant}\left(\mathrm{P}^{i} \mathrm{Pr}_{2}\right)_{2}\right\} \quad$ (4) with 2Fluoroacetophenone: Preparation of $\mathrm{RuH}\left\{\boldsymbol{K}^{2}-\mathrm{C}, \mathrm{O}-\right.$ $\left.\left[\mathrm{C}_{6} \mathrm{H}_{3} \mathbf{F C}(\mathrm{Me}) \mathrm{O}\right]\right\}\left\{\operatorname{xant}\left(\mathrm{P}^{i} \mathrm{Pr}_{2}\right)_{2}\right\} \quad$ (9). This complex was prepared analogously as described for $\mathbf{5}$ starting from $4(70 \mathrm{mg}, 0.125 \mathrm{mmol})$, 2-fluoroacetophenone (30 $\mu \mathrm{L}, 0.250 \mathrm{mmol})$ and 2-propanol $(10 \mu \mathrm{L}$, $0.125 \mathrm{mmol})$. Red solid. Yield: $32 \mathrm{mg}(38 \%) .{ }^{1} \mathrm{H}$ NMR spectra of the crude reaction mixture showed the presence of 1-(2fluorophenyl)ethanol. Anal. Calcd. for $\mathrm{C}_{35} \mathrm{H}_{47} \mathrm{FO}_{2} \mathrm{P}_{2} \mathrm{Ru}$ : C, 61.66; $\mathrm{H}$, 6.95. Found: $\mathrm{C}, 61.28 ; \mathrm{H}, 6.81$. HRMS (electrospray, $\mathrm{m} / \mathrm{z}$ ): calcd. for $\mathrm{C}_{35} \mathrm{H}_{46} \mathrm{FO}_{2} \mathrm{P} 2 \mathrm{Ru}[\mathrm{M}-\mathrm{H}]^{+}:$681.2005, found: 681.2014. IR $\left(\mathrm{cm}^{-1}\right)$ : $v(\mathrm{Ru}-\mathrm{H}) 2016(\mathrm{~s}) .{ }^{1} \mathrm{H}$ NMR $\left(300 \mathrm{MHz}, \mathrm{C}_{6} \mathrm{D}_{6}, 298 \mathrm{~K}\right): \delta 8.14\left(\mathrm{~d}, J_{\mathrm{H}-}\right.$ $\left.\mathrm{H}=7.8,1 \mathrm{H}, \mathrm{CH}_{\text {arom }}\right), 7.21\left(\mathrm{~m}, 2 \mathrm{H}, \mathrm{CH}_{\text {arom }}-\mathrm{Xant}\left(\mathrm{P}^{i} \mathrm{Pr}_{2}\right)_{2}\right), 7.02\left(\mathrm{dd}, J_{\mathrm{H}-}\right.$ $\left.\mathrm{H}=7.6, J_{\mathrm{H}-\mathrm{H}}=1.5,2 \mathrm{H}, \mathrm{CH}_{\text {arom }}-\mathrm{Xant}\left(\mathrm{P}^{i} \mathrm{Pr}_{2}\right)_{2}\right), 6.90\left(\mathrm{t}, J_{\mathrm{H}-\mathrm{H}}=7.5,2 \mathrm{H}\right.$, $\left.\mathrm{CH}_{\text {arom- }}-\mathrm{Xant}\left(\mathrm{P}^{i} \mathrm{Pr}_{2}\right)_{2}\right), 6.77\left(\mathrm{dt}, J_{\mathrm{H}-\mathrm{F}}=6.0, J_{\mathrm{H}-\mathrm{H}}=7.8,1 \mathrm{H}, \mathrm{CH}_{\text {arom }}\right), 6.33$ $\left(\mathrm{dd}, J_{\mathrm{H}-\mathrm{H}}=7.8, J_{\mathrm{H}-\mathrm{F}}=12.5,1 \mathrm{H}, \mathrm{CH}_{\mathrm{arom}}\right), 2.89\left(\mathrm{dt}, J_{\mathrm{H}-\mathrm{F}}=4.8, J_{\mathrm{H}-}\right.$ $\left.\mathrm{p}=1.6,3 \mathrm{H}, \quad \mathrm{CH}_{3}\right), 2.40\left(\mathrm{~m}, 2 \mathrm{H}, \mathrm{PCH}\left(\mathrm{CH}_{3}\right)_{2}\right), 2.07(\mathrm{~m}, 2 \mathrm{H}$, $\left.\mathrm{PCH}\left(\mathrm{CH}_{3}\right)_{2}\right), 1.36\left(\mathrm{~s}, 3 \mathrm{H}, \mathrm{CH}_{3}\right), 1.29\left(\mathrm{dvt}, J_{\mathrm{H}-\mathrm{H}}=6.9, N=16.5,6 \mathrm{H}\right.$, $\left.\mathrm{PCH}\left(\mathrm{CH}_{3}\right)_{2}\right), 1.21\left(\mathrm{dvt}, J_{\mathrm{H}-\mathrm{H}}=7.2, N=14.7,6 \mathrm{H}, \mathrm{PCH}\left(\mathrm{CH}_{3}\right)_{2}\right), 1.08$ (s, 3H, $\left.\mathrm{CH}_{3}\right), 0.94$ (dvt, $\left.J_{\mathrm{H}-\mathrm{H}}=6.9, N=13.5,6 \mathrm{H}, \mathrm{PCH}\left(\mathrm{CH}_{3}\right)_{2}\right), 0.77$ $\left(\mathrm{dvt}, J_{\mathrm{H}-\mathrm{H}}=6.9, N=15.6,6 \mathrm{H}, \mathrm{PCH}\left(\mathrm{CH}_{3}\right)_{2}\right),-16.11\left(\mathrm{t}, J_{\mathrm{H}-\mathrm{P}}=25.6\right.$, $\mathrm{RuH}) .{ }^{13} \mathrm{C}\left\{{ }^{1} \mathrm{H}\right\}$ NMR $\left(75.47 \mathrm{MHz}, \mathrm{C}_{6} \mathrm{D}_{6}, 298 \mathrm{~K}\right): \delta 213.7$ (dt, $J_{\mathrm{C}-}$ $\left.\mathrm{F}=6.0, J_{\mathrm{C}-\mathrm{P}}=8.3, \mathrm{RuC}\right), 200.0\left(\mathrm{dt}, J_{\mathrm{C}-\mathrm{F}}=6.0, J_{\mathrm{C}-\mathrm{P}}=1.5, \mathrm{CO}\right), 165.7$ (d, $\left.J_{\text {C-F }}=259.0, C-F\right), 158.1$ (vt, $N=14.3, \mathrm{C}_{\text {arom }}$ Xant $\left.\left(\mathrm{P}^{i} \mathrm{Pr}_{2}\right)_{2}\right), 143.3$ (d, $\left.J_{\mathrm{C}-\mathrm{F}}=2.3, \mathrm{CH}_{\text {arom }}\right), 132.7$ (vt, $N=5.3, \mathrm{C}_{\text {arom }}$-xant $\left.\left(\mathrm{P}^{i} \mathrm{Pr}_{2}\right)_{2}\right), 131.2$ (d, $\left.J_{\mathrm{C}-\mathrm{F}}=4.5, \mathrm{C}_{\text {arom }}\right), 130.4\left(\mathrm{~s}, \mathrm{CH}_{\text {arom }}\right), 129.1,128.7$ (both $\mathrm{s}, \mathrm{CH}_{\text {arom }}-$ xant $\left.\left(\mathrm{P}^{i} \mathrm{Pr}_{2}\right)_{2}\right), 127.1 \quad$ (vt, $\left.N=20.4, \mathrm{C}_{i p s o}-\operatorname{xant}\left(\mathrm{P}^{i} \mathrm{Pr}_{2}\right)_{2}\right), 124.4$ (vt, $\left.N=3.8, \mathrm{CH}_{\text {arom }}-\operatorname{xant}\left(\mathrm{P}^{i} \mathrm{Pr}_{2}\right)_{2}\right), 100.9\left(\mathrm{~d}, J_{\mathrm{C}-\mathrm{F}}=22.7, \mathrm{CH}_{\text {arom }}\right), 34.7(\mathrm{~s}$, $\left.C\left(\mathrm{CH}_{3}\right)_{2}\right), 34.5\left(\mathrm{~s}, \mathrm{C}\left(\mathrm{CH}_{3}\right)_{2}\right), 29.2\left(\mathrm{~d}, J_{\mathrm{C}-\mathrm{F}}=9.6, \mathrm{COCH}_{3}\right), 29.0$ (vt, $\left.N=12.9, \quad \mathrm{PCH}\left(\mathrm{CH}_{3}\right)_{2}\right), 28.6$ (vt, $\left.N=27.8, \quad \mathrm{PCH}\left(\mathrm{CH}_{3}\right)_{2}\right), 25.4$ (s, $\left.\mathrm{C}\left(\mathrm{CH}_{3}\right)_{2}\right), 20.0\left(\mathrm{~s}, \mathrm{PCH}\left(\mathrm{CH}_{3}\right)_{2}\right), 19.9$ (vt, $\left.N=7.6, \mathrm{PCH}\left(\mathrm{CH}_{3}\right)_{2}\right), 19.0$ (vt, $\left.N=9.0, \quad \operatorname{PCH}\left(\mathrm{CH}_{3}\right)_{2}\right), 18.7 \quad\left(\mathrm{~s}, \quad \operatorname{PCH}\left(\mathrm{CH}_{3}\right)_{2}\right) .{ }^{31} \mathrm{P}\left\{{ }^{1} \mathrm{H}\right\} \mathrm{NMR}$ $\left(121.43 \mathrm{MHz}, \mathrm{C}_{6} \mathrm{D}_{6}, 298 \mathrm{~K}\right): \delta 62.1$ (s). ${ }^{19} \mathrm{~F}$ NMR $\left(282.33 \mathrm{MHz}, \mathrm{C}_{6} \mathrm{D}_{6}\right.$, $298 \mathrm{~K}): \delta-109.1(\mathrm{~m})$.

Reaction of $\mathrm{OsH}_{4}\left\{\operatorname{xant}\left(\mathrm{P}^{i} \mathrm{Pr}_{2}\right)_{2}\right\}$ (1) with Benzylideneacetone: Preparation of $\mathrm{OsH}\left\{\boldsymbol{\kappa}^{2}-\mathrm{C}, \mathrm{O}-[\mathrm{C}(\mathrm{Ph}) \mathrm{CHC}(\mathrm{Me}) \mathrm{O}]\right\}\left\{\operatorname{xant}\left(\mathrm{P}^{i} \mathrm{Pr}_{2}\right)_{2}\right\}$ (10). A solution of $1(80 \mathrm{mg}, 0.126 \mathrm{mmol})$ in toluene $(10 \mathrm{~mL})$ was treated with benzylideneacetone $(37 \mathrm{mg}, 0.251 \mathrm{mmol})$ and the resulting mixture was heated to reflux overnight, getting a dark green solution. After being cooled at room temperature, the solution was 
evaporated to afford an oily residue. While cooling on a dry ice/ ${ }^{\mathrm{i}} \mathrm{PrOH}$ bath, addition of pentane $(2 \mathrm{~mL})$ afforded a dark green solid that was washed with pentane $(2 \times 2 \mathrm{~mL})$ and dried in vacuo. Yield: $88 \mathrm{mg}$ (90\%). Anal. Calcd. for $\mathrm{C}_{37} \mathrm{H}_{50} \mathrm{O}_{2} \mathrm{OsP}_{2}$ : C, 57.05; H, 6.47. Found: C, 56.84; H, 6.41. HRMS (electrospray, $\mathrm{m} / \mathrm{z}$ ): calcd. for $\mathrm{C}_{37} \mathrm{H}_{49} \mathrm{O}_{3} \mathrm{OsP}_{2}\left[\mathrm{M}-\mathrm{H}+\mathrm{O}^{+}:\right.$795.2768, found: 795.2732. IR $\left(\mathrm{cm}^{-1}\right)$ : $v(\mathrm{Os}-\mathrm{H}) 2050(\mathrm{w}) .{ }^{1} \mathrm{H}$ NMR $\left(300 \mathrm{MHz}, \mathrm{C}_{6} \mathrm{D}_{6}, 298 \mathrm{~K}\right): \delta 8.73\left(\mathrm{~d}, J_{\mathrm{H}-\mathrm{H}}\right.$ $\left.=7.3,2 \mathrm{H}, \mathrm{CH}_{\text {arom }}\right), 7.48\left(\mathrm{t}, J_{\mathrm{H}-\mathrm{H}}=6.0,1 \mathrm{H}, \mathrm{CH}_{\text {arom }}\right), 7.45(\mathrm{~s}, \mathrm{OsC}=\mathrm{CH})$, 7.36-7.27 (m, 4H, CH $\mathrm{CH}_{\text {arom }}$ and $\left.\mathrm{CH}_{\text {arom }}-\mathrm{Xant}\left(\mathrm{P}^{i} \mathrm{Pr}_{2}\right)_{2}\right), 7.09\left(\mathrm{dd}, J_{\mathrm{H}-\mathrm{H}}=\right.$ $\left.7.5, J_{\mathrm{H}-\mathrm{H}}=1.2,2 \mathrm{H}, \mathrm{CH}_{\text {arom }}-\mathrm{Xant}\left(\mathrm{P}^{i} \mathrm{Pr}_{2}\right)_{2}\right), 6.98\left(\mathrm{t}, J_{\mathrm{H}-\mathrm{H}}=7.5,2 \mathrm{H}, \mathrm{CH}_{\mathrm{a}-}\right.$ rom-Xant $\left.\left(\mathrm{P}^{i} \mathrm{Pr}_{2}\right)_{2}\right), 2.65\left(\mathrm{~m}, 2 \mathrm{H}, \mathrm{PCH}\left(\mathrm{CH}_{3}\right)_{2}\right), 2.59\left(\mathrm{t}, J_{\mathrm{H}-\mathrm{P}}=1.5,3 \mathrm{H}\right.$, $\left.\mathrm{COCH}_{3}\right) 2.49\left(\mathrm{~m}, 2 \mathrm{H}, \mathrm{PCH}\left(\mathrm{CH}_{3}\right)_{2}\right), 1.45,1.20$ (both s, 3H, $\left.\mathrm{CH}_{3}\right)$, 1.26-1.02 (dvts, overlapping, 24H, $\left.\mathrm{PCH}\left(\mathrm{CH}_{3}\right)_{2}\right)$, -17.11 (t, $J_{\mathrm{H}-\mathrm{P}}=23.4$, $1 \mathrm{H}, \mathrm{OsH}) .{ }^{13} \mathrm{C}\left\{{ }^{1} \mathrm{H}\right\} \mathrm{NMR}\left(75 \mathrm{MHz}, \mathrm{C}_{6} \mathrm{D}_{6}, 298 \mathrm{~K}\right): \delta 224.7\left(\mathrm{t}, J_{\mathrm{C}-\mathrm{P}}=\right.$ $3.2, \mathrm{OsC}), 194.5\left(\mathrm{t}, J_{\mathrm{C}-\mathrm{P}}=1.7, \mathrm{CO}\right), 158.0\left(\mathrm{vt}, N=13.1, \mathrm{C}_{\mathrm{arom}^{-}}\right.$ xant $\left.\left(\mathrm{P}^{i} \operatorname{Pr}_{2}\right)_{2}\right), 156.7$ (s, C $\left.\mathrm{C}_{\text {arom }}\right), 131.8\left(\mathrm{vt}, N=5.4, \mathrm{C}_{\text {arom }}-\mathrm{Xant}\left(\mathrm{P}^{i} \operatorname{Pr}_{2}\right)_{2}\right)$, 130.3 (s, $\left.\mathrm{CH}_{\text {arom }}\right), 129.2$ (s, $\left.\mathrm{CH}_{\text {arom }}-\operatorname{xant}\left(\mathrm{P}^{i} \mathrm{Pr}_{2}\right)_{2}\right), 128.4\left(\mathrm{~s}, \mathrm{CH}_{\text {arom }}\right)$, 127.9 (this resonance is masked by the resonance of $\mathrm{C}_{6} \mathrm{D}_{6}, \mathrm{C}_{\mathrm{ips} 0^{-}}$ $\left.\operatorname{xant}\left(\mathrm{P}^{i} \mathrm{Pr}_{2}\right)_{2}\right), 127.2\left(\mathrm{~s}, \mathrm{CH}_{\text {arom }}\right), 126.3\left(\mathrm{~s}, \mathrm{CH}_{\text {arom }}-\operatorname{xant}\left(\mathrm{P}^{i} \operatorname{Pr}_{2}\right)_{2}\right), 124.6$ (s, OsCCH), 124.4 (vt, $\left.N=4.9, \mathrm{CH}_{\text {arom }}-\mathrm{xant}\left(\mathrm{P}^{i} \mathrm{Pr}_{2}\right)_{2}\right), 34.7$ (s, $\left.\mathrm{C}\left(\mathrm{CH}_{3}\right)_{2}\right), 34.1\left(\mathrm{~s}, \mathrm{C}\left(\mathrm{CH}_{3}\right)_{2}\right), 29.1$ (vt, $\left.N=20.0, \mathrm{PCH}\left(\mathrm{CH}_{3}\right)_{2}\right), 28.7$ (vt, $\left.N=33.4, \mathrm{PCH}\left(\mathrm{CH}_{3}\right)_{2}\right), 27.2\left(\mathrm{~s}, \mathrm{C}\left(\mathrm{CH}_{3}\right)_{2}\right), 23.9\left(\mathrm{~s}, \mathrm{COCH}_{3}\right), 18.7$ (s, $\left.\operatorname{PCH}\left(\mathrm{CH}_{3}\right)_{2}\right), 18.5$ (vt, $\left.N=4.6, \operatorname{PCH}\left(\mathrm{CH}_{3}\right)_{2}\right), 18.1$ (vt, $N=7.7$, $\left.\mathrm{PCH}\left(\mathrm{CH}_{3}\right)_{2}\right), 17.9$ (s, $\left.\mathrm{PCH}\left(\mathrm{CH}_{3}\right)_{2}\right) .{ }^{31} \mathrm{P}\left\{{ }^{1} \mathrm{H}\right\}$ NMR $(121.43 \mathrm{MHz}$, $\left.\mathrm{C}_{6} \mathrm{D}_{6}, 298 \mathrm{~K}\right): \delta 46.8$ (s).

Reaction of $\mathrm{OsH}_{4}\left\{\operatorname{xant}\left(\mathrm{P}^{i} \operatorname{Pr}_{2}\right)_{2}\right\}$ (1) with Methyl Vinyl Ketone: Preparation of $\mathrm{OsH}\left\{\boldsymbol{\kappa}^{2}-\mathrm{C}, \mathrm{O}-[\mathrm{C}(\mathrm{H}) \mathrm{CHC}(\mathrm{Me}) \mathrm{O}]\right\}\left\{\operatorname{xant}\left(\mathrm{P}^{i} \operatorname{Pr}_{2}\right)_{2}\right\}$ (11). This complex was prepared analogously as described for $\mathbf{1 0}$ starting from $1(80 \mathrm{mg}, 0.126 \mathrm{mmol})$ and methyl vinyl ketone $(20 \mu \mathrm{L}$, $0.126 \mathrm{mmol})$. Dark green solid. Yield: $57 \mathrm{mg}$ (64\%). Anal. Calcd. for $\mathrm{C}_{31} \mathrm{H}_{46} \mathrm{O}_{2} \mathrm{OsP}_{2}$ : C, 52.97; H, 6.60. Found: C, 52.52; H, 7.07. HRMS (electrospray, $m / z$ ): calcd. for $\mathrm{C}_{31} \mathrm{H}_{45} \mathrm{O}_{2} \mathrm{OsP}_{2}[\mathrm{M}-\mathrm{H}]^{+}$: 703.2506, found: 703.2522. IR $\left(\mathrm{cm}^{-1}\right): \mathrm{v}(\mathrm{Os}-\mathrm{H}) 2035(\mathrm{w}) .{ }^{1} \mathrm{H}$ NMR $(300 \mathrm{MHz}$, $\left.\mathrm{C}_{6} \mathrm{D}_{6}, 298 \mathrm{~K}\right): \delta 14.05\left(\mathrm{dd}, J_{\mathrm{H}-\mathrm{H}}=6.3, J_{\mathrm{H}-\mathrm{H}}=1.5,1 \mathrm{H}, \mathrm{OsCH}\right), 7.17(\mathrm{~m}$, $2 \mathrm{H}, \mathrm{CH}_{\text {arom }}$-Xant $\left.\left(\mathrm{P}^{i} \mathrm{Pr}_{2}\right)_{2}\right), 7.00-6.96\left(\mathrm{~m}, 3 \mathrm{H}, \mathrm{CH}_{\text {arom }}-\mathrm{Xant}\left(\mathrm{P}^{i} \operatorname{Pr}_{2}\right)_{2}\right.$ and OsCHCH $), 6.91\left(\mathrm{t}, J_{\mathrm{H}-\mathrm{H}}=7.2,2 \mathrm{H}, \mathrm{CH}_{\text {arom }}\right.$-Xant $\left.\left(\mathrm{P}^{i} \mathrm{Pr}_{2}\right)_{2}\right), 2.58\left(\mathrm{t}, J_{\mathrm{H}-\mathrm{P}}=\right.$ $\left.1.2,3 \mathrm{H}, \mathrm{COCH}_{3}\right), 2.44\left(\mathrm{~m}, 2 \mathrm{H}, \mathrm{PCH}\left(\mathrm{CH}_{3}\right)_{2}\right), 2.26(\mathrm{~m}, 2 \mathrm{H}$, $\left.\mathrm{PCH}\left(\mathrm{CH}_{3}\right)_{2}\right), 1.48\left(\mathrm{~s}, 3 \mathrm{H}, \mathrm{CH}_{3}\right), 1.52-1.35$ (dvts, overlapping, $12 \mathrm{H}$, $\left.\mathrm{PCH}\left(\mathrm{CH}_{3}\right)_{2}\right), 1.20$ (s, 3H, $\left.\mathrm{CH}_{3}\right), 1.26-1.07$ (dvts, overlapping, 12H, $\left.\mathrm{PCH}\left(\mathrm{CH}_{3}\right)_{2}\right),-17.81\left(\mathrm{dt}, J_{\mathrm{H}-\mathrm{H}}=1.5, J_{\mathrm{H}-\mathrm{P}}=23.1,1 \mathrm{H}, \mathrm{OsH}\right)$. ${ }^{13} \mathrm{C}\left\{{ }^{1} \mathrm{H}\right\}$ NMR $\left(75 \mathrm{MHz}, \mathrm{C}_{6} \mathrm{D}_{6}, 298 \mathrm{~K}\right): \delta 213.8\left(\mathrm{t}, J_{\mathrm{C}-\mathrm{P}}=3.0, \mathrm{OsCH}\right)$, 193.5 (s, CO), 158.7 (vt, $\left.N=13.7, \mathrm{C}_{\text {arom }}-\mathrm{xant}\left(\mathrm{P}^{i} \operatorname{Pr}_{2}\right)_{2}\right), 132.6$ (vt, $N=$ 5.3, $\mathrm{C}_{\text {arom }}$-xant $\left.\left(\mathrm{P}^{i} \mathrm{Pr}_{2}\right)_{2}\right), 128.9\left(\mathrm{~s}, \mathrm{CH}_{\text {arom }}-\mathrm{xant}\left(\mathrm{P}^{i} \mathrm{Pr}_{2}\right)_{2}\right), 127.9$ (this resonance is masked by the resonance of $\left.\mathrm{C}_{6} \mathrm{D}_{6}, \mathrm{C}_{\mathrm{ipso}}-\mathrm{xant}\left(\mathrm{P}^{i} \mathrm{Pr}_{2}\right)_{2}\right)$, 125.5 (s, OsCHCH), 125.4 (s, $\mathrm{CH}_{\text {arom }}$-Xant $\left.\left(\mathrm{P}^{i} \mathrm{Pr}_{2}\right)_{2}\right), 124.7$ (vt, $N=4.3$, $\left.\mathrm{CH}_{\text {arom-xant }}\left(\mathrm{P}^{i} \mathrm{Pr}_{2}\right)_{2}\right), 34.5\left(\mathrm{~s}, \mathrm{C}\left(\mathrm{CH}_{3}\right)_{2}\right), 34.4\left(\mathrm{~s}, \mathrm{C}\left(\mathrm{CH}_{3}\right)_{2}\right), 31.3$ (vt, $N$ $\left.=19.9, \mathrm{PCH}\left(\mathrm{CH}_{3}\right)_{2}\right), 27.6\left(\mathrm{vt}, N=34.9, \mathrm{PCH}\left(\mathrm{CH}_{3}\right)_{2}\right), 24.6(\mathrm{~s}$, $\left.\mathrm{C}\left(\mathrm{CH}_{3}\right)_{2}\right), 23.3\left(\mathrm{~s}, \mathrm{COCH}_{3}\right), 20.5$ (vt, $\left.\mathrm{N}=9.8, \mathrm{PCH}\left(\mathrm{CH}_{3}\right)_{2}\right), 19.5$ (s, $\left.\operatorname{PCH}\left(\mathrm{CH}_{3}\right)_{2}\right), 18.7$ (vt, $\left.N=7.0, \operatorname{PCH}\left(\mathrm{CH}_{3}\right)_{2}\right), 18.5\left(\mathrm{~s}, \mathrm{PCH}\left(\mathrm{CH}_{3}\right)_{2}\right)$. ${ }^{31} \mathrm{P}\left\{{ }^{1} \mathrm{H}\right\}$ NMR $\left(121.43 \mathrm{MHz}, \mathrm{C}_{6} \mathrm{D}_{6}, 298 \mathrm{~K}\right): \delta 57.7(\mathrm{~s})$.

\section{Reaction of $\operatorname{RuH}\left(\eta^{2}-\mathrm{H}_{2} \mathrm{BH}_{2}\right)\left\{\operatorname{xant}\left(\mathrm{P}^{i} \mathbf{P r}_{2}\right)_{2}\right\}$ with Benzylidenea-} cetone: Preparation of $\quad$ RuH $\left\{\boldsymbol{x}^{2}-\mathrm{C}, \mathrm{O}\right.$ $[\mathbf{C}(\mathbf{P h}) \mathbf{C H C}(\mathrm{Me}) \mathrm{O}]\}\left\{\operatorname{xant}\left(\mathbf{P}^{i} \mathbf{P r}_{2}\right)_{2}\right\}$ (12). This complex was prepared analogously as described for 5 starting from 4 (80 $\mathrm{mg}, 0.143 \mathrm{mmol})$, benzylidenacetone (42 $\mathrm{mg}, 0.286 \mathrm{mmol})$ and 2-propanol $(11 \mu \mathrm{L}$, $0.143 \mathrm{mmol})$. Dark green solid. Yield: $74 \mathrm{mg}(75 \%)$. ${ }^{\mathrm{H}} \mathrm{H}$ NMR spectra of the crude reaction mixture showed the presence of 4-phenyl-2butanone Anal. Calcd. for $\mathrm{C}_{37} \mathrm{H}_{50} \mathrm{O}_{2} \mathrm{P}_{2} \mathrm{Ru}$ : C, 64.42; H, 7.31. Found: $\mathrm{C}$, 64.28; $\mathrm{H}$, 6.91. HRMS (electrospray, $\mathrm{m} / \mathrm{z}$ ): calcd. for $\mathrm{C}_{37} \mathrm{H}_{49} \mathrm{O}_{2} \mathrm{P}_{2} \mathrm{Ru}[\mathrm{M}-\mathrm{H}]^{+}:$689.2256, found: 689.2247. IR $\left(\mathrm{cm}^{-1}\right): v(\mathrm{Ru}-$ H) $1949(\mathrm{w}) .{ }^{1} \mathrm{H}$ NMR $\left(300 \mathrm{MHz}, \mathrm{C}_{6} \mathrm{D}_{6}, 298 \mathrm{~K}\right): \delta 8.50\left(\mathrm{~d}, J_{\mathrm{H}-\mathrm{H}}=7.1\right.$, $\left.2 \mathrm{H}, \mathrm{CH}_{\text {arom }}\right), 7.34\left(\mathrm{t}, J_{\mathrm{H}-\mathrm{H}}=7.2,2 \mathrm{H}, \mathrm{CH}_{\text {arom }}\right), 7.29(\mathrm{~s}, 1 \mathrm{H}, \mathrm{RuCCH})$, 7.23-6.98 (m, 5H, $\left.\mathrm{CH}_{\text {arom }}\right), 6.90\left(\mathrm{t}, \quad J_{\mathrm{H}-\mathrm{H}}=7.5,2 \mathrm{H}, \mathrm{CH}_{\text {arom }}{ }^{-}\right.$ $\left.\operatorname{xant}\left(\mathrm{P}^{i} \mathrm{Pr}_{2}\right)_{2}\right), 2.37,2.30$ (both $\left.\mathrm{m}, 4 \mathrm{H}, \mathrm{PCH}\left(\mathrm{CH}_{3}\right)_{2}\right), 1.56(\mathrm{~s}, 3 \mathrm{H}$, $\left.\mathrm{COCH}_{3}\right), 1.35\left(\mathrm{~s}, 3 \mathrm{H}, \mathrm{CH}_{3}\right), 1.13\left(\mathrm{dvt}, J_{\mathrm{H}-\mathrm{H}}=6.9, N=12.3,6 \mathrm{H}\right.$, $\left.\mathrm{PCH}\left(\mathrm{CH}_{3}\right)_{2}\right), 1.12\left(\mathrm{~s}, 3 \mathrm{H}, \mathrm{CH}_{3}\right), 1.10-0.95$ (3 dvt overlapped, $18 \mathrm{H}$, $\left.\mathrm{PCH}\left(\mathrm{CH}_{3}\right)_{2}\right),-15.35\left(\mathrm{t}, J_{\mathrm{H}-\mathrm{P}}=26.1,1 \mathrm{H}, \mathrm{RuH}\right) .{ }^{13} \mathrm{C}\left\{{ }^{1} \mathrm{H}\right\} \quad \mathrm{NMR}$ $\left(75.47 \mathrm{MHz}, \mathrm{C}_{6} \mathrm{D}_{6}, 298 \mathrm{~K}\right): \delta 255.0\left(\mathrm{t}, J_{\mathrm{C}-\mathrm{P}}=6.3, \mathrm{RuC}\right), 192.7\left(\mathrm{t}, J_{\mathrm{C}-}\right.$ $\mathrm{p}=2.3, \mathrm{CO}), 156.8\left(\mathrm{vt}, N=15.1, \mathrm{C}_{\mathrm{arom}}-\operatorname{xant}\left(\mathrm{P}^{i} \operatorname{Pr}_{2}\right)_{2}\right), 153.6\left(\mathrm{~s}, \mathrm{C}_{\mathrm{arom}}\right)$, 132.0 (vt, $\left.N=5.4, \mathrm{C}_{\text {arom }}-\operatorname{xant}\left(\mathrm{P}^{i} \operatorname{Pr}_{2}\right)_{2}\right), 130.0$ (s, $\left.\mathrm{CH}_{\text {arom }}-\mathrm{Xant}\left(\mathrm{P}^{i} \operatorname{Pr}_{2}\right)_{2}\right)$,
129.5, 127.3, 126.6 (all s, $\mathrm{CH}_{\text {arom }}$ ), 126.4 (s, $\left.\mathrm{CH}_{\text {arom }}-\mathrm{xant}\left(\mathrm{P}^{i} \mathrm{Pr}_{2}\right)_{2}\right)$, 126.3 (vt, $\left.N=20.2, \mathrm{C}_{i p s o}-\operatorname{xant}\left(\mathrm{P}^{i} \mathrm{Pr}_{2}\right)_{2}\right), 124.2$ (vt, $N=4.2, \mathrm{CH}_{\text {arom- }}$ xant $\left.\left(\mathrm{P}^{i} \mathrm{Pr}_{2}\right)_{2}\right), 123.6(\mathrm{~s}, \mathrm{RuCCH}), 34.8\left(\mathrm{~s}, \mathrm{C}\left(\mathrm{CH}_{3}\right)_{2}\right), 34.5\left(\mathrm{~s}, \mathrm{C}\left(\mathrm{CH}_{3}\right)_{2}\right)$, 28.5 (vt, $\left.N=14.3, \mathrm{PCH}\left(\mathrm{CH}_{3}\right)_{2}\right), 28.3$ (vt, $\left.N=27.9, \mathrm{PCH}\left(\mathrm{CH}_{3}\right)_{2}\right), 27.6$ (s, $\left.\mathrm{C}\left(\mathrm{CH}_{3}\right)_{2}\right), 25.4\left(\mathrm{~s}, \mathrm{COCH}_{3}\right), 19.0$ (vt, $\left.N=5.7, \mathrm{PCH}\left(\mathrm{CH}_{3}\right)_{2}\right), 18.9$ (s, $\left.\operatorname{PCH}\left(\mathrm{CH}_{3}\right)_{2}\right), 18.7$ (vt, $\left.N=9.1, \operatorname{PCH}\left(\mathrm{CH}_{3}\right)_{2}\right), 18.4 \quad$ (vt, $N=2.5$, $\left.\mathrm{PCH}\left(\mathrm{CH}_{3}\right)_{2}\right) .{ }^{31} \mathrm{P}\left\{{ }^{1} \mathrm{H}\right\}$ NMR $\left(121.43 \mathrm{MHz}, \mathrm{C}_{6} \mathrm{D}_{6}, 298 \mathrm{~K}\right): \delta 63.2$ (s).

Reaction of $\operatorname{RuH}\left(\eta^{2}-\mathrm{H}_{2} \mathrm{BH}_{2}\right)\left\{\operatorname{xant}\left(\mathrm{P}^{i} \operatorname{Pr}_{2}\right)_{2}\right\}$ (4) with Methyl Vinyl Ketone: Preparation of RuH $\left\{\boldsymbol{x}^{2}-\mathrm{C}, \mathrm{O}-\right.$ $[\mathbf{C}(\mathrm{H}) \mathrm{CHC}(\mathrm{Me}) \mathrm{O}]\}\left\{\operatorname{xant}\left(\mathbf{P}^{i} \mathbf{P r}_{2}\right)_{2}\right\}$ (13). This complex was prepared analogously as described for 5 starting from 4 (90 mg, $0.161 \mathrm{mmol})$, methyl vinyl ketone $(26 \mu \mathrm{L}, 0.322 \mathrm{mmol})$ and 2-propanol $(12 \mu \mathrm{L}$, $0.161 \mathrm{mmol})$. Dark yellow solid. Yield: $51 \mathrm{mg}(52 \%)$. ${ }^{1} \mathrm{H}$ NMR spectra of the crude reaction mixture showed the presence of 2butanone. Anal. Calcd. for $\mathrm{C}_{31} \mathrm{H}_{46} \mathrm{O}_{2} \mathrm{P}_{2} \mathrm{Ru}$ : C, 60.67; H, 7.55. Found: C, 60.35; H, 7.82. IR $\left(\mathrm{cm}^{-1}\right): v(\mathrm{Os}-\mathrm{H}) 1924$ (w). ${ }^{1} \mathrm{H}$ NMR $(300 \mathrm{MHz}$, $\left.\mathrm{C}_{6} \mathrm{D}_{6}, 298 \mathrm{~K}\right): \delta 12.67\left(\mathrm{dd}, J_{\mathrm{H}-\mathrm{H}}=6.0, J_{\mathrm{H}-\mathrm{H}}=1.0,1 \mathrm{H}, \mathrm{RuCH}\right), 7.12$ (m, 2H, CH arom-Xant $\left.\left(\mathrm{P}^{i} \mathrm{Pr}_{2}\right)_{2}\right), 7.07-7.00\left(\mathrm{~m}, 3 \mathrm{H}, \mathrm{CH}_{\text {arom }}-\mathrm{Xant}\left(\mathrm{P}^{i} \operatorname{Pr}_{2}\right)_{2} \mathrm{y}\right.$ $\mathrm{RuCHCH}), 6.91\left(\mathrm{t}, J_{\mathrm{H}-\mathrm{H}}=7.5,2 \mathrm{H}, \mathrm{CH}_{\text {arom }}-\mathrm{Xant}\left(\mathrm{P}^{i} \mathrm{Pr}_{2}\right)_{2}\right), 2.38\left(\mathrm{t}, J_{\mathrm{H}-}\right.$ $\left.\mathrm{P}=1.8,3 \mathrm{H}, \mathrm{COCH}_{3}\right), 2.22-2.10$ (both m, $\left.4 \mathrm{H}, \mathrm{PCH}\left(\mathrm{CH}_{3}\right)_{2}\right), 1.40(\mathrm{dvt}$, $\left.J_{\mathrm{H}-\mathrm{H}}=6.9, \mathrm{~N}=18.0,6 \mathrm{H}, \mathrm{PCH}\left(\mathrm{CH}_{3}\right)_{2}\right), 1.36,1.29$ (both s, $3 \mathrm{H}, \mathrm{CH}_{3}$ ), 1.11-1.01 (3 dvts overlapped, $\left.18 \mathrm{H}, \mathrm{PCH}\left(\mathrm{CH}_{3}\right)_{2}\right),-15.96\left(\mathrm{t}, J_{\mathrm{H}-\mathrm{P}}=\right.$ 26.1, 1H, RuH). ${ }^{13} \mathrm{C}\left\{{ }^{1} \mathrm{H}\right\} \mathrm{NMR}\left(75.47 \mathrm{MHz}, \mathrm{C}_{6} \mathrm{D}_{6}, 298 \mathrm{~K}\right): \delta 245.6(\mathrm{t}$, $\left.J_{\mathrm{C}-\mathrm{P}}=7.4, \mathrm{RuC}\right), 191.6(\mathrm{~s}, \mathrm{CO}), 157.9\left(\mathrm{vt}, N=15.7, \mathrm{C}_{\mathrm{arom}^{-}}\right.$ $\left.\operatorname{xant}\left(\mathrm{P}^{i} \mathrm{Pr}_{2}\right)_{2}\right), 133.0\left(\mathrm{vt}, N=5.6, \mathrm{C}_{\text {arom }}-\mathrm{xant}\left(\mathrm{P}^{i} \operatorname{Pr}_{2}\right)_{2}\right), 128.7\left(\mathrm{~s}, \mathrm{CH}_{\text {arom }^{-}}\right.$ $\left.\operatorname{xant}\left(\mathrm{P}^{i} \operatorname{Pr}_{2}\right)_{2}\right), 126.8\left(\mathrm{vt}, N=25.5, \mathrm{C}_{\text {ipso }}-\operatorname{xant}\left(\mathrm{P}^{i} \operatorname{Pr}_{2}\right)_{2}\right), 126.1(\mathrm{~s}$, $\mathrm{RuCHCH}), 125.5$ (s, $\left.\mathrm{CH}_{\text {arom }}-\mathrm{xant}\left(\mathrm{P}^{i} \mathrm{Pr}_{2}\right)_{2}\right), 124.4$ (vt, $N=4.3, \mathrm{CH}_{\text {arom }}{ }^{-}$ xant $\left.\left(\mathrm{P}^{i} \mathrm{Pr}_{2}\right)_{2}\right), 34.8\left(\mathrm{~s}, C\left(\mathrm{CH}_{3}\right)_{2}\right), 34.4\left(\mathrm{~s}, \mathrm{C}\left(\mathrm{CH}_{3}\right)_{2}\right), 30.8(\mathrm{vt}, N=13.9$, $\left.\mathrm{PCH}\left(\mathrm{CH}_{3}\right)_{2}\right), 27.4$ (vt, $\left.N=29.8, \mathrm{PCH}\left(\mathrm{CH}_{3}\right)_{2}\right), 25.0\left(\mathrm{~s}, \mathrm{COCH}_{3}\right), 24.5$ (s, $\left.\mathrm{C}\left(\mathrm{CH}_{3}\right)_{2}\right), 20.7$ (vt, $\left.N=11.8, \operatorname{PCH}\left(\mathrm{CH}_{3}\right)_{2}\right), 19.9$ (s, $\left.\mathrm{PCH}\left(\mathrm{CH}_{3}\right)_{2}\right)$, $19.3\left(\mathrm{vt}, N=8.4, \operatorname{PCH}\left(\mathrm{CH}_{3}\right)_{2}\right), 18.9\left(\mathrm{~s}, \operatorname{PCH}\left(\mathrm{CH}_{3}\right)_{2}\right) .{ }^{31} \mathrm{P}\left\{{ }^{1} \mathrm{H}\right\} \mathrm{NMR}$ $\left(121.43 \mathrm{MHz}, \mathrm{C}_{6} \mathrm{D}_{6}, 298 \mathrm{~K}\right): \delta 71.5$ (s).

Reaction of $\mathrm{OsH}_{4}\left\{\operatorname{xant}\left(\mathrm{P}^{i} \operatorname{Pr}_{2}\right)_{2}\right\}$ (1) with Benzylideneacetophenone: Preparation of OsH $\left\{\kappa^{2}-\mathrm{C}, \mathrm{O}\right.$ $\left.\left[\mathrm{C}_{6} \mathrm{H}_{4} \mathrm{C}(\mathrm{CH}=\mathrm{CHPh}) \mathrm{O}\right]\right\}\left\{\operatorname{xant}\left(\mathrm{P}^{i} \mathrm{Pr}_{2}\right)_{2}\right\} \quad(14)$ and $\mathrm{OsH}\left\{\kappa^{2}-\mathrm{C}, \mathrm{O}-\right.$ $[\mathbf{C}(\mathbf{P h}) \mathbf{C H C}(\mathbf{P h}) \mathbf{O}]\}\left\{\operatorname{xant}\left(\mathbf{P}^{i} \mathbf{P r}_{2}\right)_{2}\right\} \quad$ (15). These complexes were prepared analogously as described for 2 starting from $\mathbf{1}$ (75 mg, 0.118 mmol) and benzylideneacetophenone $(25 \mathrm{mg}, 0.118 \mathrm{mmol})$. Dark red solid. ${ }^{1} \mathrm{H}$ and ${ }^{31} \mathrm{P}\left\{{ }^{1} \mathrm{H}\right\}$ NMR spectroscopies show a 2:1 mixture of complexes 14 and 15 . Yield: $63 \mathrm{mg}(64 \%)$. Anal. Calcd. for $\mathrm{C}_{42} \mathrm{H}_{52} \mathrm{O}_{2} \mathrm{OsP}_{2}$ : C, 59.98; H, 6.23. Found: C, 59.65; H, 5.82. HRMS (electrospray, $m / z$ ): calcd. for $\mathrm{C}_{42} \mathrm{H}_{51} \mathrm{O}_{2} \mathrm{OsP}_{2}[\mathrm{M}-\mathrm{H}]^{+}$: 841.2976, found: 841.3110. IR ( $\left.\mathrm{cm}^{-1}\right)$ : v(Os-H) 2047 (w).

Spectroscopic data for OsH $\left\{\kappa^{2}-\mathrm{C}, \mathrm{O}-\right.$ $\left.\left[\mathrm{C}_{6} \mathrm{H}_{4} \mathrm{C}(\mathrm{CH}=\mathrm{CHPh}) \mathrm{O}\right]\right\}\left\{\operatorname{xant}\left(\mathrm{P}^{i} \mathrm{Pr}_{2}\right)_{2}\right\} \quad(\mathbf{1 4}):{ }^{1} \mathrm{H} \quad \mathrm{NMR} \quad(300 \mathrm{MHz}$, $\left.\mathrm{C}_{6} \mathrm{D}_{6}, 298 \mathrm{~K}\right): \delta 8.46\left(\mathrm{~d}, J_{\mathrm{H}-\mathrm{H}}=8.0,1 \mathrm{H}, \mathrm{CH}=\mathrm{CHPh}\right), 8.39\left(\mathrm{~d}, J_{\mathrm{H}-\mathrm{H}}=\right.$ $\left.7.2,2 \mathrm{H}, \mathrm{CH}_{\text {arom }}\right), 7.79\left(\mathrm{~m}, 1 \mathrm{H}, \mathrm{CH}_{\text {arom }}\right), 7.38-6.65\left(13 \mathrm{H}, \mathrm{CH}_{\text {arom }}\right.$, $\mathrm{CH}=\mathrm{CHPh}$ and $\left.\mathrm{CH}_{\text {arom }}-\mathrm{xant}\left(\mathrm{P}^{i} \mathrm{Pr}_{2}\right)_{2}\right), 2.41\left(\mathrm{~m}, 2 \mathrm{H}, \mathrm{PCH}\left(\mathrm{CH}_{3}\right)_{2}\right), 2.21$ $\left(\mathrm{m}, 2 \mathrm{H}, \mathrm{PCH}\left(\mathrm{CH}_{3}\right)_{2}\right), 1.39\left(\mathrm{~s}, 3 \mathrm{H}, \mathrm{CH}_{3}\right), 1.30\left(\mathrm{dvt}, 6 \mathrm{H}, J_{\mathrm{H}-\mathrm{H}}=5.0\right.$, $\left.N=16.5, \mathrm{PCH}\left(\mathrm{CH}_{3}\right)_{2}\right), 1.15$ (dvt, overlapped, $\left.6 \mathrm{H}, \mathrm{PCH}\left(\mathrm{CH}_{3}\right)_{2}\right), 1.12$ $\left(\mathrm{s}, 3 \mathrm{H}, \mathrm{CH}_{3}\right), 1.04\left(\mathrm{dvt}, 6 \mathrm{H}, J_{\mathrm{H}-\mathrm{H}}=6.0, \mathrm{~N}=15.0, \mathrm{PCH}\left(\mathrm{CH}_{3}\right)_{2}\right), 0.86$ (dvt, overlapped, $\left.6 \mathrm{H}, \mathrm{PCH}\left(\mathrm{CH}_{3}\right)_{2}\right),-18.09$ (t, $\left.J_{\mathrm{H}-\mathrm{P}}=23.0,1 \mathrm{H}, \mathrm{OsH}\right)$. ${ }^{13} \mathrm{C}\left\{{ }^{1} \mathrm{H}\right\}$ NMR $\left(75 \mathrm{MHz}, \mathrm{C}_{6} \mathrm{D}_{6}, 298 \mathrm{~K}\right): \delta 189.6\left(\mathrm{t}, J_{\mathrm{C}-\mathrm{P}}=1.6, \mathrm{CO}\right)$, $185.4\left(\mathrm{t}, J_{\mathrm{C}-\mathrm{P}}=4.3\right.$, OsC), $159.5\left(\mathrm{vt}, N=13.4, \mathrm{C}_{\text {arom }}-\mathrm{Xant}\left(\mathrm{P}^{i} \mathrm{Pr}_{2}\right)_{2}\right)$, $149.8(\mathrm{~s}, C \mathrm{H}=\mathrm{CHPh}), 142.6(\mathrm{~s}, C \mathrm{CO}), 141.3\left(\mathrm{~s}, \mathrm{C}_{\text {arom }}\right), 132.6(\mathrm{vt}, N=$ 5.1, $\left.\mathrm{C}_{\text {arom }}-\mathrm{xant}\left(\mathrm{P}^{i} \mathrm{Pr}_{2}\right)_{2}\right), \quad 131.2 \quad\left(\mathrm{~s}, \quad \mathrm{CH}_{\text {arom }}\right), 130.3 \quad\left(\mathrm{~s}, \quad \mathrm{CH}_{\text {arom }}{ }^{-}\right.$ $\left.\operatorname{xant}\left(\mathrm{P}^{i} \mathrm{Pr}_{2}\right)_{2}\right), 129.7,129.5,128.7,128.6$ (all s, $\left.\mathrm{CH}_{\text {arom}}\right), 128.1,127.8$ (these resonances are masked by the resonance of $\mathrm{C}_{6} \mathrm{D}_{6}, \mathrm{C}_{i p s o^{-}}$ $\operatorname{xant}\left(\mathrm{P}^{i} \mathrm{Pr}_{2}\right)_{2}$ and $\left.\mathrm{CH}_{\text {arom }}\right), 127.6\left(\mathrm{~s}, \mathrm{CH}_{\text {arom }}\right), 126.7$ (s, $\mathrm{CH}_{\text {arom }}{ }^{-}$ xant $\left.\left(\mathrm{P}^{i} \mathrm{Pr}_{2}\right)_{2}\right), 124.8\left(\mathrm{vt}, N=4.2, \mathrm{CH}_{\text {arom }}-\mathrm{Xant}\left(\mathrm{P}^{i} \mathrm{Pr}_{2}\right)_{2}\right), 114.3(\mathrm{~s}$, $\mathrm{CH}=\mathrm{CHPh}), 34.7\left(\mathrm{~s}, \mathrm{C}\left(\mathrm{CH}_{3}\right)_{2}\right), 34.6\left(\mathrm{~s}, C\left(\mathrm{CH}_{3}\right)_{2}\right), 29.6(\mathrm{vt}, \mathrm{N}=18.0$, $\left.\mathrm{PCH}\left(\mathrm{CH}_{3}\right)_{2}\right), 29.1$ (vt, $\left.N=33.1, \mathrm{PCH}\left(\mathrm{CH}_{3}\right)_{2}\right), 25.6\left(\mathrm{~s}, \mathrm{C}\left(\mathrm{CH}_{3}\right)_{2}\right), 20.1$ (s, $\left.\mathrm{PCH}\left(\mathrm{CH}_{3}\right)_{2}\right), 18.9$ (vt, $\left.\mathrm{N}=7.5, \operatorname{PCH}\left(\mathrm{CH}_{3}\right)_{2}\right), 18.7\left(\mathrm{~s}, \mathrm{PCH}\left(\mathrm{CH}_{3}\right)_{2}\right)$, $18.2\left(\mathrm{vt}, N=7.3, \mathrm{PCH}\left(\mathrm{CH}_{3}\right)_{2}\right) .{ }^{31} \mathrm{P}\left\{{ }^{1} \mathrm{H}\right\}$ NMR $\left(121.43 \mathrm{MHz}, \mathrm{C}_{6} \mathrm{D}_{6}\right.$, $298 \mathrm{~K}): \delta 47.0(\mathrm{~s})$.

Spectroscopic data for $\mathrm{OsH}\left\{\kappa^{2}-\mathrm{C}, \mathrm{O}-\right.$ $[\mathrm{C}(\mathrm{Ph}) \mathrm{CHC}(\mathrm{Ph}) \mathrm{O}]\}\left\{\operatorname{xant}\left(\mathrm{P}^{i} \mathrm{Pr}_{2}\right)_{2}\right\} \quad(\mathbf{1 5}):{ }^{1} \mathrm{H}$ NMR $\left(300 \mathrm{MHz}, \mathrm{C}_{6} \mathrm{D}_{6}\right.$, $298 \mathrm{~K}): \delta 8.67\left(\mathrm{~d}, J_{\mathrm{H}-\mathrm{H}}=7.5,2 \mathrm{H}, \mathrm{CH}_{\text {arom }}\right), 7.76\left(\mathrm{~m}, 1 \mathrm{H}, \mathrm{CH}_{\text {arom }}\right), 7.99$ (s, OsCCH), 7.38-6.65 (m, 13H, $\mathrm{CH}_{\text {arom }}$ and $\left.\mathrm{CH}_{\text {arom }}-\mathrm{xant}\left(\mathrm{P}^{i} \mathrm{Pr}_{2}\right)_{2}\right), 2.43$ $\left(\mathrm{m}, 2 \mathrm{H}, \mathrm{PCH}\left(\mathrm{CH}_{3}\right)_{2}\right), 2.36\left(\mathrm{~m}, 2 \mathrm{H}, \mathrm{PCH}\left(\mathrm{CH}_{3}\right)_{2}\right), 1.36\left(\mathrm{~s}, 3 \mathrm{H}, \mathrm{CH}_{3}\right)$, 
1.19 (dvt, overlapped, 6H, $\left.\mathrm{PCH}\left(\mathrm{CH}_{3}\right)_{2}\right), 1.13$ (s, 3H, $\left.\mathrm{CH}_{3}\right), 0.93$ (dvt, $\left.6 \mathrm{H}, J_{\mathrm{H}-\mathrm{H}}=7.5, N=13.5, \mathrm{PCH}\left(\mathrm{CH}_{3}\right)_{2}\right), 0.86$ (dvt, overlapped, $6 \mathrm{H}$, $\left.\mathrm{PCH}\left(\mathrm{CH}_{3}\right)_{2}\right), 0.74\left(\mathrm{dvt}, J_{\mathrm{H}-\mathrm{H}}=7.5, N=16.5,6 \mathrm{H}, \mathrm{PCH}\left(\mathrm{CH}_{3}\right)_{2}\right),-16.37$ $\left(\mathrm{t}, J_{\mathrm{H}-\mathrm{P}}=23.7,1 \mathrm{H}, \mathrm{OsH}\right) .{ }^{13} \mathrm{C}\left\{{ }^{1} \mathrm{H}\right\} \mathrm{NMR}\left(75 \mathrm{MHz}, \mathrm{C}_{6} \mathrm{D}_{6}, 298 \mathrm{~K}\right): \delta$ $223.3\left(\mathrm{t}, J_{\mathrm{C}-\mathrm{P}}=2.8, \mathrm{OsC}\right), 208.8\left(\mathrm{t}, J_{\mathrm{C}-\mathrm{P}}=1.6, \mathrm{CO}\right), 158.3(\mathrm{vt}, N=$ 13.1, $\left.\mathrm{C}_{\text {arom-xant }}\left(\mathrm{P}^{i} \mathrm{Pr}_{2}\right)_{2}\right), 157.5,140.3$ (both s, $\left.\mathrm{C}_{i p s o} \mathrm{Ph}\right), 132.2$ (vt, $N=$ 5.2, $\left.\mathrm{C}_{\text {arom }}-\mathrm{xant}\left(\mathrm{P}^{i} \mathrm{Pr}_{2}\right)_{2}\right), 132.5,130.6$ (both $\left.\mathrm{s}, \mathrm{CH}_{\text {arom }} \mathrm{xant}\left(\mathrm{P}^{i} \mathrm{Pr}_{2}\right)_{2}\right)$, $129.0,128.8,128.7,128.4$ (all s, $\mathrm{CH}_{\text {arom }}$ ), 127.7 (this resonance is masked by the resonance of $\mathrm{C}_{6} \mathrm{D}_{6}, \mathrm{C}_{i p s o}$-xant $\left.\left(\mathrm{P}^{i} \mathrm{Pr}_{2}\right)_{2}\right), 127.4,126.1$, 125.6 (all s, $\left.\mathrm{CH}_{\text {arom }}\right), 122.5(\mathrm{~s}, \mathrm{COCH}), 34.8\left(\mathrm{~s}, \mathrm{C}\left(\mathrm{CH}_{3}\right)_{2}\right), 30.4$ (s, $\left.C\left(\mathrm{CH}_{3}\right)_{2}\right), 29.2$ (vt, $\left.N=19.1, \mathrm{PCH}\left(\mathrm{CH}_{3}\right)_{2}\right), 28.6(\mathrm{vt}, N=33.8$, $\left.\mathrm{PCH}\left(\mathrm{CH}_{3}\right)_{2}\right), 27.2\left(\mathrm{~s}, \mathrm{C}\left(\mathrm{CH}_{3}\right)_{2}\right), 19.9$ (vt, $\left.N=6.7, \mathrm{PCH}\left(\mathrm{CH}_{3}\right)_{2}\right), 18.9$, 18.6, 18.0 (all s, $\left.\mathrm{PCH}\left(\mathrm{CH}_{3}\right)_{2}\right) .{ }^{31} \mathrm{P}\left\{{ }^{1} \mathrm{H}\right\}$ NMR $\left(121.43 \mathrm{MHz}, \mathrm{C}_{6} \mathrm{D}_{6}, 298\right.$ $\mathrm{K}): \delta 47.5$ (s).

Reaction of $\operatorname{RuH}\left(\eta^{2}-\mathrm{H}_{2} \mathrm{BH}_{2}\right)\left\{\operatorname{xant}\left(\mathrm{P}^{i} \mathrm{Pr}_{2}\right)_{2}\right\}$ (4) with Benzylideneacetophenone: Preparation of $\mathrm{RuH}\left\{\boldsymbol{\kappa}^{2}-\mathrm{C}, \mathrm{O}-\right.$ $\left.\left[\mathrm{C}_{6} \mathrm{H}_{4} \mathrm{C}(\mathrm{CH}=\mathrm{CHPh}) \mathrm{O}\right]\right\}\left\{\operatorname{xant}\left(\mathrm{P}^{i} \mathrm{Pr}_{2}\right)_{2}\right\}$ (16) and $\operatorname{RuH}\left\{\boldsymbol{\kappa}^{2}-\mathrm{C}, \mathrm{O}-\right.$ $[\mathbf{C}(\mathbf{P h}) \mathbf{C H C}(\mathbf{P h}) \mathbf{O}\}\left\{\left\{\operatorname{xant}\left(\mathbf{P}^{i} \mathbf{P r}_{2}\right)_{2}\right\}\right.$ (17). This complex was prepared analogously as described for 5 starting from 4 (75 mg, $0.134 \mathrm{mmol})$, benzylideneacetophenone $(56 \mathrm{mg}, 0.268 \mathrm{mmol})$ and 2-propanol (10 $\mu \mathrm{L}, 0.134 \mathrm{mmol})$. Dark green solid. ${ }^{1} \mathrm{H}$ and ${ }^{31} \mathrm{P}\left\{{ }^{1} \mathrm{H}\right\}$ NMR spectroscopies show a 1:1 mixture of complexes $\mathbf{1 6}$ and $\mathbf{1 7}$. Yield: $88 \mathrm{mg}$ $(90 \%)$. ${ }^{1} \mathrm{H}$ NMR spectra of the crude reaction mixture showed the presence of 1,3-diphenyl-1-propanone. Anal. Calcd. for $\mathrm{C}_{42} \mathrm{H}_{52} \mathrm{O}_{2} \mathrm{P}_{2} \mathrm{Ru}: \mathrm{C}, 67.09 ; \mathrm{H}, 6.97$. Found: $\mathrm{C}, 66.75 ; \mathrm{H}, 6.72$. HRMS (electrospray, $m / z$ ): calcd. for $\mathrm{C}_{42} \mathrm{H}_{52} \mathrm{O}_{2} \mathrm{P}_{2} \mathrm{Ru}[\mathrm{M}-\mathrm{H}]^{+}$: 751.2414, found: 751.2393. IR $\left(\mathrm{cm}^{-1}\right): v(\mathrm{Ru}-\mathrm{H}) 2054,1950(\mathrm{w})$.

Spectroscopic data for $\operatorname{RuH}\left\{\kappa^{2}-\mathrm{C}, \mathrm{O}-\right.$ $\left.\left[\mathrm{C}_{6} \mathrm{H}_{4} \mathrm{C}(\mathrm{CH}=\mathrm{CHPh}) \mathrm{O}\right]\right\}\left\{\operatorname{xant}\left(\mathrm{P}^{i} \mathrm{Pr}_{2}\right)_{2}\right\} \quad$ (16): ${ }^{1} \mathrm{H}$ NMR $(300 \mathrm{MHz}$, $\left.\mathrm{C}_{6} \mathrm{D}_{6}, 298 \mathrm{~K}\right): \delta 8.46\left(\mathrm{~d}, J_{\mathrm{H}-\mathrm{H}}=6.0,1 \mathrm{H}, \mathrm{CH}=\mathrm{CHPh}\right), 8.38\left(\mathrm{~d}, J_{\mathrm{H}-\mathrm{H}}=\right.$ 6.0, 2H, CH $\mathrm{CH}_{\text {arom }}$-xant $\left.\left(\mathrm{P}^{i} \mathrm{Pr}_{2}\right)_{2}\right), 7.74\left(\mathrm{~m}, 1 \mathrm{H}, \mathrm{CH}_{\text {arom }}\right), 7.28-6.84(\mathrm{~m}$, $\left.12 \mathrm{H}, \mathrm{CH}_{\text {arom }}\right), 6.73\left(\mathrm{t}, J_{\mathrm{H}-\mathrm{H}}=6.0,1 \mathrm{H}, \mathrm{CH}_{\text {arom }}\right), 2.42(\mathrm{~m}, 2 \mathrm{H}$, $\left.\mathrm{PCH}\left(\mathrm{CH}_{3}\right)_{2}\right), 2.24\left(\mathrm{~m}, 2 \mathrm{H}, \mathrm{PCH}\left(\mathrm{CH}_{3}\right)_{2}\right), 1.33\left(\mathrm{~s}, 3 \mathrm{H}, \mathrm{CH}_{3}\right), 1.32$ (dvt, $\left.6 \mathrm{H}, J_{\mathrm{H}-\mathrm{H}}=6.0, N=14.5, \mathrm{PCH}\left(\mathrm{CH}_{3}\right)_{2}\right), 1.24\left(\mathrm{dvt}, 6 \mathrm{H}, J_{\mathrm{H}-\mathrm{H}}=6.0\right.$, $\left.N=15.0, \quad \mathrm{PCH}\left(\mathrm{CH}_{3}\right)_{2}\right), 1.11\left(\mathrm{~s}, 3 \mathrm{H}, \mathrm{CH}_{3}\right), 1.07-089(\mathrm{~m}, 12 \mathrm{H}$, $\left.\mathrm{PCH}\left(\mathrm{CH}_{3}\right)_{2}\right), 0.89$ (dvt, overlapped, $\left.6 \mathrm{H}, \mathrm{PCH}\left(\mathrm{CH}_{3}\right)_{2}\right),-16.30$ (t, $J_{\mathrm{H}-\mathrm{P}}=$ 24.0, 1H, OsH). ${ }^{13} \mathrm{C}\left\{{ }^{1} \mathrm{H}\right\}$ NMR $\left(75 \mathrm{MHz}, \mathrm{C}_{6} \mathrm{D}_{6}, 298 \mathrm{~K}\right): \delta 209.9\left(\mathrm{t}, J_{\mathrm{C}-}\right.$ $\mathrm{p}=9.1, \mathrm{RuC}), 186.9\left(\mathrm{t}, J_{\mathrm{C}-\mathrm{P}}=2.3, \mathrm{CO}\right), 156.9\left(\mathrm{vt}, N=15.1, \mathrm{C}_{\text {arom }}{ }^{-}\right.$ xant $\left.\left(\mathrm{P}^{i} \mathrm{Pr}_{2}\right)_{2}\right), 147.7(\mathrm{~s}, \mathrm{CH}=\mathrm{CHPh}), 142.5(\mathrm{~s}, C \mathrm{CO}), 140.6$ (s, $\left.\mathrm{C}_{\text {arom }}\right)$, 132.2 (vt, $N=5.3, \mathrm{C}_{\text {arom }}$-xant $\left.\left(\mathrm{P}^{i} \mathrm{Pr}_{2}\right)_{2}\right), 130.8\left(\mathrm{~s}, \mathrm{CH}_{\text {arom }}-\mathrm{xant}\left(\mathrm{P}^{i} \mathrm{Pr}_{2}\right)_{2}\right)$, $129.5,129.1,128.8,128.7$ (all s, $\mathrm{CH}_{\text {arom }}$ ), 128.3 (this resonance is masked by the resonance of $\left.\mathrm{C}_{6} \mathrm{D}_{6}, \mathrm{C}_{i p s o}-\operatorname{xant}\left(\mathrm{P}^{i} \mathrm{Pr}_{2}\right)_{2}\right), 127.5$ (s, $\mathrm{CH}_{\text {arom }}$ ), 126.3 (s, $\mathrm{CH}_{\text {arom }}$-Xant $\left.\left(\mathrm{P}^{i} \mathrm{Pr}_{2}\right)_{2}\right), 124.3$ (vt, $\mathrm{N}=4.5, \mathrm{CH}_{\text {arom- }}{ }^{-}$ $\left.\operatorname{xant}\left(\mathrm{P}^{i} \mathrm{Pr}_{2}\right)_{2}\right), 115.7(\mathrm{~s}, \mathrm{CH}=\mathrm{CHPh}), 34.8\left(\mathrm{~s}, \mathrm{C}\left(\mathrm{CH}_{3}\right)_{2}\right), 34.5(\mathrm{~s}$, $\left.\mathrm{C}\left(\mathrm{CH}_{3}\right)_{2}\right), 28.6$ (vt, $\left.N=27.9, \mathrm{PCH}\left(\mathrm{CH}_{3}\right)_{2}\right), 28.1$ (vt, $N=14.3$, $\left.\mathrm{PCH}\left(\mathrm{CH}_{3}\right)_{2}\right), 27.5\left(\mathrm{~s}, \mathrm{C}\left(\mathrm{CH}_{3}\right)_{2}\right), 20.1\left(\mathrm{~s}, \mathrm{PCH}\left(\mathrm{CH}_{3}\right)_{2}\right), 19.9$ (vt, $N=$ 7.6, $\left.\mathrm{PCH}\left(\mathrm{CH}_{3}\right)_{2}\right), 18.8$ and 18.1 (both s, $\left.\mathrm{PCH}\left(\mathrm{CH}_{3}\right)_{2}\right) .{ }^{31} \mathrm{P}\left\{{ }^{1} \mathrm{H}\right\} \mathrm{NMR}$ $\left(121.43 \mathrm{MHz}, \mathrm{C}_{6} \mathrm{D}_{6}, 298 \mathrm{~K}\right): \delta 62.4(\mathrm{~s})$.

Spectroscopic data for $\operatorname{RuH}\left\{\kappa^{2}-\mathrm{C}, \mathrm{O}-\right.$ $[\mathrm{C}(\mathrm{Ph}) \mathrm{CHC}(\mathrm{Ph}) \mathrm{O}]\}\left\{\operatorname{xant}\left(\mathrm{P}^{i} \mathrm{Pr}_{2}\right)_{2}\right\} \quad(\mathbf{1 7}):{ }^{1} \mathrm{H}$ NMR $\left(300 \mathrm{MHz}, \mathrm{C}_{6} \mathrm{D}_{6}\right.$, $298 \mathrm{~K}): \delta 8.62\left(\mathrm{~d}, J_{\mathrm{H}-\mathrm{H}}=6.0,2 \mathrm{H}, \mathrm{CH}_{\mathrm{arom}}\right), 8.09(\mathrm{~s}, 1 \mathrm{H}, \mathrm{COCH}), 7.72$ $\left(\mathrm{m}, 1 \mathrm{H}, \mathrm{CH}_{\text {arom }}\right), 7.39\left(\mathrm{t}, J_{\mathrm{H}-\mathrm{H}}=6.0,2 \mathrm{H}, \mathrm{CH}_{\text {arom }}\right.$-Xant $\left.\left(\mathrm{P}^{i} \mathrm{Pr}_{2}\right)_{2}\right), 7.28-$ $6.84\left(\mathrm{~m}, 11 \mathrm{H}, \mathrm{CH}_{\text {arom }}\right.$ and $\mathrm{CH}_{\text {arom }}$-xant $\left.\left(\mathrm{P}^{i} \mathrm{Pr}_{2}\right)_{2}\right), 2.30(\mathrm{~m}, 2 \mathrm{H}$, $\left.\mathrm{PCH}\left(\mathrm{CH}_{3}\right)_{2}\right), 2.07\left(\mathrm{~m}, 2 \mathrm{H}, \mathrm{PCH}\left(\mathrm{CH}_{3}\right)_{2}\right), 1.36\left(\mathrm{~s}, 3 \mathrm{H}, \mathrm{CH}_{3}\right), 1.14$ (dvt, $\left.6 \mathrm{H}, J_{\mathrm{H}-\mathrm{H}}=6.9, N=13.5, \mathrm{PCH}\left(\mathrm{CH}_{3}\right)_{2}\right), 1.13\left(\mathrm{~s}, 3 \mathrm{H}, \mathrm{CH}_{3}\right), 0.99-0.87(2$ dvts, overlapped, $\left.12 \mathrm{H}, \quad \mathrm{PCH}\left(\mathrm{CH}_{3}\right)_{2}\right), 0.78 \quad\left(\mathrm{dvt}, 6 \mathrm{H}, \quad J_{\mathrm{H}-\mathrm{H}}=6.9\right.$, $N=15.3, \quad$ PCH $\left.\left(\mathrm{CH}_{3}\right)_{2}\right), \quad-14.46 \quad\left(\mathrm{t}, \quad J_{\mathrm{H}-\mathrm{P}}=26.1, \quad 1 \mathrm{H}, \quad \mathrm{OsH}\right)$. ${ }^{13} \mathrm{C}\left\{{ }^{1} \mathrm{H}\right\}$ NMR $\left(75 \mathrm{MHz}, \mathrm{C}_{6} \mathrm{D}_{6}, 298 \mathrm{~K}\right): \delta 255.0\left(\mathrm{t}, J_{\mathrm{C}-\mathrm{P}}=6.7, \mathrm{OsC}\right)$, $203.2\left(\mathrm{t}, J_{\mathrm{C}-\mathrm{P}}=1.8, \mathrm{CO}\right), 158.2\left(\mathrm{vt}, N=15.2, \mathrm{C}_{\text {arom }}-\mathrm{xant}\left(\mathrm{P}^{i} \mathrm{Pr}_{2}\right)_{2}\right)$, $154.0\left(\mathrm{~s}, \mathrm{C}_{i p s o} \mathrm{Ph}\right), 137.5\left(\mathrm{~s}, \mathrm{C}_{\text {ipso }} \mathrm{Ph}\right), 132.8\left(\mathrm{vt}, N=5.4, \mathrm{C}_{\text {arom- }}{ }^{-}\right.$ $\left.\operatorname{xant}\left(\mathrm{P}^{i} \mathrm{Pr}_{2}\right)_{2}\right), 132.7,130.1$ (both s, $\left.\mathrm{CH}_{\text {arom }}-\mathrm{xant}\left(\mathrm{P}^{i} \mathrm{Pr}_{2}\right)_{2}\right), 128.7,128.6$, 128.5 (all s, $\mathrm{CH}_{\text {arom }}$ ), 128.3, 128.1 (these resonances are masked by the resonance of $\mathrm{C}_{6} \mathrm{D}_{6}, \mathrm{CH}_{\text {arom }}$ and $\left.\mathrm{C}_{i p s o}-\operatorname{xant}\left(\mathrm{P}^{i} \mathrm{Pr}_{2}\right)_{2}\right), 127.5,126.6$ (both s, $\left.\mathrm{CH}_{\text {arom }}\right), 120.5$ (s, $\left.\mathrm{COCH}\right), 34.6,30.5$ (both s, $\left.\mathrm{C}\left(\mathrm{CH}_{3}\right)_{2}\right), 30.4$ (s, $\left.C\left(\mathrm{CH}_{3}\right)_{2}\right), 28.9$ (vt, $\left.N=12.2, \mathrm{PCH}\left(\mathrm{CH}_{3}\right)_{2}\right), 27.9$ (vt, $N=27.3$, $\left.\mathrm{PCH}\left(\mathrm{CH}_{3}\right)_{2}\right), 19.2$ (vt, $\left.N=8.9, \operatorname{PCH}\left(\mathrm{CH}_{3}\right)_{2}\right), 18.8$ and 18.7 (both s, $\left.\operatorname{PCH}\left(\mathrm{CH}_{3}\right)_{2}\right), 18.5\left(\mathrm{vt}, N=8.6, \operatorname{PCH}\left(\mathrm{CH}_{3}\right)_{2}\right) .{ }^{31} \mathrm{P}\left\{{ }^{1} \mathrm{H}\right\}$ NMR $(121.43$ $\left.\mathrm{MHz}, \mathrm{C}_{6} \mathrm{D}_{6}, 298 \mathrm{~K}\right): \delta 64.1(\mathrm{~s})$.

Reaction of $\mathrm{OsH}_{4}\left\{\operatorname{xant}\left(\mathrm{P}^{i} \mathrm{Pr}_{2}\right)_{2}\right\}$ (1) with Benzaldehyde: Preparation of $\mathbf{O s H}(\mathbf{P h})(\mathbf{C O})\left\{\operatorname{xant}\left(\mathbf{P}^{i} \mathbf{P r}_{2}\right)_{2}\right\}$ (18). A solution of $\mathbf{1}(125 \mathrm{mg}$,
$0.196 \mathrm{mmol})$ in toluene $(12 \mathrm{~mL})$ was treated with benzaldehyde ( 24 $\mu \mathrm{L}, 0.235 \mathrm{mmol}$ ) and the resulting mixture was heated to reflux for 15 h. After being cooled at room temperature, the solution was evaporated to afford a white residue. Addition of methanol $(2 \mathrm{~mL})$ afforded a white solid that was washed with methanol $(2 \times 2 \mathrm{~mL})$ and dried in vacuo. Yield: $106 \mathrm{mg}$ (71\%). Anal. Calcd. for $\mathrm{C}_{34} \mathrm{H}_{46} \mathrm{O}_{2} \mathrm{OsP}_{2}$ : C, 55.27; H, 6.27. Found: C, 54.95; H, 6.42. HRMS (electrospray, $\mathrm{m} / \mathrm{z}$ ): calcd. for $\mathrm{C}_{34} \mathrm{H}_{45} \mathrm{O}_{2} \mathrm{OsP}_{2}[\mathrm{M}-\mathrm{H}]^{+}$: 739.2506, found: 739.2493. IR $\left(\mathrm{cm}^{-1}\right): v(\mathrm{C} \equiv \mathrm{O}) 1871(\mathrm{~s}) .{ }^{\mathrm{I}} \mathrm{H}$ NMR $\left(300 \mathrm{MHz}, \mathrm{C}_{7} \mathrm{D}_{8}, 253 \mathrm{~K}\right): \delta 8.75$ $\left(\mathrm{d}, J_{\mathrm{H}-\mathrm{H}}=7.2,1 \mathrm{H}, \mathrm{CH}_{\text {arom }}\right), 7.34\left(\mathrm{~d}, J_{\mathrm{H}-\mathrm{H}}=7.2,1 \mathrm{H}, \mathrm{CH}_{\text {arom }}\right), 7.12-6.78$ (m, 9H, CHarom and $\left.\mathrm{CH}_{\text {arom }}-\mathrm{xant}\left(\mathrm{P}^{i} \mathrm{Pr}_{2}\right)_{2}\right), 2.29\left(\mathrm{~m}, 2 \mathrm{H}, \mathrm{PC} H\left(\mathrm{CH}_{3}\right)_{2}\right)$, $2.04\left(\mathrm{~m}, 2 \mathrm{H}, \mathrm{PCH}\left(\mathrm{CH}_{3}\right)_{2}\right), 1.51$ (dvt, $J_{\mathrm{H}-\mathrm{H}}=7.1, N=15.6,6 \mathrm{H}$, $\left.\mathrm{PCH}\left(\mathrm{CH}_{3}\right)_{2}\right), 1.43\left(\mathrm{dvt}, J_{\mathrm{H}-\mathrm{H}}=7.2, N=15.3,6 \mathrm{H}, \mathrm{PCH}\left(\mathrm{CH}_{3}\right)_{2}\right), 1.33$ (s, $\left.3 \mathrm{H}, \mathrm{CH} \mathrm{H}_{3}\right), 1.26(\mathrm{~s}, 3 \mathrm{H}, \mathrm{CH})_{3}, 0.97\left(\mathrm{dvt}, J_{\mathrm{H}-\mathrm{H}}=7.0, N=14.9,6 \mathrm{H}\right.$, $\left.\mathrm{PCH}\left(\mathrm{CH}_{3}\right)_{2}\right), 0.58\left(\mathrm{dvt}, J_{\mathrm{H}-\mathrm{H}}=7.1, N=14.9,6 \mathrm{H}, \mathrm{PCH}\left(\mathrm{CH}_{3}\right)_{2}\right),-6.96$ $\left(\mathrm{t}, J_{\mathrm{H}-\mathrm{P}}=21.3,1 \mathrm{H}, \mathrm{OsH}\right) \cdot{ }^{13} \mathrm{C}\left\{{ }^{1} \mathrm{H}\right\}$ NMR $\left(75 \mathrm{MHz}, \mathrm{C}_{7} \mathrm{D}_{8}, 253 \mathrm{~K}\right): \delta$ $186.9\left(\mathrm{t}, J_{\mathrm{C}-\mathrm{P}}=7.6, \mathrm{CO}\right), 156.3\left(\mathrm{vt}, N=14.4, \mathrm{C}_{\text {arom }}-\mathrm{xant}\left(\mathrm{P}^{i} \mathrm{Pr}_{2}\right)_{2}\right)$, $156.2\left(\mathrm{t}, J_{\mathrm{C}-\mathrm{P}}=8.0, \mathrm{OsC}\right), 145.7,134.4$ (both $\left.\mathrm{s}, \mathrm{CH}_{\text {arom }}\right), 131.2(\mathrm{~s}$, $\left.\mathrm{C}_{\text {arom-Xant }}\left(\mathrm{P}^{i} \mathrm{Pr}_{2}\right)_{2}\right), 131.1,128.0$ (both s, $\mathrm{CH}_{\text {arom }}$-Xant $\left.\left(\mathrm{P}^{i} \mathrm{Pr}_{2}\right)_{2}\right), 127.5$ (s, $\left.\mathrm{CH}_{\text {arom }}\right), 127.0$ (vt, $\left.N=28.8, C_{\text {ipso }}-\operatorname{xant}\left(\mathrm{P}^{i} \mathrm{Pr}_{2}\right)_{2}\right), 125.7\left(\mathrm{~s}, \mathrm{CH}_{\text {arom }}\right)$, 125.3 (vt, $\left.N=4.5, \mathrm{CH}_{\text {arom }}-\mathrm{xant}\left(\mathrm{P}^{i} \mathrm{Pr}_{2}\right)_{2}\right), 120.1\left(\mathrm{~s}, \mathrm{CH}_{\text {arom }}\right), 36.7$ (s, $\left.\mathrm{C}\left(\mathrm{CH}_{3}\right)_{2}\right), 33.7\left(\mathrm{~s}, \mathrm{C}\left(\mathrm{CH}_{3}\right)_{2}\right), 32.1$ (vt, $\left.N=26.0, \mathrm{PCH}\left(\mathrm{CH}_{3}\right)_{2}\right), 30.8$ (vt, $\left.N=35.6, \quad \mathrm{PCH}\left(\mathrm{CH}_{3}\right)_{2}\right), 28.0\left(\mathrm{~s}, \mathrm{C}\left(\mathrm{CH}_{3}\right)_{2}\right), 21.1(\mathrm{vt}, N=8.0$, $\left.\operatorname{PCH}\left(\mathrm{CH}_{3}\right)_{2}\right), 20.0,19.6$ (both s, $\left.\mathrm{PCH}\left(\mathrm{CH}_{3}\right)_{2}\right), 19.5$ (vt, $N=6.5$, $\left.\mathrm{PCH}\left(\mathrm{CH}_{3}\right)_{2}\right) .{ }^{31} \mathrm{P}\left\{{ }^{1} \mathrm{H}\right\}$ NMR $\left(121.43 \mathrm{MHz}, \mathrm{C}_{6} \mathrm{D}_{6}, 298 \mathrm{~K}\right): \delta 53.0(\mathrm{~s})$.

Reaction of $\mathrm{RuH}\left(\eta^{2}-\mathrm{H}_{2} \mathrm{BH}_{2}\right)\left\{\operatorname{xant}\left(\mathrm{P}^{i} \mathrm{Pr}_{2}\right)_{2}\right\}$ (4) with Benzaldehyde: Preparation of $\operatorname{RuH}(\mathbf{P h})(\mathbf{C O})\left\{\operatorname{xant}\left(\mathrm{P}^{i} \mathrm{Pr}_{2}\right)_{2}\right\}$ (19). This complex was prepared analogously as described for $\mathbf{5}$ starting from $\mathbf{4}$ (120 mg, $0.214 \mathrm{mmol})$, benzaldehyde $(45 \mu \mathrm{L}, 0.430 \mathrm{mmol})$ and $2-$ propanol $(16 \mu \mathrm{L}, 0.214 \mathrm{mmol})$. Pale brown solid. Yield: $96 \mathrm{mg}$ $(69 \%) .{ }^{1} \mathrm{H}$ NMR spectra of the crude reaction mixture showed the presence of benzylic alcohol. Anal. Calcd. for $\mathrm{C}_{34} \mathrm{H}_{46} \mathrm{O}_{2} \mathrm{P}_{2} \mathrm{Ru}$ : $\mathrm{C}$, 62.85; H, 7.13. Found: C, 62.43; H, 7.02. IR $\left(\mathrm{cm}^{-1}\right): v(\mathrm{CO}) 1926(\mathrm{~s})$. ${ }^{1} \mathrm{H}$ NMR $\left(300 \mathrm{MHz}, \mathrm{C}_{7} \mathrm{D}_{8}, 298 \mathrm{~K}\right): \delta 7.18-6.87\left(\mathrm{~m}, 11 \mathrm{H}, \mathrm{CH}_{\text {arom }}\right.$ and $\mathrm{CH}_{\text {arom- }}$-xant $\left.\left(\mathrm{P}^{i} \mathrm{Pr}_{2}\right)_{2}\right), 2.76\left(\mathrm{~m}, 2 \mathrm{H}, \quad \mathrm{PCH}\left(\mathrm{CH}_{3}\right)_{2}\right), 2.21(\mathrm{~m}, 2 \mathrm{H}$, $\left.\mathrm{PCH}\left(\mathrm{CH}_{3}\right)_{2}\right), 1.65\left(\mathrm{dvt}, J_{\mathrm{H}-\mathrm{H}}=7.5, N=16.5,6 \mathrm{H}, \mathrm{PCH}\left(\mathrm{CH}_{3}\right)_{2}\right), 1.58$ $\left(\mathrm{dvt}, J_{\mathrm{H}-\mathrm{H}}=6.9, N=15.9,6 \mathrm{H}, \mathrm{PCH}\left(\mathrm{CH}_{3}\right)_{2}\right), 1.32\left(\mathrm{dvt}, J_{\mathrm{H}-\mathrm{H}}=6.9, N=\right.$ $\left.17.1,6 \mathrm{H}, \mathrm{PCH}\left(\mathrm{CH}_{3}\right)_{2}\right), 1.26\left(\mathrm{~s}, 3 \mathrm{H}, \mathrm{CH}_{3}\right), 1.10\left(\mathrm{~s}, 3 \mathrm{H}, \mathrm{CH}_{3}\right), 0.89$ $\left(\mathrm{dvt}, J_{\mathrm{H}-\mathrm{H}}=6.9, N=15.6,6 \mathrm{H}, \mathrm{PCH}\left(\mathrm{CH}_{3}\right)_{2}\right),-13.71\left(\mathrm{t}, J_{\mathrm{H}-\mathrm{P}}=19.2,1 \mathrm{H}\right.$, $\mathrm{RuH}) .{ }^{13} \mathrm{C}\left\{{ }^{1} \mathrm{H}\right\}$ NMR $\left(75 \mathrm{MHz}, \mathrm{C}_{7} \mathrm{D}_{8}, 298 \mathrm{~K}\right): \delta 208.5$ (t, $J_{\mathrm{C}-\mathrm{P}}=6.5$, $\mathrm{CO}$ ), 156.0 (t, $J_{\mathrm{C}-\mathrm{P}}=8.1, \mathrm{OsC}$ ), 155.9 (vt, $N=15.2, \mathrm{C}_{\text {arom }}{ }^{-}$ $\left.\operatorname{xant}\left(\mathrm{P}^{i} \mathrm{Pr}_{2}\right)_{2}\right), 133.7\left(\mathrm{~s}, \mathrm{CH}_{\text {arom }}\right), 132.0$ (vt, $\left.N=6.0, \mathrm{C}_{\text {arom }}-\mathrm{xant}\left(\mathrm{P}^{i} \mathrm{Pr}_{2}\right)_{2}\right)$, 131.0 and 128.7 (both s, $\left.\mathrm{CH}_{\text {arom }}-\mathrm{xant}\left(\mathrm{P}^{i} \mathrm{Pr}_{2}\right)_{2}\right), 128.3$ and 128.1 (these resonances are masked by the resonance of $\mathrm{C}_{6} \mathrm{D}_{6}, \mathrm{C}_{i p s o}$-xant $\left(\mathrm{P}^{i} \mathrm{Pr}_{2}\right)_{2}$ and $\mathrm{CH}_{\text {arom }}$ ), 124.9 (vt, $\left.N=5.2, \mathrm{CH}_{\text {arom }}-\mathrm{xant}\left(\mathrm{P}^{i} \mathrm{Pr}_{2}\right)_{2}\right), 126.4$ (s, $\left.\mathrm{CH}_{\text {arom }}\right), 35.5$ (s, $\left.\mathrm{C}\left(\mathrm{CH}_{3}\right)_{2}\right), 34.8\left(\mathrm{~s}, \mathrm{C}\left(\mathrm{CH}_{3}\right)_{2}\right), 30.0$ (vt, $N=21.6$, $\left.\mathrm{PCH}\left(\mathrm{CH}_{3}\right)_{2}\right), 28.2\left(\mathrm{vt}, \mathrm{N}=29.1, \mathrm{PCH}\left(\mathrm{CH}_{3}\right)_{2}\right), 28.1\left(\mathrm{~s}, \mathrm{C}\left(\mathrm{CH}_{3}\right)_{2}\right), 22.6$ (vt, $\left.N=3.3, \mathrm{PCH}\left(\mathrm{CH}_{3}\right)_{2}\right), 20.1,20.0$ (both s, $\left.\mathrm{PCH}\left(\mathrm{CH}_{3}\right)_{2}\right), 19.8$ (vt, $N$ $\left.=4.8, \mathrm{PCH}\left(\mathrm{CH}_{3}\right)_{2}\right) .{ }^{31} \mathrm{P}\left\{{ }^{1} \mathrm{H}\right\}$ NMR $\left(121.43 \mathrm{MHz}, \mathrm{C}_{6} \mathrm{D}_{6}, 298 \mathrm{~K}\right): \delta$ $69.5(\mathrm{~s})$.

Reaction of $\mathrm{OsH}_{4}\left\{\operatorname{xant}\left(\mathrm{P}^{i} \mathrm{Pr}_{2}\right)_{2}\right\}$ (1) with 1-Cyclohexene-1carboxaldehyde. A solution of $\mathbf{1}(100 \mathrm{mg}, 0.157 \mathrm{mmol})$ in toluene $(12 \mathrm{~mL})$ was treated with 1-cyclohexene-1-carboxaldehyde $(22 \mu \mathrm{L}$, $0.193 \mathrm{mmol}$ ) and the resulting mixture was heated to reflux for $15 \mathrm{~h}$. After being cooled at room temperature, the solution was evaporated to afford a yellow residue. Addition of methanol $(2 \mathrm{~mL})$ afforded a yellow solid that was washed with methanol $(2 \times 2 \mathrm{~mL})$ and dried in vacuo. ${ }^{1} \mathrm{H}$ and ${ }^{31} \mathrm{P}\{\mathrm{H}\}$ NMR both before and after isolation indicated a 1:1 mixture of complexes $\mathbf{2 0}$ and $\mathbf{2 1}$. GC analysis of the crude reaction mixture showed the presence of 1,3-cyclohexadiene.

Spectroscopic data for $\mathrm{OsH}\left(\mathrm{C}_{6} \mathrm{H}_{9}\right)(\mathrm{CO})\left\{\operatorname{xant}\left(\mathrm{P}^{i} \mathrm{Pr}_{2}\right)_{2}\right\}$ (20): HRMS (electrospray, $m / z$ ): calcd. for $\mathrm{C}_{34} \mathrm{H}_{50} \mathrm{O}_{2} \mathrm{OsP}_{2}[\mathrm{M}]^{+}:$: 743.2897, found: 743.2744. IR ( $\left.\mathrm{cm}^{-1}\right): v(\mathrm{CO}) 1872(\mathrm{~s}) .{ }^{1} \mathrm{H}$ NMR $\left(400 \mathrm{MHz}, \mathrm{C}_{6} \mathrm{D}_{6}, 298\right.$ $\mathrm{K}): \delta$ 7.18-6.87 (6H, $\mathrm{CH}_{\text {arom }}$-xant $\left.\left(\mathrm{P}^{i} \mathrm{Pr}_{2}\right)_{2}\right), 6.49$ (br, 1H, OsCCH), 2.68 $\left(\mathrm{m}, 4 \mathrm{H}, \mathrm{PCH}\left(\mathrm{CH}_{3}\right)_{2}\right.$ and $\left.\mathrm{CH}_{2}\right), 2.17\left(\mathrm{~m}, 2 \mathrm{H}, \mathrm{PCH}\left(\mathrm{CH}_{3}\right)_{2}\right), 1.81(\mathrm{~m}$, $\left.2 \mathrm{H}, \mathrm{CH}_{2}\right), 1.47\left(\mathrm{dvt}, J_{\mathrm{H}-\mathrm{H}}=6.9, N=14.6,6 \mathrm{H}, \mathrm{PCH}\left(\mathrm{CH}_{3}\right)_{2}\right), 1.31$ (dvt, $\left.J_{\mathrm{H}-\mathrm{H}}=7.2, N=14.1,6 \mathrm{H}, \mathrm{PCH}\left(\mathrm{CH}_{3}\right)_{2}\right), 1.29\left(\mathrm{~s}, 3 \mathrm{H}, \mathrm{CH}_{3}\right), 1.19(\mathrm{~s}, 3 \mathrm{H}$, $\mathrm{CH}_{3}$ ), 1.13 (overlapped, $\left.6 \mathrm{H}, \mathrm{PCH}\left(\mathrm{CH}_{3}\right)_{2}\right), 0.94$ (dvt, $J_{\mathrm{H}-\mathrm{H}}=6.9, N=$ $\left.14.7,6 \mathrm{H}, \mathrm{PCH}\left(\mathrm{CH}_{3}\right)_{2}\right),-7.23\left(\mathrm{t}, J_{\mathrm{H}-\mathrm{P}}=21.2,1 \mathrm{H}, \mathrm{OsH}\right)$; resonances corresponding to 4 protons of the cyclohexenyl group are overlapped in the aliphatic region. ${ }^{13} \mathrm{C}\left\{{ }^{1} \mathrm{H}\right\} \mathrm{NMR}\left(75 \mathrm{MHz}, \mathrm{C}_{6} \mathrm{D}_{6}, 253 \mathrm{~K}\right): \delta$ 
$187.3\left(\mathrm{t}, J_{\mathrm{C}-\mathrm{p}}=7.3, \mathrm{CO}\right), 157.4$ (overlapped, OsC), 157.3 (vt, $N=$ 14.3, $\mathrm{C}_{\text {arom }}$-xant $\left.\left(\mathrm{P}^{i} \mathrm{Pr}_{2}\right)_{2}\right), 134.5\left(\mathrm{t}, J_{\mathrm{C}-\mathrm{P}}=3.5, \mathrm{OsCCH}\right), 131.8\left(\mathrm{~s}, \mathrm{C}_{\text {arom }}{ }^{-}\right.$ $\left.\operatorname{xant}\left(\mathrm{P}^{i} \mathrm{Pr}_{2}\right)_{2}\right), 131.2,129.3$ (both s, $\left.\mathrm{CH}_{\text {arom }}-\operatorname{xant}\left(\mathrm{P}^{i} \mathrm{Pr}_{2}\right)_{2}\right), 128.3$ (this resonance is masked by the resonance of $\mathrm{C}_{6} \mathrm{D}_{6}, \mathrm{C}_{\mathrm{ipso}}$-xant $\left.\left(\mathrm{P}^{i} \mathrm{Pr}_{2}\right)_{2}\right)$, 125.4 (vt, $N=4.6, \mathrm{CH}_{\text {arom }}$-xant $\left.\left(\mathrm{P}^{i} \mathrm{Pr}_{2}\right)_{2}\right), 36.8\left(\mathrm{~s}, \mathrm{C}\left(\mathrm{CH}_{3}\right)_{2}\right), 34.2$ (s, $\left.C\left(\mathrm{CH}_{3}\right)_{2}\right), 31.6$ (vt, $\left.N=24.5, \mathrm{PCH}\left(\mathrm{CH}_{3}\right)_{2}\right), 31.3\left(\mathrm{~s}, \mathrm{CH}_{2}\right), 28.0$ (vt, $N=$ 18.6, $\left.\mathrm{PCH}\left(\mathrm{CH}_{3}\right)_{2}\right), 27.7\left(\mathrm{~s}, \mathrm{C}\left(\mathrm{CH}_{3}\right)_{2}\right), 27.1,24.2$ (both s, $\left.\mathrm{CH}_{2}\right), 21.5$ (br, $\left.\mathrm{PCH}\left(\mathrm{CH}_{3}\right)_{2}\right), 20.6$ (br, $\left.\mathrm{PCH}\left(\mathrm{CH}_{3}\right)_{2}\right), 20.0,19.8$ (both s, $\left.\operatorname{PCH}\left(\mathrm{CH}_{3}\right)_{2}\right) .{ }^{31} \mathrm{P}\left\{{ }^{1} \mathrm{H}\right\}$ NMR $\left(121.43 \mathrm{MHz}, \mathrm{C}_{6} \mathrm{D}_{6}, 298 \mathrm{~K}\right): \delta 52.1(\mathrm{~s}$, br).

Reaction of $\mathrm{OsH}_{4}\left\{\operatorname{xant}\left(\mathrm{P}^{i} \mathrm{Pr}_{2}\right)_{2}\right\}$ (1) with Cyclohexane Carboxaldehyde: Preparation of $\mathrm{OsH}_{2}(\mathrm{CO})\left\{\operatorname{xant}\left(\mathrm{P}^{\mathrm{i}} \mathrm{Pr}_{2}\right)_{2}\right\}$ (21). This complex was prepared analogously as described for $\mathbf{1 8}$ starting from $\mathbf{1}$ (100 $\mathrm{mg}, 0.157 \mathrm{mmol})$ and cyclohexane carboxaldehyde $(24 \mu \mathrm{L}$, $0.198 \mathrm{mmol})$. Yellow solid. Yield: $76 \mathrm{mg}(72 \%)$. GC analysis of the crude reaction mixture showed the presence of cyclohexene. Anal. Calcd. for $\mathrm{C}_{28} \mathrm{H}_{42} \mathrm{O}_{2} \mathrm{OsP}$ : C, 50.74; H, 6.39. Found: C, 50.42; H, 6.37. HRMS (electrospray, $m / z$ ): calcd. for $\mathrm{C}_{28} \mathrm{H}_{42} \mathrm{O}_{2} \mathrm{OsP}_{2}[\mathrm{M}]^{+}$: 663.2192; found 663.2167. IR $\left(\mathrm{cm}^{-1}\right): v(\mathrm{CO}): 1878(\mathrm{~s}), v(\mathrm{Os}-\mathrm{H}) 1688(\mathrm{~s}) .{ }^{1} \mathrm{H}$ NMR (300 MHz, $\left.\mathrm{C}_{6} \mathrm{D}_{6}, 298 \mathrm{~K}\right): \delta 7.16\left(\mathrm{~m}, 2 \mathrm{H}, \mathrm{CH}_{\text {arom }}\right), 6.85-6.82(\mathrm{~m}$, $\left.4 \mathrm{H}, \mathrm{CH}_{\text {arom }}\right), 2.28\left(\mathrm{~m}, 4 \mathrm{H}, \mathrm{PCH}\left(\mathrm{CH}_{3}\right)_{2}\right), 1.65\left(\mathrm{dvt}, J_{\mathrm{H}-\mathrm{H}}=6.9, N=\right.$ $\left.14.9,12 \mathrm{H}, \operatorname{PCH}\left(\mathrm{CH}_{3}\right)_{2}\right), 1.25\left(\mathrm{dvt}, J_{\mathrm{H}-\mathrm{H}}=7.0, N=15.0,12 \mathrm{H}\right.$, $\left.\mathrm{PCH}\left(\mathrm{CH}_{3}\right)_{2}\right), 1.15\left(\mathrm{~s}, 6 \mathrm{H}, \mathrm{CH}_{3}\right),-4.08\left(\mathrm{t}, J_{\mathrm{H}-\mathrm{P}}=17.7,2 \mathrm{H}, \mathrm{OsH}\right)$. ${ }^{13} \mathrm{C}\left\{{ }^{1} \mathrm{H}\right\}$ NMR $\left(75 \mathrm{MHz}, \mathrm{C}_{6} \mathrm{D}_{6}, 298 \mathrm{~K}\right): \delta 186.0\left(\mathrm{t}, J_{\mathrm{C}-\mathrm{P}}=7.8, \mathrm{CO}\right)$, 156.6 (vt, $\left.N=14.3, \mathrm{C}_{\text {arom }}-\mathrm{xant}\left(\mathrm{P}^{i} \mathrm{Pr}_{2}\right)_{2}\right), 130.5$ (vt, $N=5.5, \mathrm{C}_{\text {arom }}-$ $\left.\operatorname{xant}\left(\mathrm{P}^{i} \mathrm{Pr}_{2}\right)_{2}\right), 130.1\left(\mathrm{~s}, \mathrm{CH}_{\text {arom }}-\mathrm{xant}\left(\mathrm{P}^{i} \mathrm{Pr}_{2}\right)_{2}\right), 128.0$ (this resonance is masked by the resonance of $\left.\mathrm{C}_{6} \mathrm{D}_{6}, \mathrm{C}_{\mathrm{ipso}}-\mathrm{xant}\left(\mathrm{P}^{i} \mathrm{Pr}_{2}\right)_{2}\right), 127.7$ (s, $\mathrm{CH}_{\text {arom }}$-xant $\left.\left(\mathrm{P}^{i} \mathrm{Pr}_{2}\right)_{2}\right), 124.9$ (vt, $N=5.1, \mathrm{CH}_{\text {arom }}$-xant $\left.\left(\mathrm{P}^{\prime} \mathrm{Pr}_{2}\right)_{2}\right), 33.3$ (s, $\left.C\left(\mathrm{CH}_{3}\right)_{2}\right), 32.7\left(\mathrm{~s}, \mathrm{C}\left(\mathrm{CH}_{3}\right)_{2}\right), 30.2$ (vt, $\left.N=30.7, \mathrm{PCH}\left(\mathrm{CH}_{3}\right)_{2}\right), 20.8$ (vt, $\left.N=8.9, \operatorname{PCH}\left(\mathrm{CH}_{3}\right)_{2}\right), 19.5\left(\mathrm{~s}, \mathrm{PCH}\left(\mathrm{CH}_{3}\right)_{2}\right) .{ }^{31} \mathrm{P}\left\{{ }^{1} \mathrm{H}\right\}$ NMR $(121.43$ $\mathrm{MHz}, \mathrm{C}_{6} \mathrm{D}_{6}, 298 \mathrm{~K}$ ): $\delta 70.8$ (s, t under off-resonance conditions).

Structural Analysis of Complexes 2, 10, 13, and 21. Crystals were obtained from saturated solutions in methanol (2 and 10) or in benzene (21), or from slow diffusion of methanol into saturated solutions of $\mathbf{1 3}$ in toluene. X-ray data were collected on a Bruker Smart APEX DUO CCD diffractometer equipped with a normal focus, 2.4 $\mathrm{kW}$ sealed tube source (Mo radiation, $\lambda=0.71073 \AA$ ) operating at 50 $\mathrm{kV}$ and $40 \mathrm{~mA}(\mathbf{2}, \mathbf{1 0}, \mathbf{1 3})$ or $30 \mathrm{~mA}(\mathbf{2 1})$. Data were collected over the complete sphere. Each frame exposure time was $10 \mathrm{~s} \mathrm{(21),20 \textrm {s }}$ (2), $30 \mathrm{~s} \mathrm{(10)}$ and $60 \mathrm{~s}(\mathbf{1 3})$ covering $0.3^{\circ}$ in $\omega$. Data were corrected for absorption by using a multiscan method applied with the SADABS program. ${ }^{32}$ The structures were solved by Patterson or direct methods and refined by full-matrix least squares on $\mathrm{F}^{2}$ with SHELXL97, ${ }^{33}$ including isotropic and subsequently anisotropic displacement parameters. The hydrogen atoms (except hydrides) were observed in the least Fourier Maps or calculated, and refined freely or using a restricted riding model. Hydrogens bonded to metal atoms were observed in the last cycles of refinement but refined too close to metals, so a restricted refinement model was used for all of them $(\mathrm{d}(\mathrm{M}-\mathrm{H}=1.59(1) \AA)$.

Crystal data for 2: $\mathrm{C}_{40} \mathrm{H}_{50} \mathrm{O}_{2} \mathrm{OsP}_{2} \cdot 0.5 \mathrm{CH}_{3} \mathrm{OH}, \mathrm{M}_{\mathrm{W}} 830.96$, orange, irregular block $(0.13 \times 0.11 \times 0.10)$, orthorhombic, space group Pbca, $a: 16.6453(13) \AA, b: 18.6334(15) \AA, c: 23.6385(19) \AA, V=$ 7331.7(10) $\AA^{3}, Z=8, Z^{\prime}=1, D_{\text {calc }}: 1.506 \mathrm{~g} \mathrm{~cm}^{-3}, \mathrm{~F}(000): 3368, \mathrm{~T}=$ $100(2) \mathrm{K}, \mu 3.601 \mathrm{~mm}^{-1} .56496$ measured reflections $\left(2 \theta: 3-58^{\circ}, \omega\right.$ scans $\left.0.3^{\circ}\right), 8952$ unique $\left(\mathrm{R}_{\text {int }}=0.0733\right)$; min. $/$ max. transm. Factors $0.710 / 0.862$. Final agreement factors were $\mathrm{R}^{1}=0.0541$ (6453 observed reflections, $\mathrm{I}>2 \sigma(\mathrm{I}))$ and $\mathrm{wR}^{2}=0.0919$; data/restraints/parameters $8952 / 1 / 439 ; \mathrm{GoF}=1.131$. Largest peak and hole 2.821 (close to osmium atom) and $-1.344 \mathrm{e} / \AA^{3}$.

Crystal data for 10: $\mathrm{C}_{37} \mathrm{H}_{50} \mathrm{O}_{2} \mathrm{OsP}_{2}, \mathrm{M}_{\mathrm{w}} 778.91$, orange, irregular block $(0.13 \times 0.08 \times 0.06)$, triclinic, space group $\mathrm{P} \overline{1}, a: 11.7401(14) \AA$, $b: 12.0479(14) \AA, c: 27.560(3) \AA, a: 78.724(2)^{\circ}, \beta: 83.870(2)^{\circ}, \gamma:$ 60.9790(10) ${ }^{\circ}, V=3342.6(7) \AA^{3}, Z=4, Z^{\prime}=2, \mathrm{D}_{\text {calc }}: 1.548 \mathrm{~g} \mathrm{~cm}^{-3}$, $F(000): 1576, T=100(2) \mathrm{K}, \mu 1.548 \mathrm{~mm}^{-1} .33626$ measured reflections $\left(2 \theta: 3-51^{\circ}, \omega\right.$ scans $\left.0.3^{\circ}\right), 12408$ unique $\left(R_{\text {int }}=0.0654\right)$; $\mathrm{min} . / \mathrm{max}$. transm. Factors $0.636 / 0.862$. Final agreement factors were $\mathrm{R}^{1}=0.0599$ (9138 observed reflections, $\left.\mathrm{I}>2 \sigma(\mathrm{I})\right)$ and $\mathrm{wR}^{2}=0.1369$; data/restraints/parameters $12408 / 22 / 792 ; \mathrm{GoF}=1.100$. Largest peak and hole 3.239 (close to osmium atoms) and $-2.415 \mathrm{e} / \AA^{3}$.
Crystal data for 13: $\mathrm{C}_{31} \mathrm{H}_{46} \mathrm{O}_{2} \mathrm{P}_{2} \mathrm{Ru}, \mathrm{M}_{\mathrm{W}}$ 613.69, red, irregular block $(0.15 \times 0.10 \times 0.02)$, orthorhombic, space group Pna2 ${ }_{1}, a$ : 19.813(3) $\AA, b: 9.9286(17) \AA, c: 31.283(5) \AA, V=6153.9(18) \AA^{3}, Z=8, Z^{\prime}=2$, $\mathrm{D}_{\text {calc }}: 1.325 \mathrm{~g} \mathrm{~cm}^{-3}, \mathrm{~F}(000): 2576, \mathrm{~T}=100(2) \mathrm{K}, \mu 0.638 \mathrm{~mm}^{-1} .58966$ measured reflections $\left(2 \theta: 3-53^{\circ}, \omega\right.$ scans $\left.0.3^{\circ}\right), 11646$ unique $\left(\mathrm{R}_{\text {int }}=\right.$ $0.0981)$; min./max. transm. Factors $0.569 / 0.745$. Final agreement factors were $\mathrm{R}^{1}=0.0595$ (8096 observed reflections, $\left.\mathrm{I}>2 \sigma(\mathrm{I})\right)$ and $\mathrm{wR}^{2}=0.1602$; data/restraints/parameters $11646 / 3 / 678$; Flack parameter 0.26(6); $\mathrm{GoF}=1.026$. Largest peak and hole 1.261 and $-0.766 \mathrm{e} /$ $\AA^{3}$.

Crystal data for 21: $\mathrm{C}_{28} \mathrm{H}_{42} \mathrm{O}_{2} \mathrm{OsP}_{2}, \mathrm{M}_{\mathrm{W}}$ 662.76, yellow, irregular block $(0.17 \times 0.16 \times 0.11)$, monoclinic, space group $\mathrm{P} 2{ }_{1} / \mathrm{c}, a$ : 10.770(3) $\AA, b: 16.065(4) \AA, c: 16.500(4) \AA, \beta: 103.089(4)^{\circ}, V=$ $2780.8(13) \AA^{3}, Z=4, Z^{\prime}=1, \mathrm{D}_{\text {calc }}: 1.583 \mathrm{~g} \mathrm{~cm}^{-3}, \mathrm{~F}(000): 1328, \mathrm{~T}=$ $100(2) \mathrm{K}, \mu 4.723 \mathrm{~mm}^{-1} .24464$ measured reflections $\left(2 \theta: 3-58^{\circ}, \omega\right.$ scans $\left.0.3^{\circ}\right), 7839$ unique $\left(\mathrm{R}_{\text {int }}=0.0573\right) ; \mathrm{min} . \mathrm{max}$. transm. Factors $0.656 / 0.842$. Final agreement factors were $\mathrm{R}^{1}=0.0433$ (5322 observed reflections, $\mathrm{I}>2 \sigma(\mathrm{I}))$ and $\mathrm{wR}^{2}=0.1046$; data/restraints/parameters 7839/2/314; $\mathrm{GoF}=0.959$. Largest peak and hole 2.946 (close to osmium atoms) and $-1.460 \mathrm{e} / \AA^{3}$.

\section{ASSOCIATED CONTENT}

\section{Supporting Information}

Figures containing ${ }^{1} \mathrm{H}$ NMR spectra (aromatic region) of the products of the reactions of complexes $\mathbf{1}$ and $\mathbf{4}$ with benzophenone and perdeuterated benzophenone, and a CIF giving crystallographic data for compounds $2, \mathbf{1 0}, \mathbf{1 3}$, and 21. This material is available free of charge via the Internet at http://pubs.acs.org.

\section{AUTHOR INFORMATION}

\section{Corresponding Author}

*E-mail:maester@unizar.es.

Notes

The authors declare no competing financial interest.

\section{ACKNOWLEDGMENT}

Financial support from the Spanish MINECO (Projects CTQ201452799-P and CTQ2014-51912-REDC), the DGA (E35) and the European Social Fund (FSE) is acknowledged. J.A. acknowledges support via a pre-doctoral fellowship from the DGA. P.P. acknowledges the Prof. H. J. Backer Foundation and the European Union Erasmus programme for their support.

\section{REFERENCES}

(1) (a) Shilov, A. E.; Shul 'pin, G. B. Chem. Rev. 1997, 97, 28792932. (b) Labinger, J. A.; Bercaw, J. E. Nature 2002, 417, 507-514 (c) Lersch, M.; Tilset, M. Chem. Rev. 2005, 105, 2471-2526. (d) Balcells, D.; Clot, E.; Eisenstein, O. Chem. Rev. 2010, 110, 749-823.

(2) (a) Mkhalid, I. A. I.; Barnard, J. H.; Marder, T. B.; Murphy, J. M.; Hartwig, J. F. Chem. Rev. 2010, 110, 890-931. (b) Lyons, T. W.; Sanford, M. S. Chem. Rev. 2010, 110, 1147-1169. (c) Kuhl, N.; Hopkinson, M. N.; Wencel-Delord, J.; Glorius, F. Angew. Chem. Int. Ed. 2012, 51, 10236-10254.

(3) Alabau, R. G.; Eguillor, B.; Esler, J.; Esteruelas, M. A.; Oliván, M.; Oñate, E.; Tsai, J.-Y.; Xia, C. Organometallics 2014, 33, 55825596.

(4) (a) Colby, D. A.; Bergman, R. G.; Ellman, J. A. Chem. Rev. 2010, 110, 624-655. (b) Ros, A.; Fernández, R.; Lassaletta, J. M Chem. Soc. Rev. 2014, 43, 3229-3243.

(5) (a) Ackermann, L. Chem. Rev. 2011, 111, 1315-1345. (b) Engle, K. M.; Mei, T.-S.; Wasa, M.; Yu, J.-Q. Acc. Chem. Res. 2012, $45,788-802$.

(6) (a) Kakiuchi, F.; Murai, S. Top. Organomet. Chem. 1999, 3, 4779 (b) Kakiuchi, F.; Murai, S. Acc. Chem. Res. 2002, 35, 826-834. 
(7) (a) Kakiuchi, F.; Matsuura, Y.; Kan, S.; Chatani, N. J. Am. Chem. Soc. 2005, 127, 5936-5945. (b) Ueno, S.; Mizushima, E.; Chatani, N.; Kakiuchi, F. J. Am. Chem. Soc. 2006, 128, 16516-16517. (c) Gandeepan, P.; Parthasarathy, K.; Cheng, C.-H. J. Am. Chem. Soc. 2010, 132, 8569-8571. (d) Wencel-Delord, J.; Nimphius, C.; Patureau, F. W.; Glorius, F. Angew. Chem. Int. Ed. 2012, 51, 22472251. (e) Zhao, D.; Li, X.; Han, K.; Li, X.; Wang, Y. J. Phys. Chem. A 2015, 119, 2989-2997.

(8) See for example: (a) Esteruelas, M. A.; García-Raboso, J.; Oliván, M. Organometallics 2011, 30, 3844-3852. (b) Bajo, S.; Esteruelas, M. A.; López, A. M.; Oñate, E. Organometallics 2011, 30, 5710-5715. (c) Crespo, O.; Eguillor, B.; Esteruelas, M. A.; Fernández, I.; García-Raboso, J.; Gómez-Gallego, M.; Martín-Ortiz, M.; Oliván, M.; Sierra, M. A. Chem. Commun. 2012, 48, 5328-5330. (d) Bajo, S.; Esteruelas, M. A. López, A. M.; Oñate, E. Organometallics 2014, 33, 1851-1858. (e) Bolaño, T.; Esteruelas, M. A.; Fernández, I.; Oñate, E.; Palacios, A.; Tsai, J.-Y.; Xia, C. Organometallics 2015, 34, 778789 .

(9) (a) Barrio, P.; Castarlenas, R.; Esteruelas, M. A.; Lledós, A.; Maseras, F.; Oñate, E.; Tomàs, J. Organometallics 2001, 20, 442-452. (b) Barrio, P.; Castarlenas, R.; Esteruelas, M. A.; Oñate, E. Organometallics 2001, 20, 2635-2638. (c) Esteruelas, M. A.; Lledós, A.; Oliván, M.; Oñate, E.; Tajada, M. A.; Ujaque, G. Organometallics 2003, 22, 3753-3765. (d) Esteruelas, M. A.; Hernández, Y.; López, A. M.; Oliván, M.; Oñate, E. Organometallics 2005, 24, 5989-6000. (e) Eguillor, B.; Esteruelas, M. A.; Oliván, M.; Oñate, E. Organometallics 2005, 24, 1428-1438. (f) Buil, M. L.; Esteruelas, M. A.; Garcés, K.; Oliván, M.; Oñate, E. Organometallics 2008, 27, 4680-4690.

(10) (a) Eguillor, B.; Esteruelas, M. A.; Oliván, M.; Oñate, E. Organometallics 2004, 23, 6015-6024. (b) Esteruelas, M. A.; Hernández, Y. A.; López, A. M.; Oliván, M.; Rubio, L. Organometallics 2008, 27, 799-802.

(11) Eguillor, B.; Esteruelas, M. A.; García-Raboso, J.; Oliván, M.; Oñate, E. Organometallics 2009, 28, 3700-3709.

(12) (a) Asensio, G.; Cuenca, A. B.; Esteruelas, M. A.; MedioSimón, M.; Oliván, M.; Valencia, M. Inorg. Chem. 2010, 49, 86658667. (b) Esteruelas, M. A.; Honczek, N.; Oliván, M.; Oñate, E.; Valencia, M. Organometallics 2011, 30, 2468-2471. (c) Esteruelas, M. A.; Oliván, M.; Vélez, A. Inorg. Chem. 2013, 52, 5339-5349. (d) Alós, J.; Bolaño, T.; Esteruelas, M. A.; Oliván, M.; Oñate, E.; Valencia, M. Inorg. Chem. 2013, 52, 6199-6213. (e) Esteruelas, M. A.; Oliván, M.; Vélez, A. Inorg. Chem. 2013, 52, 12108-12119. (f) Alós, J.; Bolaño, T.; Esteruelas, M. A.; Oliván, M.; Oñate, E.; Valencia, M. Inorg. Chem. 2014, 53, 1195-1209. (g) Esteruelas, M. A.; Oliván, M.; Vélez, A. DOI: 10.1021/acs.organomet.5b00176.

(13) (a) Zuideveld, M. A.; Swennenhuis, B. H. G.; Boele, M. D. K.; Guari, Y.; van Strijdonck, G. P. F.; Reek, J. N. H.; Kamer, P. C. J.; Goubitz, K.; Fraanje, J.; Lutz, M.; Spek, A. L.; van Leeuwen, P. W. N. M. J. Chem. Soc., Dalton Trans. 2002, 2308-2317. (b) van der Vlugt, J. I.; Sablong, R.; Mills, A. M.; Kooijman, H.; Spek, A. L.; Meetsma, A.; Vogt, D. Dalton Trans. 2003, 4690-4699. (c) Fox, D. J.; Duckett, S. B.; Flaschenriem, C.; Brennessel, W. W.; Schneider, J.; Gunay, A.; Eisenberg, R. Inorg. Chem. 2006, 45, 7197-7209. (d) Grushin, V. V.; Marshall, W. J. J. Am. Chem. Soc. 2006, 128, 1264412645. (e) Deb, B.; Borah, B. J.; Sarmah, B. J.; Das, B.; Dutta, D. K. Inorg. Chem. Commun. 2009, 12, 868-871. (f) Ledger, A. E. W.; Slatford, P. A.; Lowe, J. P.; Mahon, M. F.; Whittlesey, M. K.; Williams, J. M. J. Dalton Trans. 2009, 716-722. (g) Pontiggia, A. J.; Chaplin, A. B.; Weller, A. S. J. Organomet. Chem. 2011, 696, 28702876. (h) Guard, L. M.; Ledger, A. E. W.; Reade, S. P.; Ellul, C. E.; Mahon, M. F.; Whittlesey, M. K. J. Organomet. Chem. 2011, 696, 780-786. (i) Dallanegra, R.; Chaplin, A. B.; Weller, A. S. Organometallics 2012, 31, 2720-2728.

(14) See for example: (a) Batuecas, M.; Esteruelas, M. A.; GarcíaYebra, C.; Oñate, E. Organometallics 2010, 29, 2166-2175. (b) Varela-Fernández, A.; García-Yebra, C.; Valera, J. A.; Esteruelas, M. A.; Saá, C. Angew. Chem. Int. Ed. 2010, 49, 4278-4281. (c) Collado, A.; Esteruelas, M. A.; López, F.; Mascareñas, J. L.; Oñate, E.; Trillo, B. Organometallics 2010, 29, 4966-4974. (d) Collado, A.; Esteruelas, M. A.; Oñate, E. Organometallics 2011, 30, 1930-1941. (e) Collado,
A.; Esteruelas, M. A.; Gulías, M.; Mascareñas, J. L.; Oñate, E. Organometallics 2012, 31, 4450-4458.

(15) For some relevant papers, see: C,C,C-ligands: (a) Chung, L.H.; Chan, S.-C.; Lee, W.-C.; Wong, C.-Y. Inorg. Chem. 2012, 51, 8693-8703. C,N,C-ligands: (b) Wong, C.-Y.; Lai, L.-M.; Pat, P.-K.; Chung, L.-H. Organometallics 2010, 29, 2533-2539. (c) Esteruelas, M. A.; Fernández, I.; Herrera, A.; Martín-Ortiz, M.; MartínezÁlvarez, R.; Oliván, M.; Oñate, E.; Sierra, M. A.; Valencia, M. Or ganometallics 2010, 29, 976-986. (d) Chung, L.-H.; Cho, K.-S.; England, J.; Chan, S.-C.; Wieghardt, K.; Wong, C.-Y. Inorg. Chem. 2013, 52, 9885-9896. C,N,N-ligands: (e) Baratta, W.; Benedetti, F.; Del Zotto, A.; Fanfoni, L.; Felluga, F.; Magnolia, S.; Putignano, E.; Rigo, P. Organometallics 2010, 29, 3563-3570. C,N,O-ligands: (f) Gupta, P.; Butcher, R. J.; Bhattacharya, S. Inorg. Chem. 2003, 42, 5405-5411. (g) Castarlenas, R.; Esteruelas, M. A.; Oñate, E. Organometallics 2007, 26, 3082-3084. P,C,P-ligands: (h) Wen, T. B.; Cheung, Y. K.; Yao, J.; Wong, W.-T.; Zhou, Z. Y.; Jia, G. Organometallics 2000, 19, 3803-3809. (i) Gusev, D. G.; Dolgushin, F. M.; Antipin, M. Y. Organometallics 2001, 20, 1001-1007. (j) Gauvin, R. M.; Rozenberg, H.; Shimon, L. J. W.; Milstein, D. Organometallics 2001, 20, 1719-1724. (k) Liu, S. H.; Lo, S. T.; Wen, T. B.; Williams, I. D.; Zhou, Z. Y.; Lau, C. P.; Jia, G. Inorg. Chim. Acta 2002, 334, 122-130. (1) Gusev, D. G.; Maxwell, T.; Dolgushin, F. M.; Lyssenko, M.; Lough, A.J. Organometallics 2002, 21, 1095 1100. (m) Gusev, D. G.; Lough, A. J. Organometallics 2002, 21, 2601-2603. (n) Wen, T. B.; Zhou, Z. Y.; Jia, G. Organometallics 2003, 22, 4947-4951. (o) Gusev, D. G.; Fontaine, F.-G.; Lough, A. J.; Zargarian, D. Angew. Chem. Int. Ed. 2003, 42, 216-219. (p) Wen, T. B.; Zhou, Z. Y.; Jia, G. Angew. Chem. Int. Ed. 2006, 45, 5842-5846. (q) Gauvin, R. M.; Rozenberg, H.; Shimon, L. J. W.; Ben-David, Y.; Milstein, D. Chem. Eur. J. 2007, 13, 1382-1393. (r) Kuznetsov, V. F.; Gusev, D. G. Organometallics 2007, 26, 5661-5666. P,N,P-ligands: (s) Jia, G.; Lee, H. M.; Williams, I. D.; Lau, C. P.; Chen, Y. Organometallics 1997, 16, 3941-3949. (t) Liu, S. H.; Lo, S. T.; Wen, T. B.; Zhou, Z. Y.; Lau, C. P.; Jia, G. Organometallics 2001, 20, $667-$ 672. (u) Lee, J.-H.; Fan, H.; Pink, M.; Caulton, K. G. New J. Chem. 2007, 31, 838-840. (v) Lee, J.-H.; Pink, M.; Tomaszewski, J.; Fan, H.; Caulton, K. G. J. Am. Chem. Soc. 2007, 129, 8706-8707. (w) Tsvetkov, N.; Fan, H.; Caulton, K. G. Dalton Trans. 2011, 40, 1105-1110. (x) Spasyuk, D.; Smith, S.; Gusev, D. G. Angew. Chem. Int. Ed. 2012 , 51, 2772-2775. N,N,N-ligands: (y) Esteruelas, M. A.; Masamunt, A. B.; Oliván, M.; Oñate, E.; Valencia, M. J. Am. Chem. Soc. 2008, 130, 11612-11613. (z) Müller, A. L.; Wadepohl, H.; Gade, L. H. Organometallics 2015, 34, 2810-2818.

(16) (a) Lee, J.-H.; Pink, M.; Caulton, K. G. Organometallics 2006, 25, 802-804. (b) Gruver, B. C.; Adams, J. J.; Arulsamy, N.; Roddick, D. M. Organometallics 2013, 32, 6468-6475.

(17) See for example: (a) Zhang, X.; Kanzelberger, M.; Emge, T. J.; Goldman, A. S. J. Am. Chem. Soc. 2004, 126, 13192-13193. (b) Feller, M.; Karton, A.; Leitus, G.; Martin, J. M. L.; Milstein, D. J. Am. Chem. Soc. 2006, 128, 12400-12401. (c) Bernskoetter, W. H.; Hanson, S. K.; Buzak, S. K.; Davis, Z.; White, P. S.; Swartz, R.; Goldberg, K.; Brookhart, M. J. Am. Chem. Soc. 2009, 131, 86038613. (d) Choi, J.; Choily, Y.; Zhang, X.; Emge, T. J.; KroghJespersen, K.; Goldman, A. S. J. Am. Chem. Soc. 2009, 131, $15627-$ 15629. (e) Whited, M. T.; Zhu, Y.; Timpa, S. D.; Chen, C.-H.; Foxman, B. M.; Ozerov, O. V.; Grubbs, R. H. Organometallics 2009, 28, 4560-4570. (f) Conde, A.; Fandos, R.; Hernández, C.; Otero, A.; Rodriguez, A. Chem. Eur. J. 2010, 16, 12074-12078. (g) Albrecht, M.; Lindner, M. M. Dalton Trans. 2011, 40, 8733-8744. (h) Fu, R.; Bercaw, J. E.; Labinger, J. A. Organometallics 2011, 30, 6751-6765. (i) Zhu, Y.; Smith, D. A.; Herbert, D. E.; Gatard, S.; Ozerov, O. V. Chem. Commun. 2012, 48, 218-220. (j) Kundu, S.; Choi, J.; Wang, D. Y.; Choliy, Y.; Emge, T. J.; Krogh-Jespersen, K.; Goldman, A. S. J. Am. Chem. Soc. 2013, 135, 5127-5143. (k) Allen, K. E.; Heinekey, D. M.; Goldman, A. S.; Goldberg, K.I. Organometallics 2013, 32, 1579 1582. (1) Gunanathan, C.; Milstein, D. Chem. Rev. 2014, 114, 12024 12087. (m) Coetzee, J.; Eastham, G. R.; Slawin, A. M. Z.; ColeHamilton, D. J. Dalton Trans. 2015, 44, 1585-1591.

(18) Matsubara, T.; Koga, N.; Musaev, D. G.; Morokuma, K. Organometallics 2000, 19, 2318-2329. 
(19) Eguillor, B.; Esteruelas, M. A.; Oliván, M.; Puerta, M. Organometallics 2008, 27, 445-450.

(20) (a) Selmeczy, A. D.; Jones, W. D.; Partridge, M. G.; Perutz, R. N. Organometallics 1994, 13, 522-532. (b) Renkema, K. B.; Bosque, R.; Streib, W. E.; Maseras, F.; Eisenstein, O.; Caulton, K. G. J. Am. Chem. Soc. 1999, 121, 10895-10907. (c) Carbó, J. J.; Eisenstein, O.; Higgitt, C. L.; Klahn, A. H.; Maseras, F.; Oelckers, B.; Perutz, R. N. J. Chem. Soc., Dalton Trans. 2001, 1452-1461. (d) Clot, E.; Besora, M.; Maseras, F.; Mégret, C.; Eisenstein, O.; Oelckers, B.; Perutz, R. N. Chem. Commun. 2003, 490-491. (e) Clot, E.; Oelckers, B.; Klahn, A. H.; Eisenstein, O.; Perutz, R. N. Dalton Trans. 2003, 4065-4074. (f) Hatnean, J. A.; Beck, R.; Borrelli, J. D.; Johnson, S. A. Organometallics 2010, 29, 6077-6091.

(21) (a) Liu, W.; Welch, K.; Trindle, C. O.; Sabat, M.; Myers, W. H.; Harman, W. D. Organometallics 2007, 26, 2589-2597. (b) Schaub, T.; Fischer, P.; Steffen, A.; Braun, T.; Radius, U.; Mix, A. J. Am. Chem. Soc. 2008, 130, 9304-9317. (c) Johnson, S. A.; Huff, C. W.; Mustafa, F.; Saliba, M. J. Am. Chem. Soc. 2008, 130, 1727817280. (d) Amii, H.; Uneyama, K. Chem. Rev. 2009, 109, 2119-2183. (e) Clot, E.; Eisenstein, O.; Jasim, N.; Macgregor, S. A.; McGrady, J. E.; Perutz, R. N. Acc. Chem. Res. 2011, 44, 333-348. (f) Johnson, S. A.; Mroz, N. M.; Valdizon, R.; Murray, S. Organometallics 2011, 30, 441-457. (g) Li, B. Z.; Qian, Y. Y.; Liu, J.; Chan, K. S. Organometallics 2014, 33, 7059-7068. (h) Kalläne, S. I.; Teltewskoi, T.; Braun, T.; Braun, B. Organometallics 2015, 34, 1156-1169.

(22) (a) Evans, M. E.; Burke, C. L.; Yaibuathes, S.; Clot, E.; Eisenstein, O.; Jones, W. D. J. Am. Chem. Soc. 2009, 131, 13464-13473. (b) Clot, E.; Mégret, C.; Eisenstein, O.; Perutz, R. N. J. Am. Chem. Soc. 2009, 131, 7817-7827. (c) Tanabe, T.; Brennessel, W. W.; Clot, E.; Eisenstein, O.; Jones, W. D. Dalton Trans. 2010, 39, 1049510509.

(23) Xu, X.; Jia, J.; Sun, H.; Liu, Y.; Xu, W.; Shi, Y.; Zhang, D.; Li, X. Dalton Trans. 2013, 42, 3417-3428.

(24) Zheng, T.; Sun, H.; Ding, J.; Zhang, Y.; Li, X. J. Organomet. Chem. 2010, 695, 1873-1877.

(25) For the insertion of the C-C double bond of methyl vinyl ketone into an Os-H bond, see for example: (a) Esteruelas, M. A.; Lahoz, F. J.; López, J. A.; Oro, L. A.; Schlünken, C.; Valero, C.; Werner, H. Organometallics 1992, 11, 2034-2043. For an osmiummediated activation of a terminal $\mathrm{C}\left(\mathrm{sp}^{2}\right)-\mathrm{H}$ bond of methyl vinyl ketone, see for example: (b) Edwards, A. J.; Elipe, S.; Esteruelas, M. A.; Lahoz, F. J.; Oro, L. A.; Valero, C. Organometallics 1997, 16, 3828-3836.

(26) (a) Gong, L.; Lin, Y.; Wen, T. B.; Xia, H. Organometallics 2009, 28, 1101-1111. (b) Lin, Y.; Gong, L.; Xu, H.; He, X.; Wen, T. B.; Xia, H. Organometallics 2009, 28, 1524-1533. (c) Esteruelas, M. A.; Larramona, C.; Oñate, E. Organometallics 2013, 82, 2567-2575. (d) Liu, B.; Zhao, Q.; Wang, H.; Zeng, B.; Cao, X.; Xia, H. Sci. China Chem. 2013, 56, 1105-1111. (e) Zhao, Q.; Cao, X.-Y.; Wen, T. B.; Xia, H. Chem. Asian J. 2013, 8, 269-275. (f) Cao, X.-Y.; Zhao, Q.; Lin, Z.; Xia, H. Acc. Chem. Res. 2014, 47, 341-354. (g) Chen, J.; Huang, Z.-A.; Hua, Y.; Zhang, H.; Xia, H. Organometallics 2015, 34, 340-347. (h) Tsui, W.-K.; Chung, L.-H.; Tsang, W-H.; Yeung, C.-F.; Chiu, C.-H.; Lo, H.-S.; Wong, C.-Y. Organometallics 2015, 34, 10051012 .

(27) (a) Stone, K. C.; Jamison, G. M.; White, P. S.; Templeton, J. L. Organometallics 2003, 22, 3083-3095. (b) Li, X.; Appelhans, L. N.; Faller, J. W.; Crabtree, R. H. Organometallics 2004, 23, 33783387. (c) Li, X.; Vogel, T.; Incarvito, C. D.; Crabtree, R. H. Organometallics 2005, 24, 62-76.

(28) (a) Olsen, E. P. K.; Madsen, R. Chem. Eur. J. 2012, 18, 16023-16029. (b) Roa, A. E.; Salazar, V.; López-Serrano, J.; Oñate, E.; Paneque, M.; Poveda, M. L. Organometallics 2012, 31, 716-721. (c) Olsen, E. P. K.; Singh, T.; Harris, P.; Andersson, P. G.; Madsen, R. J. Am. Chem. Soc. 2015, 137, 834-842.

(29) Garralda, M. A. Dalton Trans. 2009, 3635-3645.

(30) Willis, M. C. Chem. Rev. 2010, 110, 725-748.

(31) For examples of ortho-C-H bond activation see references 10a and $10 \mathrm{~b}$, whereas for examples of $\mathrm{OC}-\mathrm{H}$ cleavage see: Barrio, P.; Esteruelas, M. A.; Oñate, E. Organometallics 2004, 23, 1340-1348.
(32) Blessing, R. H. Acta Crystallogr. 1995, A51, 33-37. SADABS: Area-Detector absorption correction; Bruker-AXS: Madison, WI, 1996.

(33) SHELXTL Package, v. 6.10; Bruker-AXS: Madison, WI, 2000. Sheldrick, G. M. Acta Crystallogr. 2008, A64, 112-122. 


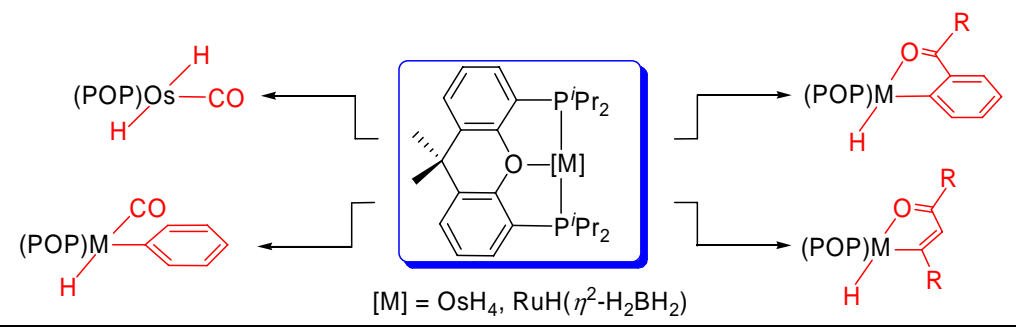

